\title{
Groundwater Chemistry at Yucca Mountain, Nevada, and Vicinity
}

\author{
Jerry F. Kerrisk
}

\section{DISCLAIMER}

\begin{abstract}
This report was prepared as an account of work sponsored by an agency of the United States Government. Neither the United States Government nor any agency thereof, nor any of their employees, makes any wareanty, express or implied, or assumes any legal liability or responsibility for ti,e accuracy, completeness, or usefulness of any information, apparatus, product, or p:ccess disclosed, or represents that its use would not infringe privately owned rights. Relerence herein to any specific commercial product, process, or service by trade name, trademark, manufacturer, or otherwise does not necessarily constitute or imply its endorsement, recommendation, or favoring by the United States Government or any agency thereof. The views and opinions of authors expressed herein do not necessarily state or reflect those of the United States Government or any agency thereof.
\end{abstract}

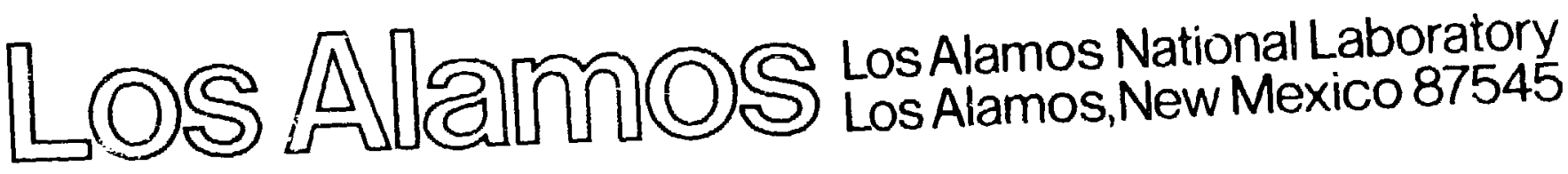




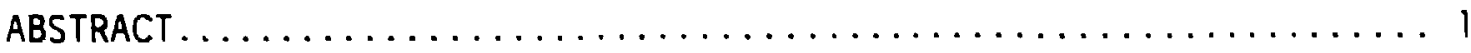

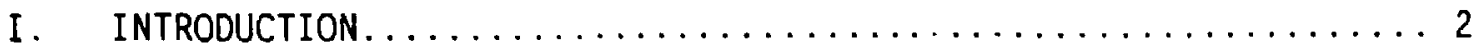

II. PREVIOUS WORK $\ldots \ldots \ldots \ldots \ldots \ldots \ldots \ldots \ldots \ldots \ldots \ldots \ldots \ldots \ldots \ldots \ldots \ldots \ldots$

III. YUCCA MOUNTAIN WELLS $\ldots \ldots \ldots \ldots \ldots \ldots \ldots \ldots \ldots \ldots \ldots \ldots \ldots \ldots \ldots$

IV. SOURCES OF GROUNDWATER $\ldots \ldots \ldots \ldots \ldots \ldots \ldots \ldots \ldots \ldots \ldots \ldots$

V. ACTIVE CHEMICAL AND PHYSICAL PROCESSES $\ldots \ldots \ldots \ldots \ldots \ldots \ldots \ldots \ldots$

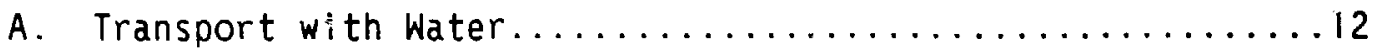

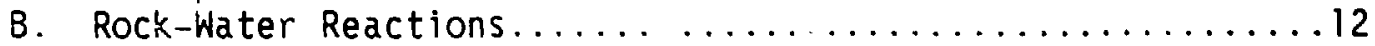

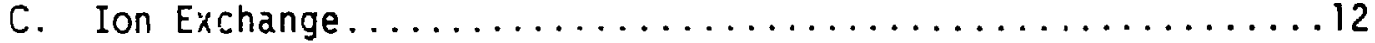

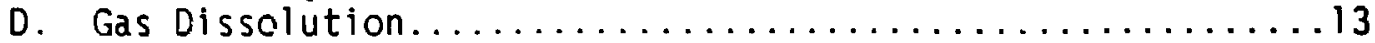

E. Mixing of Different Water Compositions................13

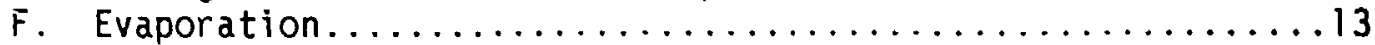

VI. IMPORTANT GROUNDWATER COMPOSITIONAL VARIABLES

AND RELATIONS AMONG THESE VARIABLES $\ldots \ldots \ldots \ldots \ldots \ldots \ldots \ldots \ldots$

A. Major Species and Variables..................... 4

B. Isotopic Data....................................

C. Other Species and Variables........................

D. Relations with Location or Depth...................46

VII. CONTROLS ON GROUNDWATER COMPOSITION................... 52

A. Control of Cation Content, Aqueous Silica Content,

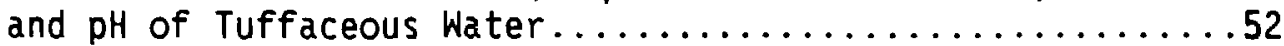

B. Control of Carbonate Content of Tuffaceous Water.........55

C. Control of Chloride and Sulfate Content of Tuffaceous Water.............................64

D. Control of the Redox State of the Water.............65

E. Control of Gther Compositional Variables of

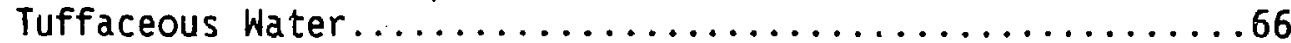

F. Controls on Unsaturated-Zone Water Composition...........67

VIII. IMPLICATIONS FOR RADIONUCLIDE TRANSPORT $\ldots \ldots \ldots \ldots \ldots \ldots \ldots$

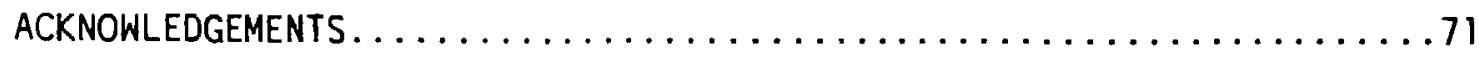

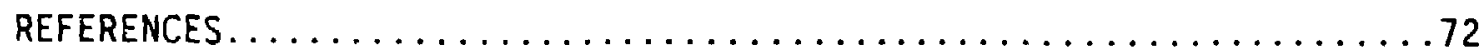

APPENDIX A: WATER CHEMISTRY DATA........................ 77

APPENDIX B: IMPORTANCE OF RADIONUCLIDE TRANSPORT BY

PARTICULATES ENTRAINED Îi FLOWING GROUNDWATERS ......114 


\section{TABLES}

I. Wells at Yucca Mountain and Vicinity....................

II. Water Sampling Locations....................... 6

III. Variation of Water Properties with Depth................50

IV. Carbon Model Parameters Used in Figures 26 and $27 \ldots \ldots \ldots \ldots 61$ 
1. Area map of Yucca Mountain and vicinity with well locations.... 3

2. Sodiuin content as a function of total carbonate content.

(a) All sampling locations (see Table II for meaning of

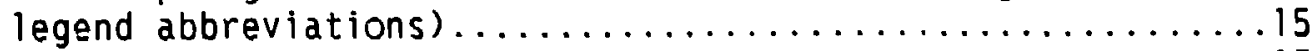

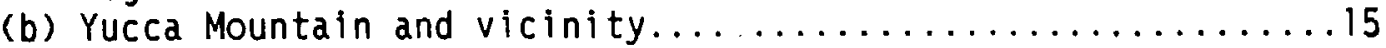

3. Calcium content as a function of total carbonate content.

(a) All sampling locations (see Table II for meaning of

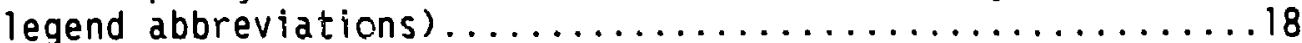

(b) Yucca Mountain arid vicinity..................... 18

4. Teinary diagram of relative sodium, calcium, and potassium content.

(a) All sampling locations (see Table II for meaning of

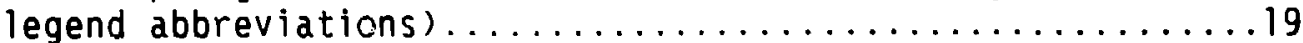

(b) Yucca Mountain and vicinity.......................

5. $\mathrm{Na} /(\mathrm{Na}+\mathrm{Ca}+\mathrm{K})$ as a function of $\mathrm{pH}$ at Yucca Mountain and vicinity. Solid lines represent calculated results froin Kerrisk (1983).

6. The $\log _{10}$ (calcium content) as a function of $\mathrm{pH}$ at Yucca Mountain and vicinity.

7. The $\mathrm{pH}$ as a function of total carbonare content at Yucca Mountain and vicinity.

8. The $\log _{10}$ (carbon dioxide pressure) as a function of $\mathrm{pH}$.

(a) All sampling locations (see Table II for meaning of

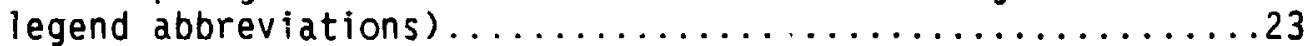

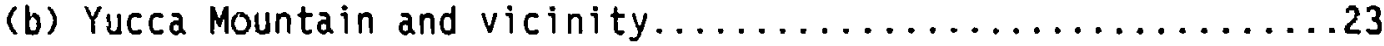

9. The $\log _{10}$ (carbon dioxide pressure) as a function of total carbonate content at Yucca Mountain and vicinity............25

10. Calcite $\log _{10}(Q / K)$ as a function of $\mathrm{pH}$ at Yucca Mountain

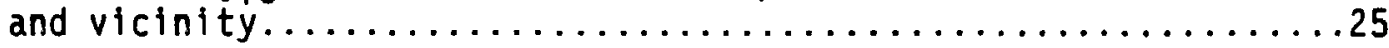

11. The (chloride + sulfate) content as a function of total carbonate content.

(a) All sampling locations (see Table II for meaning of

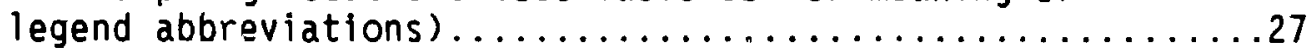

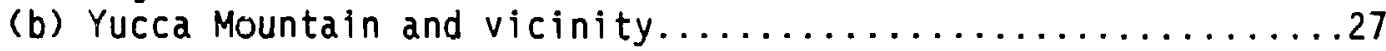

12. Sulfate and chloride contents as a function of total carbonate content at Yucca Mountain and vicinity.

(a) Sulfate content 25 a function of total carbonate.........29

(b) Chloride content as a function of total carbonate........29 
13. Sulfate content as a function of chloride content

(see Table II for meaning of legend abbreviations).

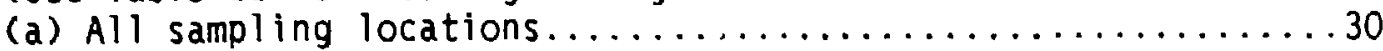

(b) Expanded plot of region near the origin.................

14. Percentage of modern carbon as a function of total carbonate content.

(a) All sampling locations (see Table II for meaning of

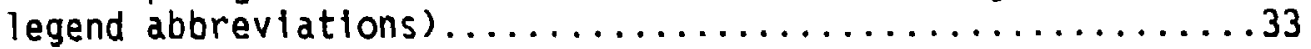

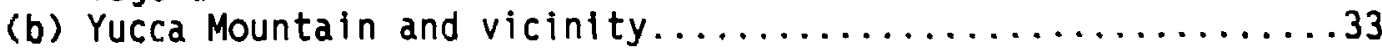

15. $\delta 13 \mathrm{C}$ as a function of total carbonate content.
(a) All sampling locations (see Table II for meaning of

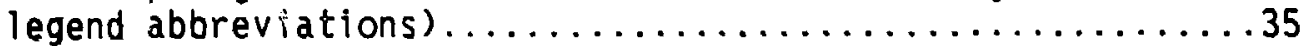

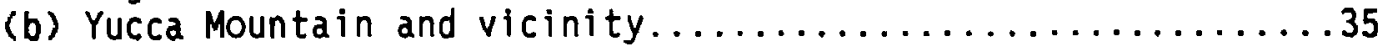

16. The $\mathrm{pH}$ as a function of the percentage of modern carbon and $\delta^{13} \mathrm{C}$ at Yucca Mountain and vicinity.

(a) $\mathrm{pH}$ as a function of the percentage of modern carbon.........37

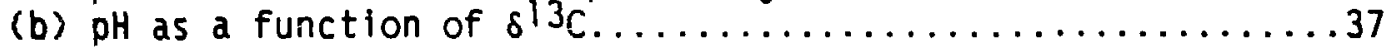

17. $\delta D$ as a function of $\delta^{180}$.

(a) All sampling locations (see Table II for meaning of

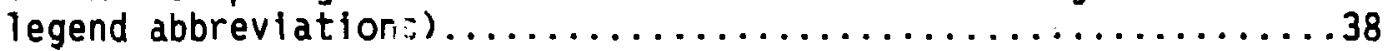

(b) Yucca Mountain and vicinity......................

18. $\delta 0$ as a function of the percentage of modern carbon and total carbonate content at Yucca Mountain and vicinity.

(a) $S D$ as a function of the percentage of modern carbon........40

(b) $\delta D$ as a function of total carbonate content............40

19. Nitrate content as a function of the percentage of modern carbon and total carbonate content at Yucca Mountain and vicinity.

(a) Nitrate content as a function of the percentage of modern carbon................................42

(b) Nitrate content as a function of total carbonate content...42

20. Fluoride content as a function of sodium content and total carbonate at Yucca Mountain and vicinity.

(a) Fluoride content as a function of sodium content..........44

(b) Fluoride content as a function of total carbonate content.

21. Water temperature as a function of the percentage of modern carbon and total carbonate content at Yucca Mountain and vicinity.

(a) Water temperature as a function of the percentage of modern carbon...................................47

(b) Water temperature as a function of total carbonate.......47

22. $\mathrm{Na} /(\mathrm{Na}+\mathrm{Ca}+\mathrm{K})$ as a function of location for wells near Yucca Mountain. 
23. Calcium content as a function of sodium content at

Yucca Mountain and vicinity.........................48

24. Total carbonate content as a function of location for

wells near Yucca Mountain............................49

25. Ternary diagrams of relative sodium, calclum, and potassium content at Rainier Mesa.

(a) Surface water and pore water (Benson 1976).............53

(b) Surface water and fracture water (Henne 1982)...........53

26. Percentage of modern carbon as a function of total carbonate content at Yucca Mountain with carbon-mcdel prediction

(see Table IV for solid and dashed curve definitions).........60

27. $\delta^{13} \mathrm{C}$ as a function of total carbonate content at

Yucca Mountain with carbon-model prediction (see Table IV

for solid and dashed curve definitions)...................60

28. $S D$ as a function of apparent age and carbon-model age at Yucca Mountain.

(a) $S D$ as a function of apparent age.....................63

(b) $S D$ as a function of carbon-model age..................63 


\title{
GROUNDWATER CHEMISTRY AT YUCCA MOUNTAIN, NEVADA, AND VICINITY
}

\section{by}

Jerry F. Kerrisk

\begin{abstract}
The chemistry of groundwater at Yucca Mounta in and vicinity has been reviewed and compared with the chemistry of water from the Nevada Test Site and surrounding areas such as the Amargosa Desert and Oasis Valley. Sodium is the primary cation and carbonate is the primary anion in vater from the saturated zone of the tuffaceous aquifer at Yucca Mountain. Other major cations present are calcium, potassium, and magnesium; other major anions are sulfate and chloride, with lesser quantities of fiuoride and nitrate. Aqueous silica is also present. The primary purpose of this review was to survey water-composition data and look for relations among the compositional variables that could provide insight into the processes that controi the composition and would ultimately affect radionuclide transport. The following conclusions were inferred frow the review. Major cation concentrations are controlled by rock dissolution and mineral precipitation reactions as well as by cation exchange with existing minerals. Aqueous carbonate initially comes from atmospheric and soil-zone carbon dioxide, but there is evidence at Yucca Mountain that carbon dioxide in the gas phase of the unsaturated zone supplies additional carbonate to saturated-zone water in the tuffaceous aquifer as mineral dissolution and precipitation reactions raise the $\mathrm{pH}$ of the water. This combination is effectively mineral dissolution and precipitation in a system that is open with respect to carbon dioxide. A carbon model for this process is discussed; one conclusion of the model is that the true age of vater that has obtained significant amounts of carbonate from the gas phase of the unsaturated zone is older than its apparent age. The primary source of aqueous chloride and sulfate
\end{abstract}


is probably from precipitation; there does not appear to be any mineralogical controls on these species at Yucca Mountain. There is some evidence that water in the deep saturated zone at Yucca Mountain may be reducing; this conclusion would be difficult to prove with existing data. Water near the static-water level is oxldizing. Water in the western part of Yucca Mountain is lower in calcium than water to the east. Carbonate and fluoride tend to be more concentrated in the water in the southwestern part of Yucca Mountain. The implications of these conclusions for radionuclide transport primarily reflect the range of water compositions that could be encountered at Yucca Mountain. Oxidizing conditions, and carbonate and fluoride complexes, will have the largest impact on solubility and speciation. There are not enough data avallable at this time to discuss the processes that control unsaturated-zone water compositions at Yucca Mountain.

\section{INTRODUCTION}

The Nevada Nuclear Waste Storage Investigations (NNWSI) Project is studying a site at Yucca Mountain in southern Nevada as a potential nuclear waste repository. The site is located on the southwestern edge of the Nevada Test Site (NTS) and on adjacent US Bureau of Land Management land and land controlled by the US AIr Force (see Fig. 1). The Topopah Spring Member tuff in the unsaturated zone of Yucca Mountain has been selected as the candidate rock unit for the repository. Waste-element transport in water that moves through the waste-storage area and toward the environment is considered the most likeiy mechanism for release of most waste elements. To evaluate the importance of this mechanism, site-characterization information is required about water flow paths, water fluxes, and water chemistry. This report discusses water chemistry at Yucca Mountain and in nearby areas. Water chemistry is an important parameter for waste-element transport because the solubility, speciation, and sorption of waste elements on local minerals all depend on water chemistry. Water chemistry can also affect the composition and stability of the minerals in contact with the water. Questions concerning water fluxes and flow paths are being addressed by the US Geological survey (USGS) in another part of the NNWSI Project (Montazer and Wilson 1984; Wadde 11 et al. 1984). 


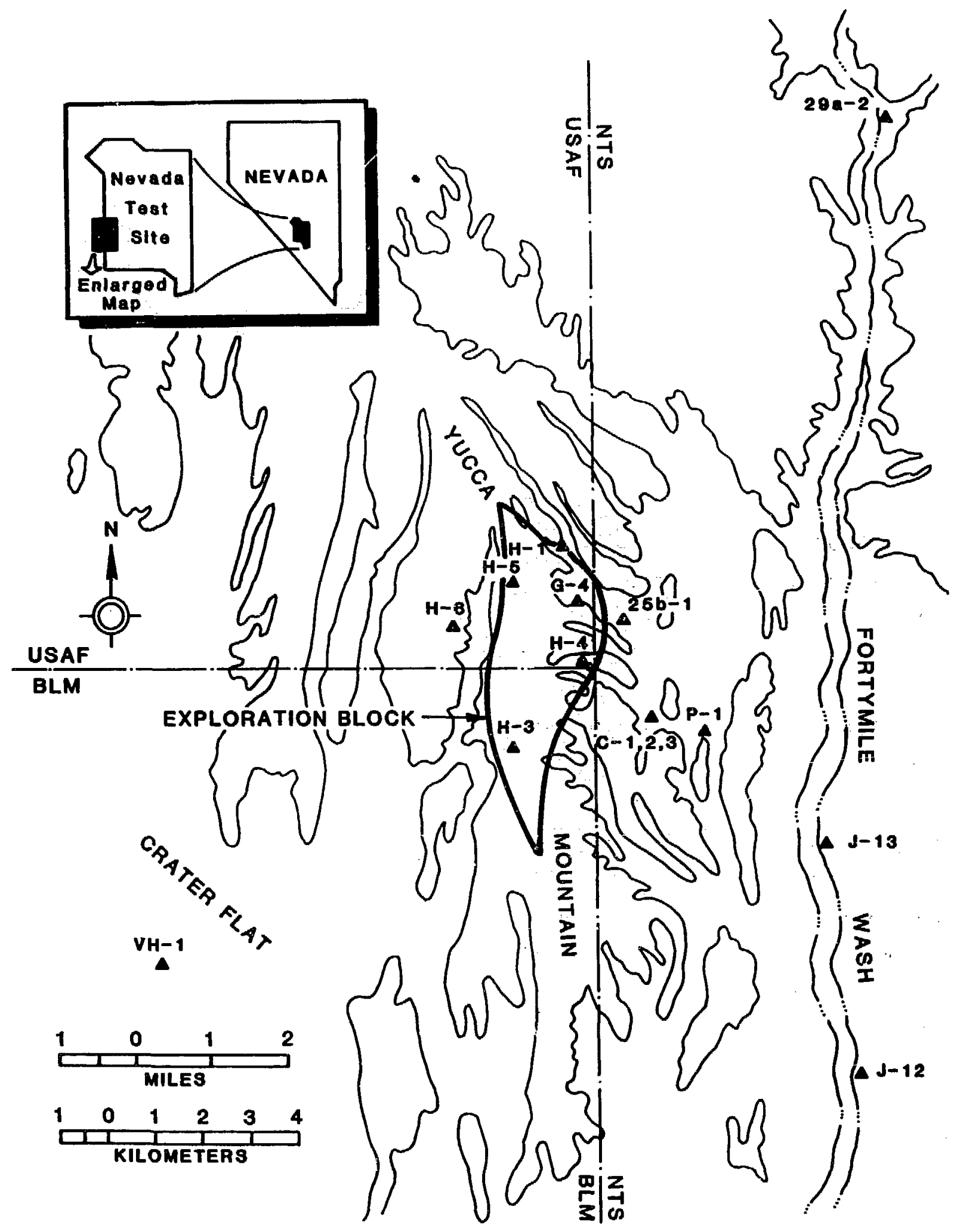

Fig. 1. Area map of Yucca Mountain and vicinity with well locations. 
The Yucca Mountain site lies within the scuthwest Nevada volcanic field in the southern Great Basin and is a remnant of the Timber Mountain-Oasis Valley caldera complex. Thick deposits of ash-flow tuffs overlying Paleozolc carbonate deposits predominate at Yucca Mountain. Alluvium fills some of the washes on Yucca Mountain as well as adjacent basins such as Jackass Flats and crater Flat. The unsaturated zone is 'quite thick at Yucca Mountain (about 500 to $750 \mathrm{~m}$ ). The repository would be located $300 \mathrm{~m}$ or more below the land surface in the densely welded, devitrified tuff of the Topopah Spring Member. In addition to the lower portions of the Topopah Spring tuff, tuffs of the Calico Hills and the Prow Pass Member of the Crater Flat tuff are unsaturated below the repository location. Two additional units of the Crater flat tuff (the Bullfrog and Tram Members) arè in the saturated zone below Yucca Mountain. To the east of Yucca Mountain, all the tuff units mentioned above are partially or completely below the static water level. A summary of the mineralogy of Yucca Mountain has recently been published (Bish and Vaniman 1985). Farther from Yucca Mountain, the sequence of alluvium and tuff overlying Paleozoic carbonates persists in areas such as Jackass Flats, Yucca Flat, and Rainier Mesa; some exposure of Paleozolc carbonates also occurs. Static water levels in alluvium, tuff, or carbonates have been found (Claassen 1973).

At Yucca Mountain and vicinity, sodium is the primary cation and carbonate (as $\mathrm{H}_{2} \mathrm{CO}_{3}, \mathrm{HCO}_{3}{ }^{-}$, and $\mathrm{CO}_{3}{ }^{--}$) is the primary anion in water from the saturated zone (Benson et al. 1983; Ogard and Kerrisk 1984; Benson and Mckinley 1985). Other major cations present are calcium, potassium, and magnesium; other major anions are sulfate and chloride, with lesser quantities of fluoride and nitrate. Sodium and total carbonate concentrations are generally in the range of 2 to 10 mmoles/l. Aqueous silica is also present at a concentration of about 1 mmoles/1. Most waters have a $\mathrm{pH}$ in the 7 to 8 range and a temperature in the 25 to $40{ }^{\circ} \mathrm{C}$ range. In the wider area covering NTS, Oasis Valley, and the Amargosa Desert, the relative proportions of dissolved species is generally similar to water from Yucca Mountain; waters in the higher range of total concentrations of dissolved species are more often found, however, particularly in areas where evaporation is important. Examples also exist of different water compositions in specialized environments. 
Current USGS models indicate that, at Yucca Mountain, water would move generally downward (with some possibility of lateral transport) through the unsaturated zone and into groundwater in the saturated zone (Montazer and Hilson 1984). Thus, water chemistry in both the unsaturated and saturated zones is of interest. To date, numerous wells have sampled water from the saturated zone at Yucca Mountain, and other studies have examined water chemistry in nearby areas such as Oasis Valley, the Amargosa Desert, Pahute Mesa, and Rainier Mesa. Thus, information is avallable ahout saturated-zone water chemistry at Yucca Mountain and its relation to the chemistry of water in adjacent areas. However, no analyses of pore water from the unsaturated zone at Yucca Mountain have been reported. (Gas analyses from the unsaturated zone at Yucca Mountain have been published.) Some pore-water compositions from Rainier Mesa have been reported and can be used as a guide until data from Yucca Mountain are available. Because the distribution of available data is weighted heavily toward the saturated zone, this report will necessarily concentrate on chemistry of saturated-zone water. The importance of the chemistry of unsaturated-zone water at Yucca Mountain is recognized, however, and when sufficient data are avallable, a study emphasizing the unsaturated zone is planned.

The phrase "water chemistry" can have a variety of meanings. For this report, water chemistry relates to the identities and concentrations of dissolved spectes present in the water (including lsotoplc data where available), the origins of these species, and the chemical controls on their concentrations. An understanding of water chemistry at Yucca Mountain starts with compilations of local water compositions and mineralogy. However, Yucca Mountain cannot be viewed in isolation, so that similar data from surrounding areas are also useful. The similarity of water compositions and mineralogy in a larger area containing Yucca Mountain makes an area-wide comparison even more valuable. An understanding of the origins of dissolved species and chemical controls on their concentrations leads to knowledge of the chemical and physical processes that affect water compositions. This knowledge is important because Yucca Mountain is not a static system; future climatic changes and even the presence of a repository can change some of the parameters that control water composition, such as recharge rate, recharge mechanism, temperature, or materials that contact the water. Thus, in order to assess the effects of changes in boundary conditions, an understanding is 
necessary of the origins of dissolved species in the water and the processes that control their concentrations. For quantitative predictions, a quantitative model of water chemistry is required. At this time, however. only a qualitative understanding is available of most aspects of rucca Mountain water chemistry.

The following sections of this report (1) describe previous reports of water chemistry at Yucca Mountain and nearby areas, (2) discuss the wells at Yucca Mountain and vicinity that are the primairy focus of this report, (3) discuss some possible sources of groundwater at Yucca Mountain, (4) outline chemical and physical processes that can affect water compositions in this area, (5) present data for important compositiona? variables of water from the area and some relations among the compositional variables, (6) discuss controls that appear to exist on water chemistry at Yucca Mountain, and (7) discuss the implications of the water chemistry for solubility and speciation of waste elements and for mineral stability.

\section{PREVIOUS WORK}

Water from Yucca Mountain and many nearby areas has been sampled and analyzed. The operation of NTS led to test wells and producing wells in areas such as Yucca Flat, Frenchman Flat, Jackass Flats, and Pahute Mesa. In addition, springs and seeps have been sampled in some of these same areas as well as at Rainier Mesa. The compositions of water from areas near NTS have also been reported; these include Oasis Valley to the west of Yucca Mountain and NTS, and the Amargosa Desert to the south of NTS. In recent years, a number of test wells have been dug and sampled at Yucca Mountain as part of the NNWSI Project. Data from all of these locations provide a base for the analyses done in this report.

The sources of water-composition data that were reviewed and included in this investigation of groundwater chemistry are listed below along with a few words about the water sampled.

1. Clebsch and Barker. (1960), composition of water from wells and springs at Rainier Mesa,

2. Clebsch (196i), tritium analyses of water from NTS,

3. Blankennagel and Weir (1973), composition of water from wells at Pahute Mesa and vicinity, 
4. Claassen (1973), composition of water from various water-supply wells around NTS,

5. Benson (1976), composition of pore water from Rainter Mesa,

6. White (1979), composition of water from Oasis Valley,

7. White et al. (1980), composition of fracture water from Rainier Mesa,

8. Henne (1982), composition of fracture water from Rainier Mesa,

9. Benson et al. (1983), composition of water from wells in the vicinity of Yucca Mountain,

10. Ogard and Kerrisk (1984), composition of water from wells in the vicinity of Yucca Mountain,

11. Benson and Mckinley (1985), composition of water from wells in the vicinity of Yucca Mountain,

12. Claassen (1985), composition of water from wells and springs in the Amargosa Desert and at other locations at NTS and vicinity, and

13. White and Chuma (1986), composition of water from Oasis Valley and Pahute Mesa.

A tabulation of the various water compositions is given in Appendix A. In addition to the water-composition data outlined above, analyses of the gas phase from the unsaturated zone at Yucca Mountain have been reported by Yang et al. (1985). These data were taken from near-surface locations to about 368-m depth; they provide direct information about the gas phase contacting pore water in the unsaturated zone at Yucca Mountain, but only indirect information about the pore water.

A general review of groundwater chemistry in the south-central Great Basin was given by Winograd and Thordarson (1975). They Identified five types of groundwater in the area:

1. a calcium-magnesium-bicarbonate water that moves only through the carbonate aquifer or through a valley-f 111 aquifer that is rich in carbonate detritus,

2. a sodium-potassium-bicarbonate water that moves only through the tuff or lava-flow terrane, or through a valley-fill aquifer that is rich in volcanic detritus,

3. a mixture of the first two types that results from downward flow of the sodium-potassium-bicarbonate water into the carbonate aquifer,

4. a sodium-sulfate-bicarbonate water in east-central Death Valley, and 
5. a playa water that exists as shallow groundwater beneath saturated playas.

Winograd and Thordarson (1975) infer, on the basis of hydrochemical data, that groundwater beneath NTS moves toward the Ash Meadows area.

White (1979) reviewed the geochemistry of groundwater associated with tuffaceous rocks in Oasis Valley, which is west of NTS and Yucca Mountain. He concluded that most recharge entering Oasis Valley comes from the north and east, including Pahute Mesa. The water moves from the recharge areas through the fracture system in the tuffaceous rocks and into the alluvium in the valley floor. The close proximity of the water in the alluvium to the ground surface promotes evapotranspiration and an increase in concentration of the dissolved species. Some dissolved species such as sodium and chloride were not selectively ajded or removed from the water, but others such as calcium, fluorlde, aqueous silica, and bicarbonate were affected by precipitation or dissolution reactions.

White, Claassen, and Benson (1980) described the effect of volcanic glass dissolution on water chemistry in a tuffaceous aquifer at Rainier Mesa (see also Claassen and White 1979). Water containing dissolved carbon dioxide reacts with vitric and crystalline tuffs. As dissolution proceeds, the water becomes saturated with respect to various minerals. The competition between species added by dissolution and removed by precipitation controls water composition. Experiments with vitric and crystalitine tuff produced aqueous solutions of different composition, crystalline tuff giving more calcium-rich water and vitric tuff giving more sodium-rich water. The authors concluded that dissolution of vitric tuff was the predominant reaction affecting water composition; this predominance was probably related to different flow mechanisms in the two materials (fracture flow dominating in crystalline tuff and interstitial flow in vitric tuff). Cation compositions in fracture and pore water sampled at Rainier Mesa were similar, but pore water was higher in shloride and sulfate relative to blcarbonate than was fracture waters (see also Benson 1976). Kerrisk (1983) modeled glass dissolution and mineral precipitation reactions with reaction-path calculations. He was able to reproduce the general trends of major-species water composition and mineral precipitation by using glass dissolution data measured by white, claassen, and Benson (1980). 
Claassen (1985) reviewed data for groundwater in the west-central Amargosa Desert. He concluded that overland flow of snowmelt in or nea $i$ present-day stream channels was the primary recharge mechanism rather than subsurface flow from highland recharge areas in the north. Two of these stream channels are the Amargosa River, which enters the Amargosa Desert in the west from Oasis Valley, and Fortymile Wash (Fortymile Canyon), which passes Yucca Mountain on its way to the Amargosa Desert. Recharge through alluvium composed of fragments of tuff or carbonate, or mixtures of the two, and through playa deposits results in different water compositions. He also saw evidence for upward leakage of water from a regional ca:-bonate aquifer Into alluvium and mixing with water recharged directly into the alluvium at the eastern edge of the study area.

White and Chuma (1986) reviewed data for water from Oasis Valley and Fortymile wash. They used isotopic data to conclude that groundwater from Pahute Mesa discharges thrcugh tuffaceous aquifers into Oasis Valley, but not into Fortymile Wash. They also concluded that water in the alluvium in the upper north-central Amargosa Desert originated principally as groundwater in tuffs in Fortymile Wash; this disagrees with the conclusion of Claassen (1985) that overland flow was more important. White and Chuma (1986) infer that, during passage through Oasis Valley, dissolved carbonate in the water is exchanged with soli-zone carbon dioxide and carbonate in caliche; this exchange is facilitated by the proximity of the water to the ground surface in oasis Valley.

\section{YUCCA MOUNTAIN WELLS}

A number of wells have been completed and sampled at Yucca Mountain and vicinity as part of the NNWSI Project or other programs at NTS. Compositions of water from these wells have been reported primarily by Benson et al. (1983), Ogard and Kerrisk (1984), and Benson and McKinley (1985). Table I lists the 15 wells from Yucca Mountain and vicinity that were reviewed as part of this report. Wells J-12 and J-13 are water-supply wells; the others are test wells. Table I also lists the well locations and Fig. 1 shows the locations around Yucca Mountain.

All but one of the wells (UE-25p\#1) sample the tuffaceous aquifer around Yucca Mountain. Well UE-25p\#1 encountered the carbonate aquifer at about 1300-m depth and continued to about 1800-m depth (Craig and Robison 1984). 


\section{SOURCES OF GROUNDWATER}

One of the boundary conditions that influences the composition of saturated-zone water at Yucca Mountain is the source of the water. Water entering the area carries dissolved species with it. The identities and concentrations of these dissolved species depend on the past history of the water. There are three potential sources of groundwater in the tuffaceous aquifer at Yucca Mountain and vicinity: (1) subsurface flow from other recharge areas, (2) direct recharge from local precipitation or runoff, and (3) flow from the carbonate aquifer that underlies the tuffaceous aquifer. A hydrologic model of Yucca Mountain that outlines sources of groundwater in the saturated zone is still being developed by the USGS. However, some ideas about the likelihood of these sources can be obtained from the preliminary models that have been developed (Waddell et al. 1984; Robison 1984; Czarnecki 1985) and from consideration of nearby areas.

The general similarity of the composition of the tuffaceous-aquifer minerals around NTS and vicinity makes it difficuit to distinguish, from geochemical evidence alone, between subsurface flow through the tuffaceous aquifer from other recharge areas and direct recharge. Two different proposals for the source of groundwater in the southern part of Fortymile Wash have been made. Claassen (1985) concluded that groundwater was recharged primarily by overiand flow and local recharge, but White and Chuma (1986) considered subsurface flow more likely. In either case, the water would contact tuffaceous material in the aquifers or valley fill and have a similar overall composition.

The general flow direction from north to south proposed by Winograd and Thordarson (1975) for groundwater beneath NTS makes highland areas to the north of Yucca Mountain potential recharge areas. White (1979) and White and Chuma (1986) have concluded that groundwater from Pahute Mesa flows into Oasis Valley, but that it is not a source for groundwater in Fortymile Wash. The relationship between water from Pahute Mesa and Yucca Mountain is uncertain at this time.

Claassen (1985) found evidence for upward flow of water from the carbonate aquifer and mixing with water from the tuffaceous aquifer in local areas in the eastern Amargosa Desert. Springs in the Ash Meadows area also discharge water from the carbonate aquifer. No geochemical evidence of upward flow of carbonate aquifer water around Yucca Mountain has been reported; 
however, there are potentiometric data indicating this possibility (Robison 1984). Broxton et al. (1986) have proposed this process as the cause of a trend from more sodium- and potassium-rich zeolites in western Yucca Mountain to more calcium-rich zeolites in the eastern part.

\section{ACTIVE CHEMICAL AND PHYSICAL PROCESSES}

This section presents short discussions of chemical and physical processes that are active at Yucca Mountain and that could affect water comrositions. Its purpose is to remind the reader of those processes that could control water composition or that could change water composition as conditions change at Yucca Mountain.

\section{A. Transport with Water}

As discussed in Section IV above, transport of dissolved species with water that enters or leaves the Yucca Mountain area is an important process affecting water compositions. Because of the similarity of mineralogy in the tuffaceous aquifers at NTS, it may be that water entering Yucca Mountain by subsurface flow through the tuffaceous aquifer has already achleved a steady-state composition in the major cations and anions. Water from the carbonate aquifer has its own characteristic composition. Water directly recharged through the unsaturated zone may also have a different composition, but this has not been determined as yet.

\section{B. Rock-Water Reactions}

Dissolution of volcanic glass and minerals provides a major source of alkali metal and alkaline earth cations, and aqueous silica to water in the tuffaceous aquifer (Hoover 1968; Claassen and White 1979; White et al. 1980). Dissolution and secondary mineral precipitation are responsible for the sorptive minerals found at Yucca Mountain. Water-mineral reactions also stabilize the $\mathrm{pH}$ of the water (Ogard and Kerrisk 1984). These processes are particularly important for water that is recharged through the unsaturated zone. Reactions between water and carbonate minerals in the Paleozoic (carbonate) aquifer strongly influence the chemistry of that water.

c. Ion Exchange

Cation exchange between local water and secondary minerals such as clays and zeolites at Yucca Mountain can also change or control alkall metal and alkaline earth concentrations in the water. Isotopic exchange between 
dissolved carbonate species and carbonate minerals has also been reported (White and Chuma 1986).

D. Gas Dissolution

Various gases disso?ved in water influence water chemistry. At Yucca Mountain, two important gases are oxygen and carbon dioxide. Most saturated-zone water from Yucca Mountain and vicinity is oxidizing, contairing measurable quantities of dissolved oxyger: (Ogard and Kerrisk 1984). This affects the chemistry of many of the waste elements, particularly the actinides.

Water containing dissolved rarbonate species has an equilibrium carbon dioxide pressure that is a function of the amount of dissoived carbonate and the water composition, including pH. The atmosphere and the soil zone are two important sources of gaseous carbon dioxide. Precipitation and water passing through the soil zone pick up dissolved carbon dioxide. The carbon dioxide content of gas from the unsaturated zone and the isotopic composition of the gas has been measured at and near NTS (Henne 1982; White and Chuma 1986) and at Yucca Mountain ( $Y a n g$ et al. 1985). These data have not been related to the carbonate content of water from the saturated zone as yet.

E. Mixing of Different Water Compositions

There are two major aquifers in the vicinity of Yucca Mountain, the tuffaceous aquifer and the carbonate aquifer, which generally underlies the tuffaceous aquifer at NTS. The waters from these two aquifers have somewhat different compositions, and mixtures of the two extremes have been noted (Winograd and Thordarson 1975). This process could be important at Yucca Mountain if water from the carbonate aquifer enters the tuffaceous aquifer. F. Evaporation

Evaporation is observed in areas such as Oasis Valley where the static water level approaches the land surface. At Yucca Mountain, however, the deep unsaturated zone would preclude evaporation from saturated-zone water. There are two situations where evaporation may be important at Yucca Mountain: in the unsaturated zone and during the thermal pulse in the repository. In the matrix of the unsaturated zone, where liquid water presents a large surface area to the gas phase, evaporation may affect water compositions. Because of the limited amount of data about unsaturated-zone water compositions, little can be said about evaporation in the unsaturated zone at this time. 
VI. IMPORTANT GROUNDWATER COMPOSITIONAL VARIABLES AND RELATIONS AMONG THESE VARIABLES

The composition of groundwater represents direct evidence of the chemical and physical processes that are active in control of that composition. Water compositions and relations among compositional variables are of ten used to support interpretations or models about the origin or age of the water, or about its relation to the local area (Fritz and Fontes 1980; Drever 1982; Claassen 1985; White and Chuma 1986). This section presents information about relations among various compositional varlables of water from Yucca Mountain, NTS, and vicinity. The object of these presentations is to show relations where they exist and, in this and the following sections, to interpret these relations in terms of the physical and chemical processes that control water composition.

A. Major Species and Variables

Sodium is the primary cation in essentially all the saturated-zone water in this area. Calcium and potassium are next in importance, with calcium predominating in waters from the carbonate aquifer. Magnesium is also present in smaller quantities in these waters; it is more prominent in waters from the carbonate aquifer. The dissolution of volcanic glass and minerals in the tuffaceous and carbonate aquifers is the major source of these cations (Hoover 1968; Winograd and Thordarson 1975; Claassen and White 1979; White et al. 1980). Figure 2 shows plots of total sodium content as a function of total carbonate (the primary anion) content of water from Yucca Mountain, NTS, and vicinity. The meanings of the abbreviations shown in the legends are described in Table II. In Fig. 2(a), data from 187 samples are plotted; the data are segregated into 10 sets, primarily based on location. Definite clustering of some sets of data can be seen. Above about 6 minoles/l total carbonate, the data split into two groups; water from Oasis Valley continues to increase in sodium content with increasing carbonate, but other water does not. White (1979) concluded that the water in Oasis Valley is undergoing evaporation as it moves down the valley; this is demonstrated by the roughly linear variation of sodium and carbonate concentrations (as well as a number of other concentrations that will be discussed later) in that water. Three of the samples with high carbonate (9-10 mmoles/1) and intermediate sodium (5-7 mmoles/1) are from carbonate aquifer wells (UE-25p\#l carbonate water, Well $C$. and Well C-1). Some of the higher carbonate waters that fall in the group 

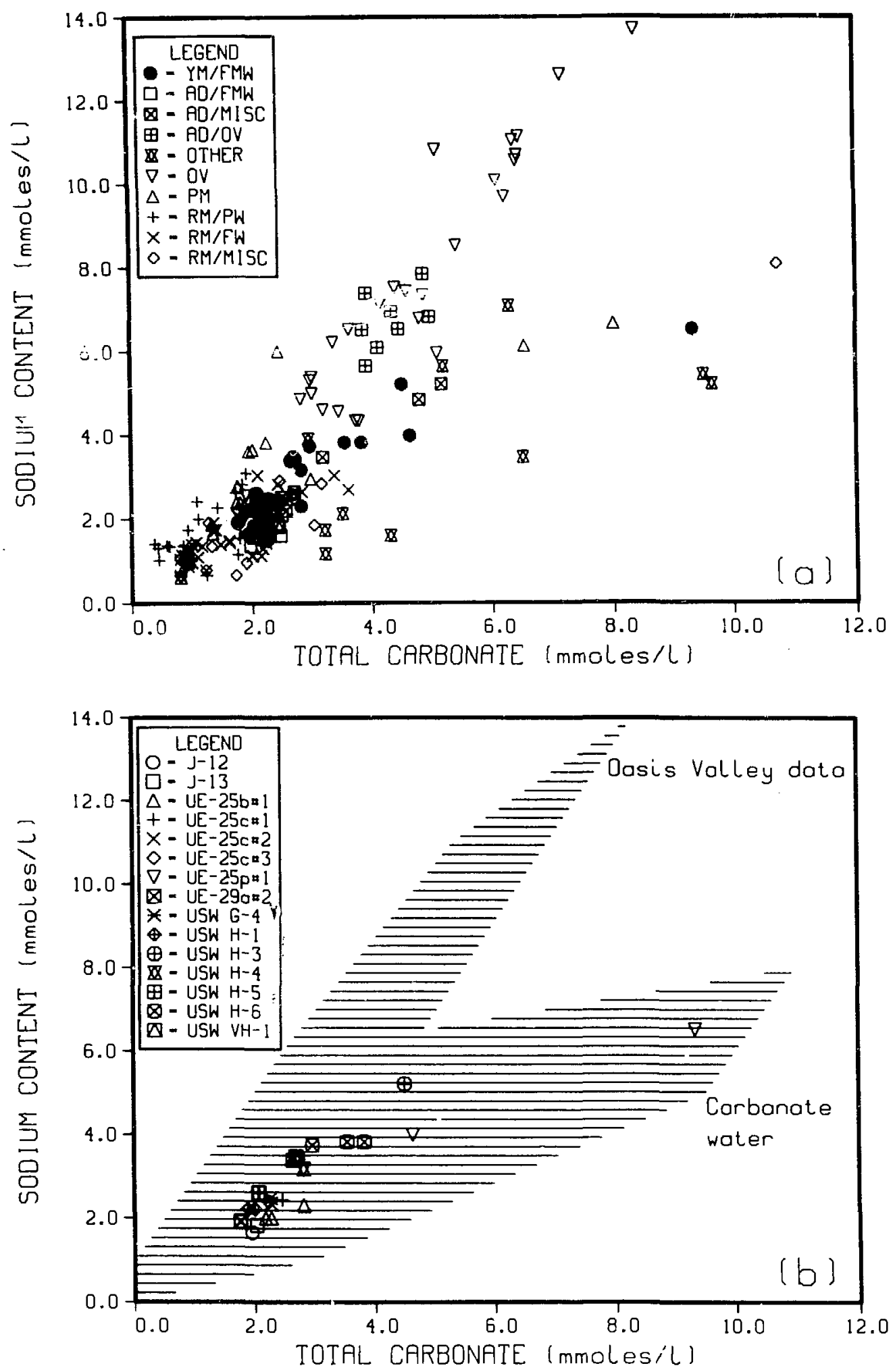

Fig. 2. Sodium content as a function of total carbonate content. a. All sampling locations (see Table II for meaning of legend abbreviations).

b. Yucca Mountain and vicinity. 
Abbreviation

YM/FMW

AD/FMN

AD/MISC

AD/OV

OTHER

OV

PM

$\mathrm{RM} / \mathrm{PW}$

RM/FW

RM/MISC

\section{Location}

Wells at Yucca Mountain and vicinity including Fortymile Wash ( $J-12, J-13, U E-25 b \# 1, U E-25 c \# 1, U E-25 c \# 2, U E-25 c \# 3$, UE-25p\#1, UE-29a\#2, USW G-4, USW $H-1$, USW H-3, USW $H-4$, USW H-5, USW $H-6$, and USW $\mathrm{VH}-1$ ).

Amargosa Desert wells and springs in the Fortymile Wash stream channel - sites 3 to 19 from Classen (1985).

Miscellaneous wells and springs in the Amargosa Desert - from Claassen (1985).

Amargosa Desert wells and springs in the Oasis Valley drainage system above the Fortymile Wash stream channel - sites 45 to 52 from Claassen (1985).

NTS wells and springs from Yucca Flat, Frenchman Flat, and the Calico Hills - Claassen (1973) and Claassen (1985).

Wells and Springs from Oasis Valley - White (1979) and White and Chuma (1986).

Wells from Pahute Mesa

Pore water from the unsaturated zone at Rainler Mesa - Benson (1976).

Fracture water from Rainier Mesa - White et al. (1980).

Miscellaneous wells, springs, and fracture-water samples from Rainier Mesa.

between the carbonate wells and the main body of the data may result from mixing more dilute water from the tuffaceous aquifer with water from the carbonate aquifer; two of these wells are from the tuffaceous aquifer at Pahute Mesa (UE-19C and UE-19d). Winograd and Thordarson (1975) identify a mixed tuffaceous-carbonate water in terms of downward flow of water from the tuffaceous aquifer into the carbonate aquifer. It is also possible that upward flow of water from the carbonate aquifer into the tuffaceous aquifer (Waddell et al. 1984) could result in a similar mixing process and similar water compositions. 
In Fig. $2(b)$, the shaded area represents the range of compositions covered in Fig. 2(a) by all the data, and only the compositions from Yucca Mountain and vicinity are plotted as specific points. Excluding data for the UE-25p\#1 carbonate water ( 9.3 mmoles/1 total carbonate), which is a carbonate aquifer sample, there is about a factor of 2 variation in the sodium and carbonate contents of water from the tuffaceous aquifer at Yucca Mountain. The trend of the compositions of the Yucca Mountain water with increasing carbonate content generally stays below the oasis valley data.

Figure 3 shows plots of total calcium content as a function of total carbonate content of water from Yucca Mountain, NTS, and vicinity. In Fig. $3(a)$, data from the same 187 sources that were shown in $F i g .2(a)$ are presented. As in Fig. 2(a), definite clustering of some sets of data can be seen in Fig. 3(a). The Oasis Valley data show a relatively constant calclum content with increasing carbonate, probably because of solubility constraints. In Fig. $3(b)$, the shaded area represents the range of compositions covered in Fig. $3(a)$ by all the data, and only the compositions from Yucca Mountain and vicinity are plotted as specific points. Except for both samples from UE-25p\#1, the water from Yucca Mountain has relatively low calcium content (less than 0.5 mmoles/1). This is particularly true of water from wells USW $\mathrm{H}-3, \mathrm{H}-6, \mathrm{H}-5$, and $\mathrm{H}-1$, which have calcium contents of 0.15 miroles/l or less. These wells are on the western part of Yucca Mountain or across Solitario Canyon. The Ghost Dance Fault is an approximate dividing line between these low calcium wells and those to the east with higher calcium content (see Section VI(D)).

Figure 4(a) shows a ternary plot of the relative sodium, calcium, and potasslum contents of water from Yucca Mountain, NTS, and vicinity. Water from the carbonate aquifer has high calctum (and magneslum), up to about $45 \%$ in the data shown in Fig. 4(a). Most of the Yucca Mountain waters plot along a line with about 0-5\% potassium, and sodium ranging from about $70 \%$ up to essentially 100\%; this is more apparent in Fig. 4(b), which shows a shaded area representing all the data in Fig. 4(a) with only Yucca Mountain data plotted as specific points. Two of the wells in Fortymile Wash ( $J-12$ and $\mathrm{J}-13$ ) have slightly higher relative potassium contents. An attempt was made to correlate the relative sodium content $(\mathrm{Na} /(\mathrm{Na}+\mathrm{Ca}+\mathrm{K}))$ of the water with other compositional variables, but no significant correlations were found for 

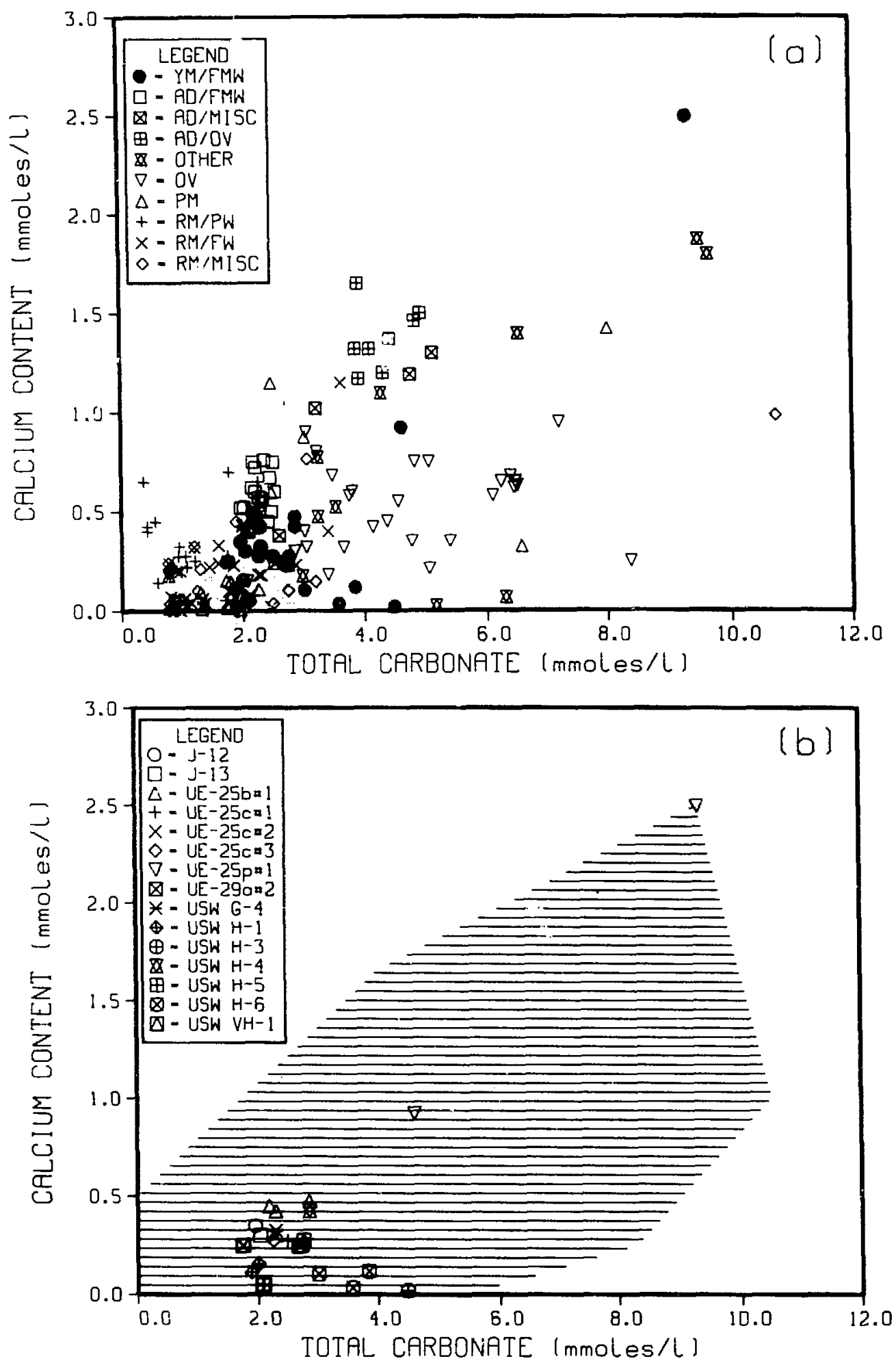

Fig. 3. Calcium content as a function of total carbonate content. a. All sampling locations (see Table II for meaning of legend abbreviations).

b. Yucca Mountain and vicinity. 


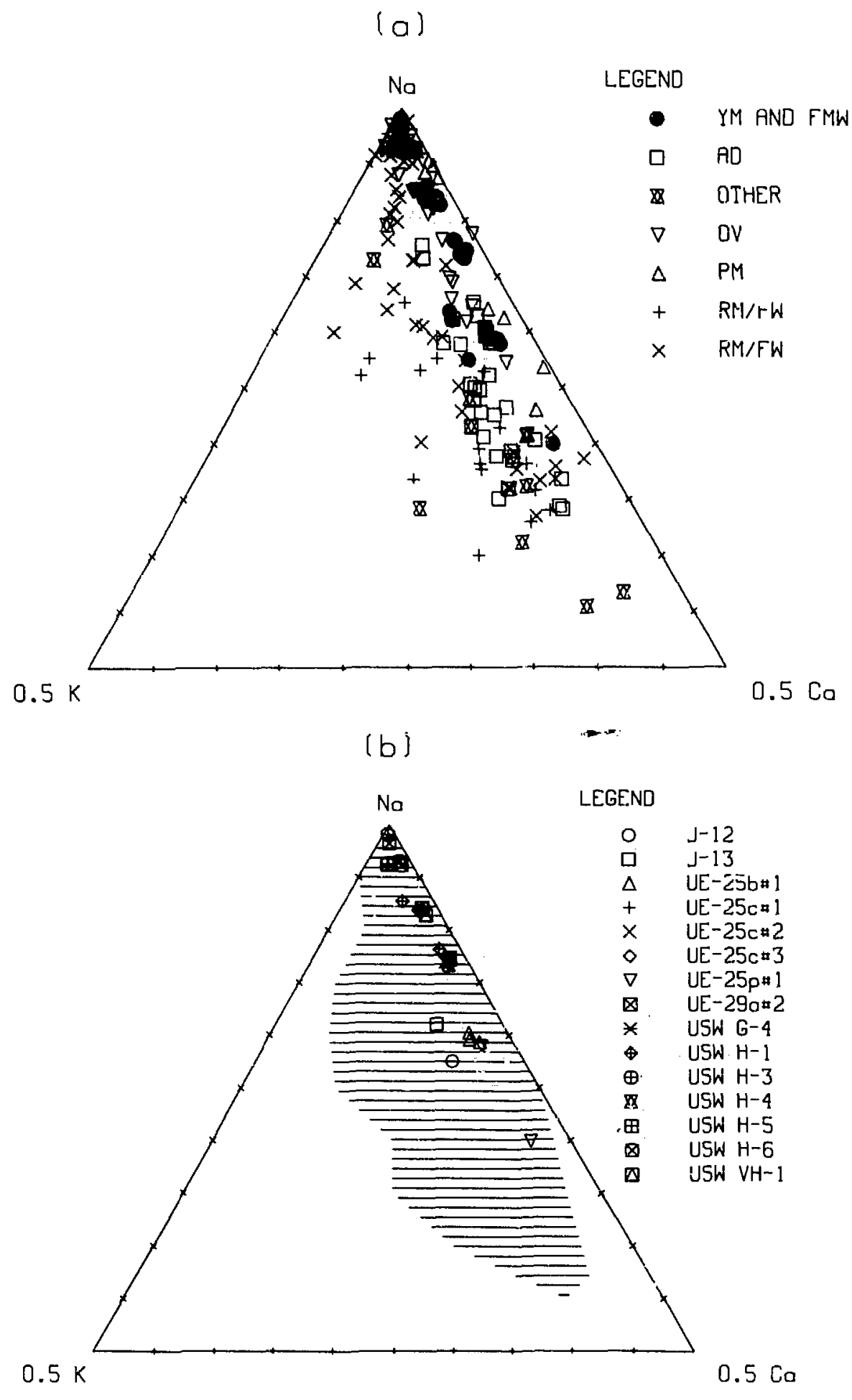

Fig. 4. Ternary diagram of relative sodium, calclum, and potassium content. a. All sampling locations (see Table II for meaning of legend abbreviations).

b. Yucca Mountain and vicinity. 
all the data. There is, however, a relation between relative sodium content and $\mathrm{pH}$ for water from Yucca Mountain and vicinity, and between relative sodium content and the location of Yucca Mountain we!is. Figure 5 shows a plot of $\mathrm{Na} /(\mathrm{Na}+\mathrm{C}-\mathrm{K})$ as a function of $\mathrm{pH}$ for water from Yucca Mountain and vicinity. In addition to the water data plotted there, the two lines show variation in the same variables from reaction-path calculations of volcanic-glass dissolution and secondary-mineral precipitation at Rainier Mesa (Kerrisk 1983). The general shape of the data, relatively flat at lower $\mathrm{Na} /(\mathrm{Na}+\mathrm{Ca}+\mathrm{K})$ values with increasing $\mathrm{pH}$ as $\mathrm{Na} /(\mathrm{Na}+\mathrm{Ca}+\mathrm{K})$ approaches 1 , is also predicted by the calculations. The variation of $\mathrm{Na} /(\mathrm{Na}+\mathrm{Ca}+\mathrm{K})$ with location is discussed in Section VI $(D)$.

The $\mathrm{pH}$ of water from Yucca Mountain, NTS, and vicinity is generally in the range of 7 to 9 . Two extreme values are observed at Yucca Mountain; the Cärbonate-water sample from UE-25p\#l has a pH of 6.6 and water from $\mathrm{H}-3$ has a $\mathrm{pH}$ of 9.2. The $\mathrm{pH}$ of all water samples as a group did not show any correlations with other compositional variables. However, at Yucca Mountain and vicinity, $\mathrm{pH}$ is related to a number of other compositional variables. The relation between $\mathrm{pH}$ and $\mathrm{Na} /(\mathrm{Na}+\mathrm{Ca}+\mathrm{K})$ was noted above and shown in $\mathrm{Fig}$. 5 . The $\mathrm{pH}$ is also inversely related to calcium content and, to some extent, to magnesium content. If the calcium content is related to $\mathrm{pH}$ through calcite solubility, a plot of $\log _{10}$ (calcium content) as a function of $\mathrm{pH}$ should be linear with slope -2 when the carbon dioxide partial pressure is constant, or curved with the slope varying from -2 through 0 with increasing $\mathrm{pH}$ when the total carbonate content is constant. Figure 6 shows a plot of $\log _{10}$ (calcium content) as a function of $\mathrm{pH}$ of water from Yucca Mountain and vicinity. Tlie slope of a curve through the data would decrease from about -2 at $\mathrm{pH} 6-7$ to about -1 at pH 8-9. This variation approximates the expected behavior for constant total carbonate content and would indicate that calcite solubility may be a factor in controlling the calcium content of water at Yucca Mountain. There is also a relation between $\mathrm{pH}$ and total carbonate content of tuffaceous-aquifer water from Yucca Mountain and vicinity (see Fig. 7). Although most of the tuffaceous-aquifer data are grouped together in one area, water with higher total carbonate content tends to have higher $\mathrm{pH}$. Water from UE-25p\#1 has high carbonate content but low $\mathrm{pH}$; thus, it does not fit this trend. 


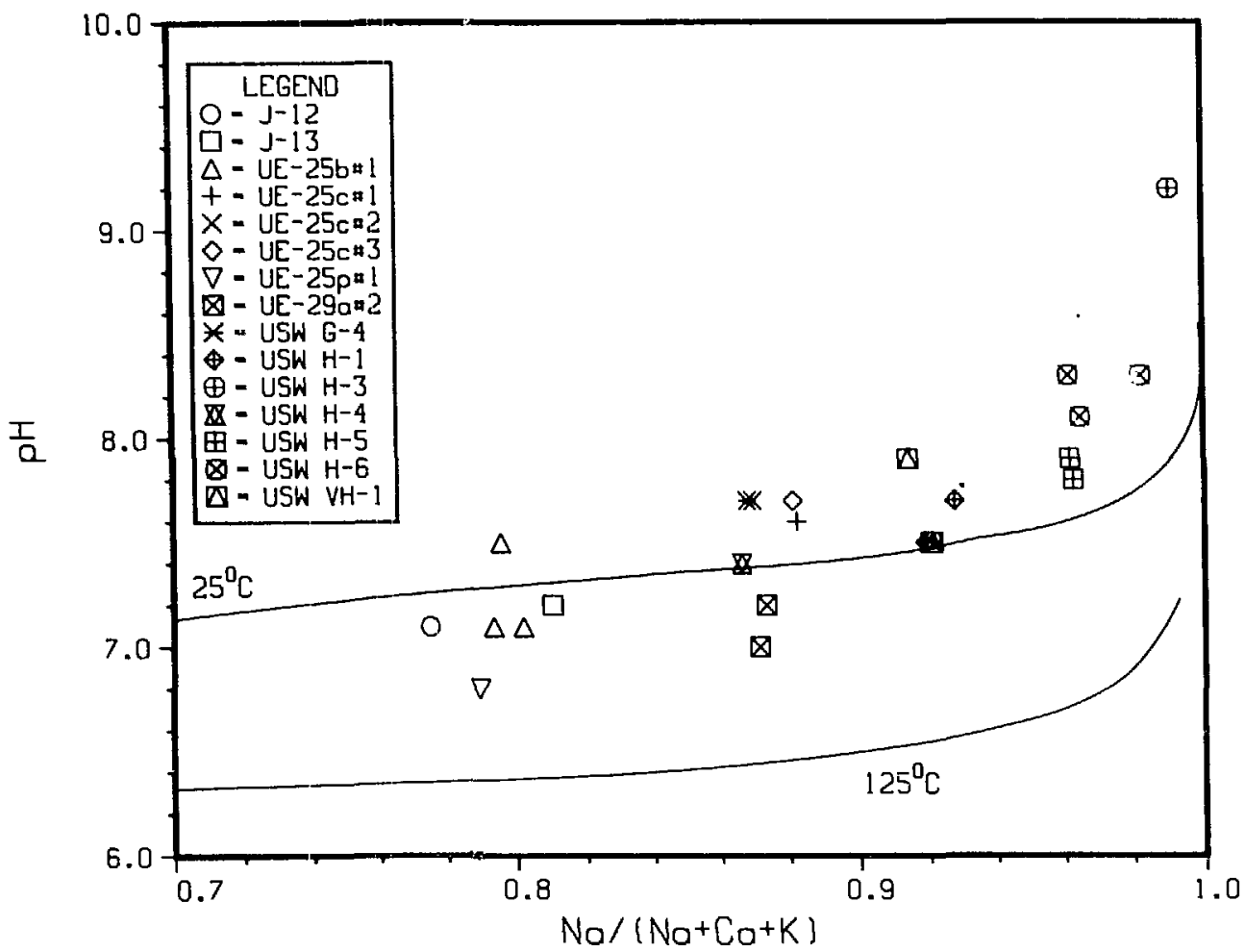

Fig. 5. $\mathrm{Na} /(\mathrm{Na}+\mathrm{Ca}+\mathrm{K})$ as a function of $\mathrm{pH}$ at Yucca Mountain and vicinity. Solid lines represent calculated results from Kerrisk (1983).

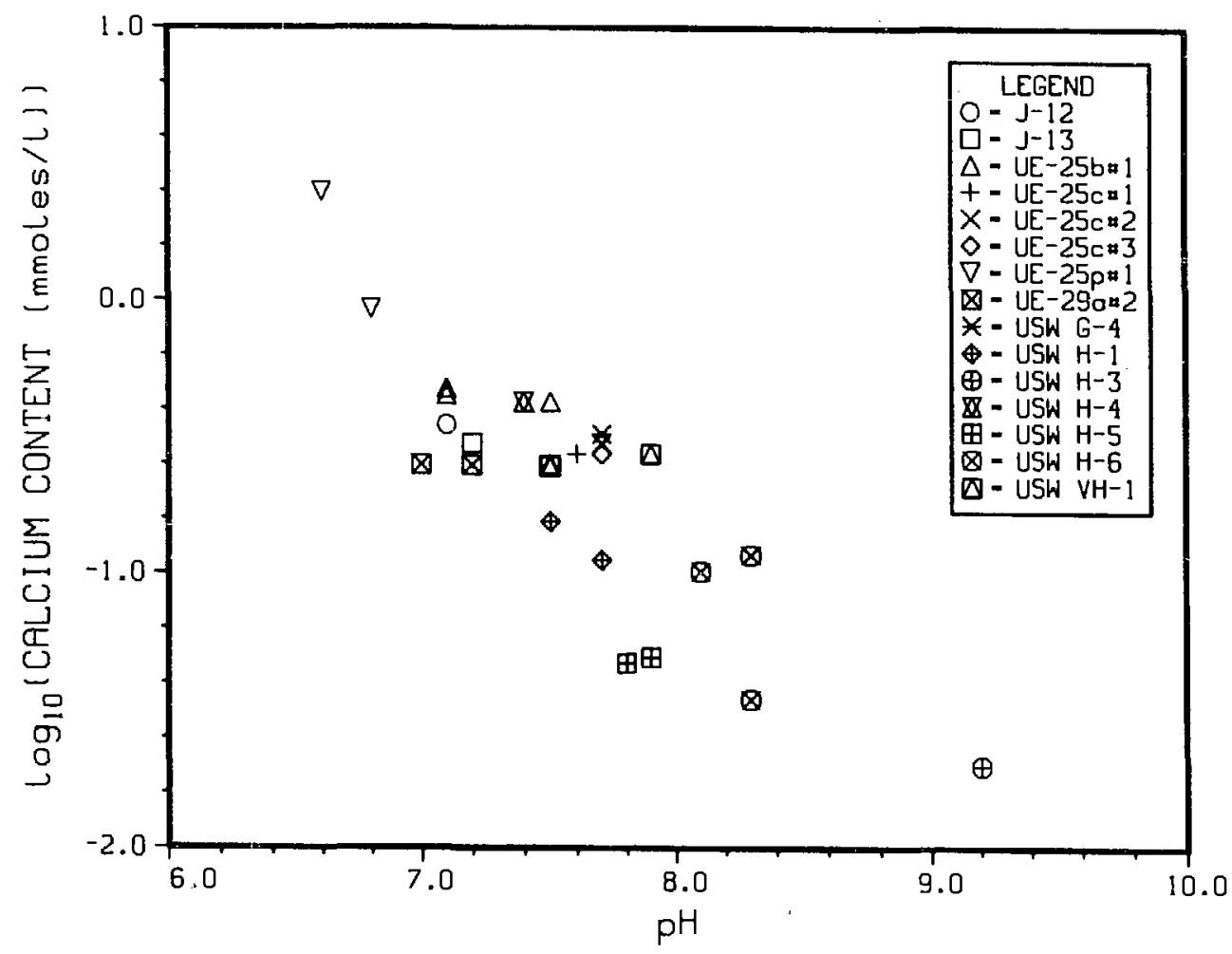

Fig. 6. The $\log _{10}$ (calcium content) as a function of $\mathrm{pH}$ at Yucca Mountain and vicinity. 


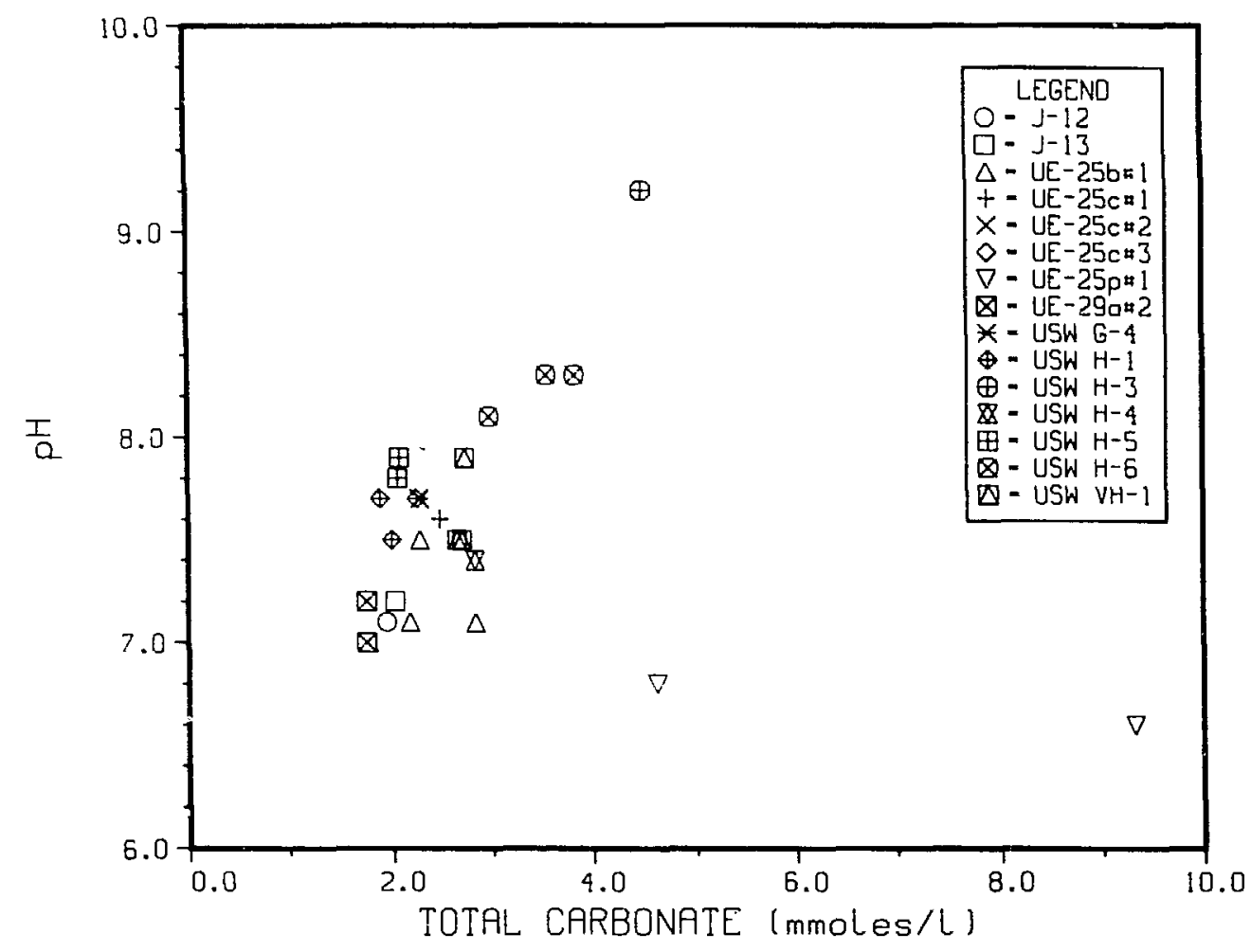

Fig. 7. The $\mathrm{pH}$ as a function of total carbonate content at Yucca Mountain and vicinity.

The carbon dioxide partial pressure in equilibrium with water compositions was calculated using the EQ3 chemical equilibrium computer program (Wolery 1983) for about two-thirds of the samples reviewed here.

Figure $8(a)$ shows a plot of $\log _{10}$ (carbon dioxide pressure) as a function of $\mathrm{pH}$ for samples from Yucca Mountain, NTS, and vicinity. There is a trend toward decreasing carbon dioxide pressure with increasing $\mathrm{pH}$. As expected, water from the carbonate aquifer tends to have higher equilibrium carbon dioxide pressures than water from the tuffaceous aquifer. The Rainier Mesa pore water shown in Fig. $8(a)$ has lower equilibrium carbon dioxide pressures than the fracture water. Figure $8(b)$ shows a similar plot for data just from Yucca Mountain and vicinity. There is much less scatter in these data. The slope of a line through the UE-25p\#l data is about -2 ; in the higher $\mathrm{pH}$ range (7.5 to 9 ), the slope is about -1 . The maximum carbon dioxide pressure calculated for tuffaceous waters from Yucca Mountain $\left(\sim 10^{-2} \mathrm{~atm}\right)$ is similar to peak carbon dioxide pressures observed in the soil zone at Yucca Mountain (Yang et al. 1985). Thus, soil-zone carbon dioxide is a possible source of the aqueous 

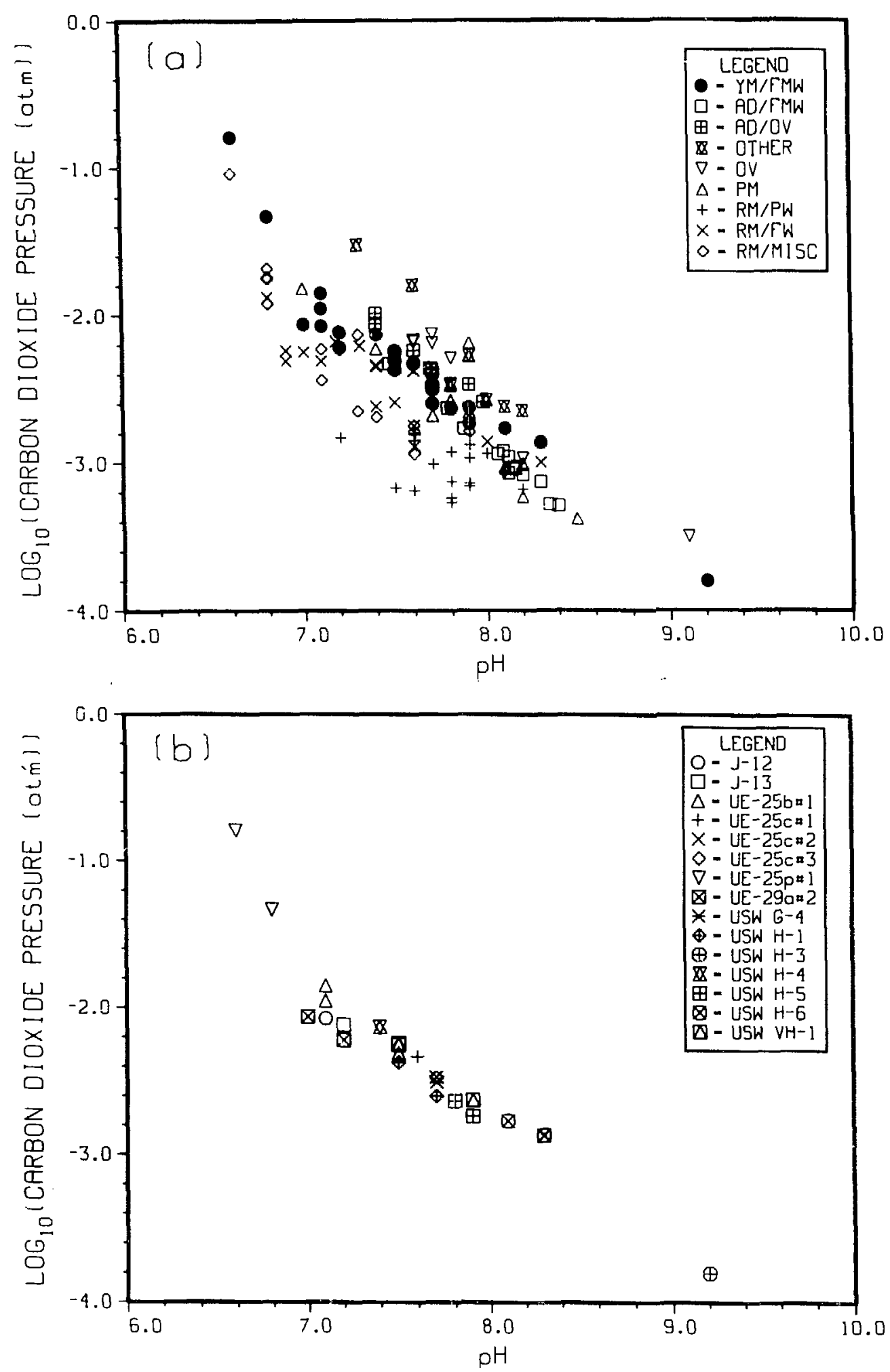

Fig. 8. The $\log _{10}$ (carbon dioxide pressure) as a function of $\mathrm{pH}$.

a. All sampling locations (see Table II for meaning of legend abbreviations).

b. Yucca Mountain and vicinity. 
carbonate in the water The calculated carbon dioxide pressure of water from Well $\mathrm{H}-3$ at Yucca Mountain $\left(10^{-3.8} \mathrm{~atm}\right)$ is below the carbon dioxide pressure in the atmosphere $\left(10^{-3.5} \mathrm{~atm}\right)$ and well below carbon dioxide pressures measured in the gas phase if the unsaturated zone at Yucca Mountain (Yang et al. 1985). This water also has the highest total earbonate content of the tuffaceous aquifer wells at Yucca Mountain. The high carbonate content of this water could result from some process that increases the $\mathrm{pH}$, thus driving down the equllibrium carbon dioxide pressure of the water to the level where it is below carbon dioxide partial pressures in the unsaturated-zone gas phase above the water, and allowing dissolution of gas-phase carbon dioxide in the water.

As could be implied from the relations between $\mathrm{pH}$ and total carbonate (Fig. 7), and carbon dioxide pressure and $\mathrm{pH}$ (Fig. $8(\mathrm{~b})$ ) for tuffaceous water at Yucca Mountain, there is also a relation between carbon dioxide pressure and total carbonate for these data (see Fig. 9). For the tuffaceous wells, those with higher total carbonate tend to have lower carbon dioxide pressures. This is consistent with the possiblilty that gas-phase carbon dioxide in the unsaturated zone could be the source of aqueous carbonate contents above about 2 mmoles/1 in tuffaceous-aquifer water from Yucca Mountain. The two samples from UE-25p\#1, which represent carbonate aquifer water and mixed tuffaceous-carbonate water, do not fit this trend (see figs. 7 and 9).

The discussions about relations among pH, total carbonate, calcium content, and equilibrium carbon dioxide pressure in the previous two paragraphs alluded to the possibility that calcite or dolomite solubilities may also be involved in controlling water chemistry at Yucra Mountain. The state of water with respect to saturation with a mineral can be represented $t: y$ the quantity $\log _{10}(Q / K)$, where $Q$ is the ion activity product and $K$ is the equilibrium constant for the solubility reaction (Stumm and Morgan 1981). The quantity $\log _{10}(Q / K)$ is negative for undersaturation, zero at saturation, and positive for oversaturation. Figure 10 shows a plot of calcite $\log _{10}(Q / K)$ as a function of $\mathrm{pH}$ for water from Yucca Mountain and vicinity. The $\log _{10}(\mathrm{Q} / \mathrm{K})$ data were calculated from water compositions using the EQ3 chemical equilibrium computer program at the same time that carbon dioxide pressures were calculated (Wolery 1983). Most of the waters with high pH are near saturation with respect to calcite; these are the same waters that showed low 


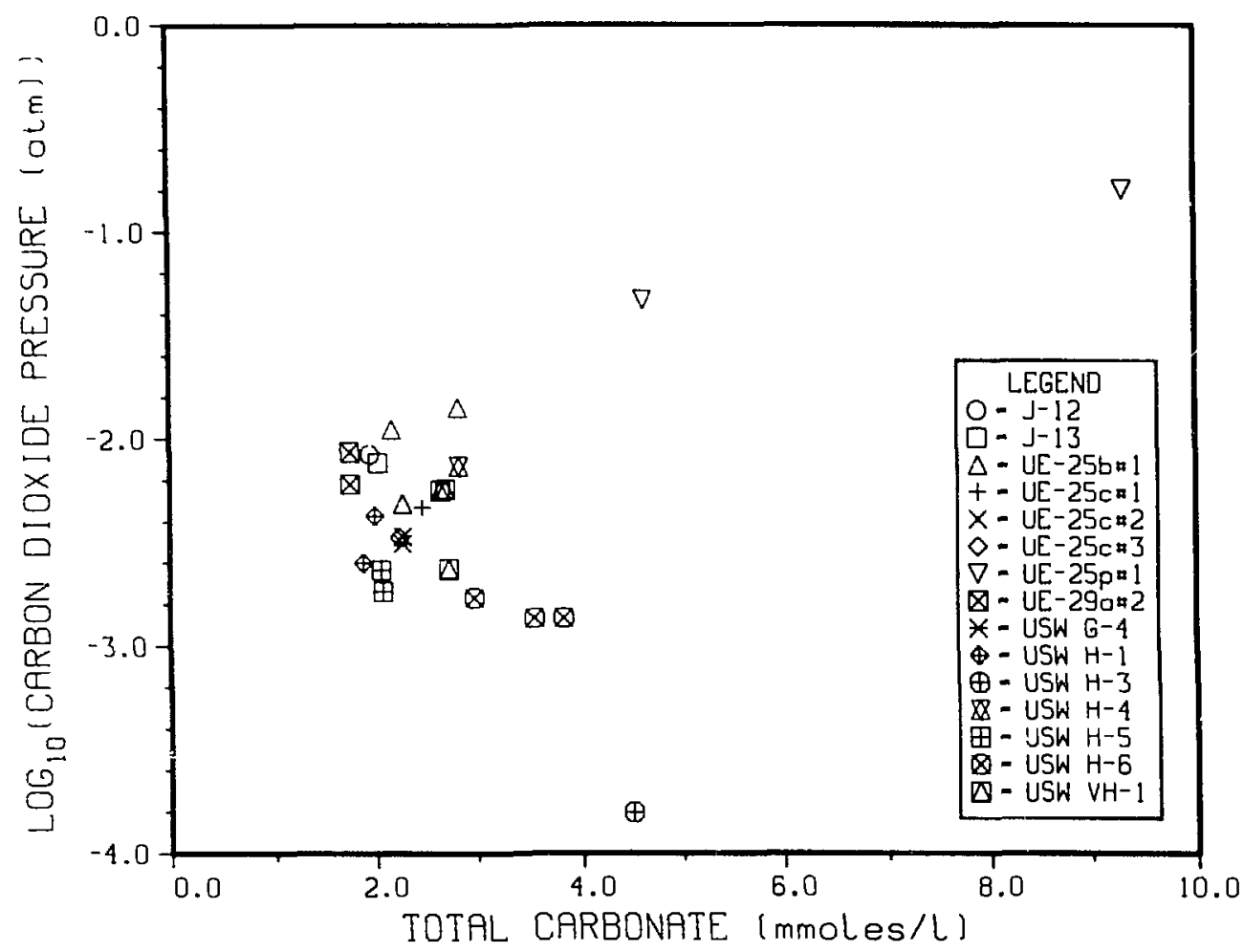

Fig. 9. The $\log _{10}$ (carbon dioxide pressure) as a function of the carbonate content at Yucca Mountain and vicinity.

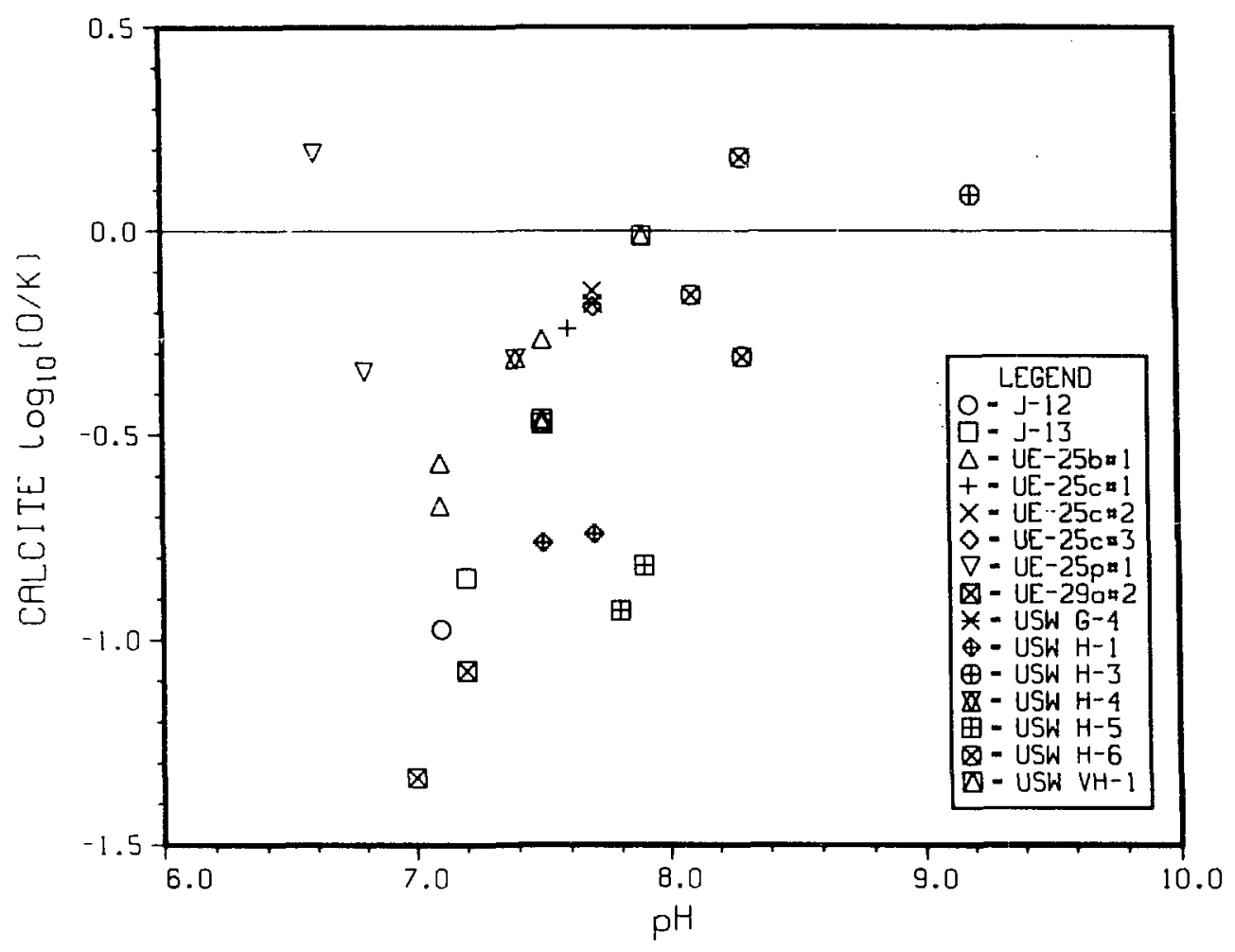

Fig. 10. Calcite $\log _{10}(Q / K)$ as a function of $\mathrm{pH}$ at Yucca Mountain and vicinity. 
calcium contents in Fig. 6. Thus, the low calcium content of these waters may be the result of calcite (or dolomite) precipitation as water pH increases. The low calciuln content and the high carbonate content in the tuffaceous-aquifer water in the western part of Yucca Mountain may be connected phenomena.

Essentially all the aqueous silica contents of the waters from Yucca Mountain, NTS, and vicinity range from about 0.6 to $1.3 \mathrm{mmoles} / 1$, with an average of $0.89 \mathrm{mmoles} / 1$. This puts the water in the range of cristobalite to amorphous silica saturation. A few samples show higher and lower values. In particular, water sampled from the surface soll of Rainier Mesa show lower aqueous silica contents, 0.3 to 0.6 mmoles/l (Benson 1976; Henne 1982). Wells that tap the carbonate aquifer (Wells Army-1, C, and $C-1$ ) are also low in aqueous sllica; Winograd and Thordarson (1975) noted the low aqueous silica content of water from the carbonate aquifer. The aqueous silica contents of waters from this area did not show significant correlations with any of the other compositional variables examined. Aqueous silica is supplied to these waters primarily by dissolution of tuffaceous rock and minerals; concentrations are probably controlled by precipitation of various solid silica polymorphs. Kerrisk (1983) has proposed that high aqueous silica activity (in equilibrium with cristobalite) is required for the presence of the zeolites found at Yucca Mountain.

Carbonate is the primary anion in essentially all the water from Yucca Mountain, NTS, and vicinity. After carbonate, chloride and sulfate are next in order of amount present; these two antons are generally present in about equimolar quantities. Carbonate, chloride, and sulfate usually represent $95 \%$ or more of the anion content of the water. Figure 11 shows plots of (chloride + sulfate) content as a function of total carbonate content of these waters. In Fig. $11(a)$, data from 185 sources are plotted. Three types of behavior can be seen moving away from the dilute region of the plot. Many samples of Rainier Mesa pore water show high (chloride + sulfate) content (1-2.5 mmioles/1) for the amount of carbonate present (0.4-1 mmoles/1) (the data cluster near the vertical axis); this is consistent with the low equilibrium carbon dioxide pressures calculated for this water (see Fig. $8(a)$ ). Data from Oasis Valley show a roughly linear trend of increasing (chloride + sulfate) 

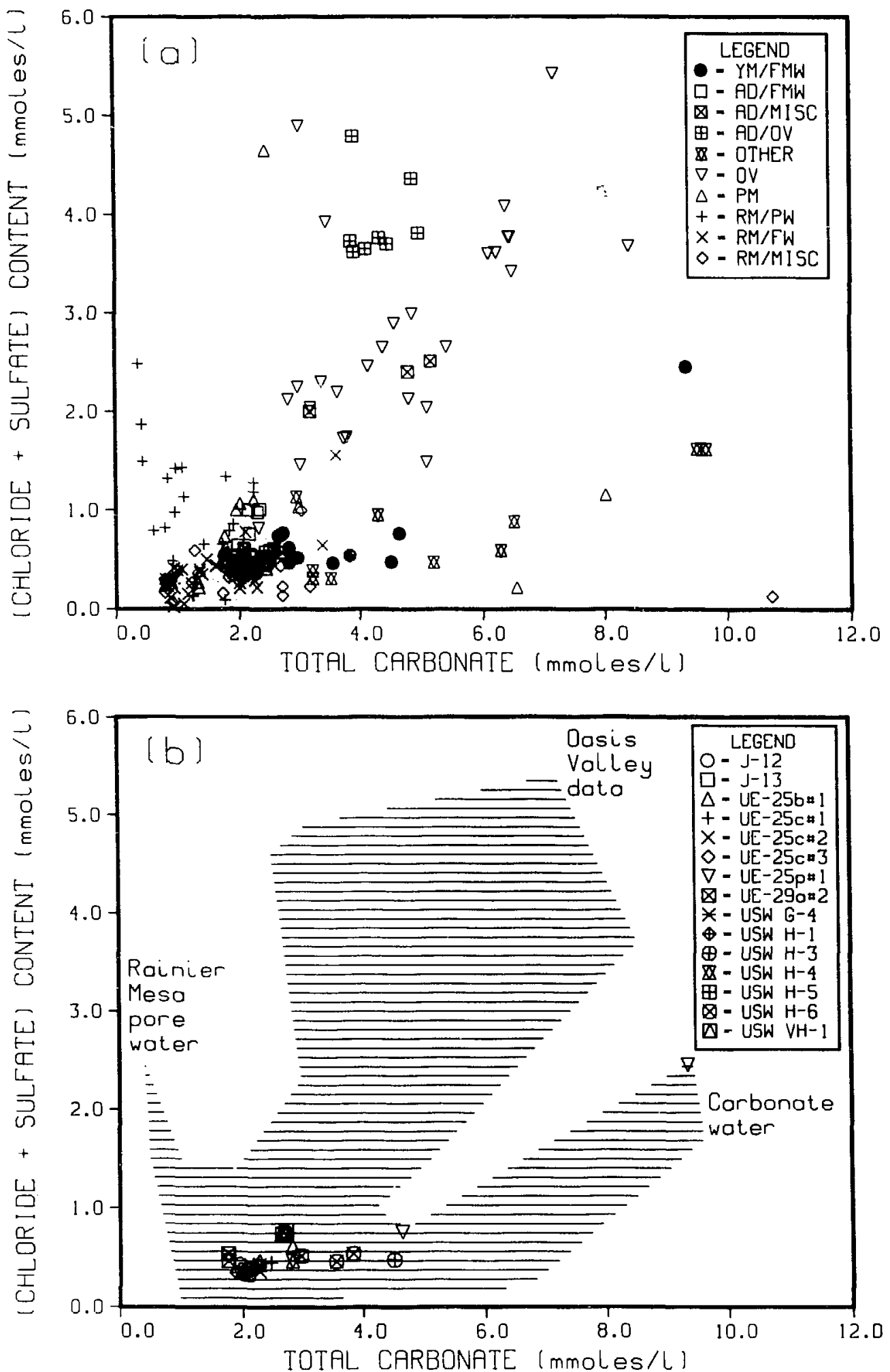

Fig. 11. The (chloride + sulfate) content as a function of total carbonate content.
a. All sampling locations (see Table II for meaning of legend abbreviations).
b. Yucca Mountain and vicinity. 
with carbonate; water from the Amargosa Desert in the Oasis Valley drainage system has somewhat higher (chloride + sulfate) content. These data tend to cluster in the middle of the plot. Water from carbonate aquifer wells and other wells around NTS shows lower (chloride + sulfate) content for the amount of carbonate present; these data cluster near the horizontal axis. In Fig. $11(b)$, the shaded area represents the range of compositions covered in Fig. li(a) by all the data, and only compositions from Yucca Mountain and vicinity are plotted as specific points. Except for UE-25p\#l carbonate water, water from Yucca Mountain and vicinity is low in (chloride + sulfate), 0.3-0.8 mmoles $/ 1$. Figure $12(a)$ shows an expanded-scale plot of sulfate content alone as a function of carbonate content for water from Yucca Mountain and vicinity; Fig. 12(b) shows a similar plot for chloride. Neither plot includes the carbonate water from UE-25p\#1 (sulfate content 1.67 mmoles/1, chloride content 0.79 mmoles $/ 1$, and carbonate content 9.3 mmoles/1), but they both include the mixed tuffaceous-carbonate water from this well. The sulfate content shows an almost linear relation with carbonate except for Well VH-1 (see Fig. 12(a)). There is enough scatter in the chloride plot so that there appears to be little or no relationship between chloride and carbonate for these wells (see Fig. 12(b)).

Figure 13 shows plots of sulfate content as a function of chloride content for water from Yucca Mountain, NTS, and vicinity. In Fig. 13(a), data from 185 sources are plotted. Most of the data cluster around the origin, with less than 0.5 mmoles/l sulfate and chloride contents. The straight line through the origin, with a slope of 0.82 , represents a least squares fit of all the data. Claassen (1985) shows a similar plot with a line representing evaporation of modern precipitation; the slope of that line is approximately 1.65. that is, twice the slope of the line in Fig. 13(a). Claassen (1985) also noted that groundwater in the Amargosa Desert contains less sulfate relative to chloride than modern precipitation. EQ3 calculations of gypsum $\log _{10}(Q / K)$ for about two-thirds of the samples in Figs. 12 and 13 gave values from -5 up to about -1 . This indicates that all these waters are undersaturated with respect to gypsum so that gypsum solubility should not limit sulfate concentrations. The Rainier Mesa pore-water data with high (chloride + sulfate) in Fig. 11(a) plot below the line in Fig. 13(a), with sulfate content about half the chloride content. Figure 13(b) shows an 

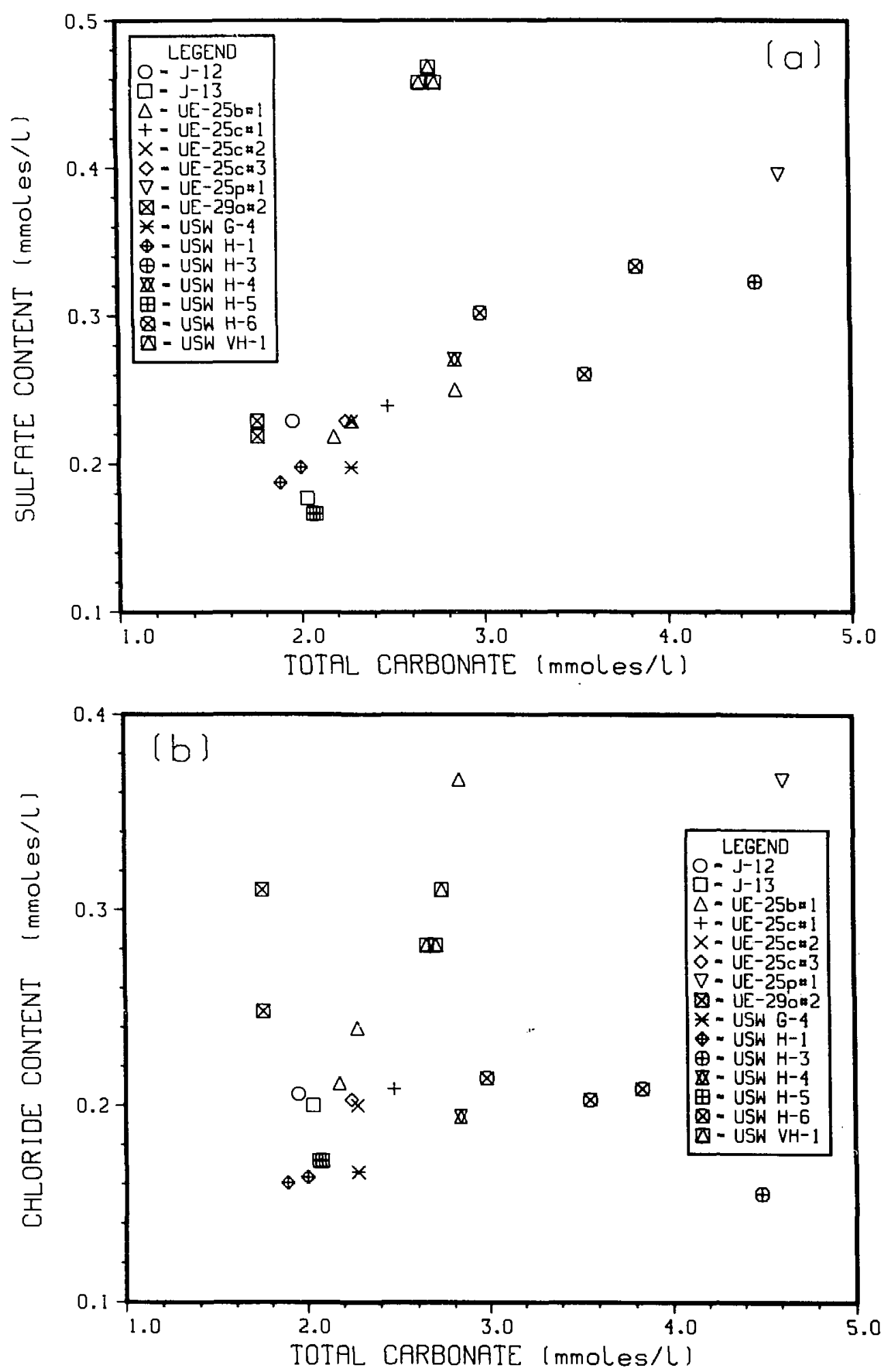

Fig. 12. Sulfate and chloride contents as a function of total carbonate content at Yucca Mountain and vicinity. a. Sulfate content as a function of total carbonate. b. Chloride content as a function of total carbonate. 

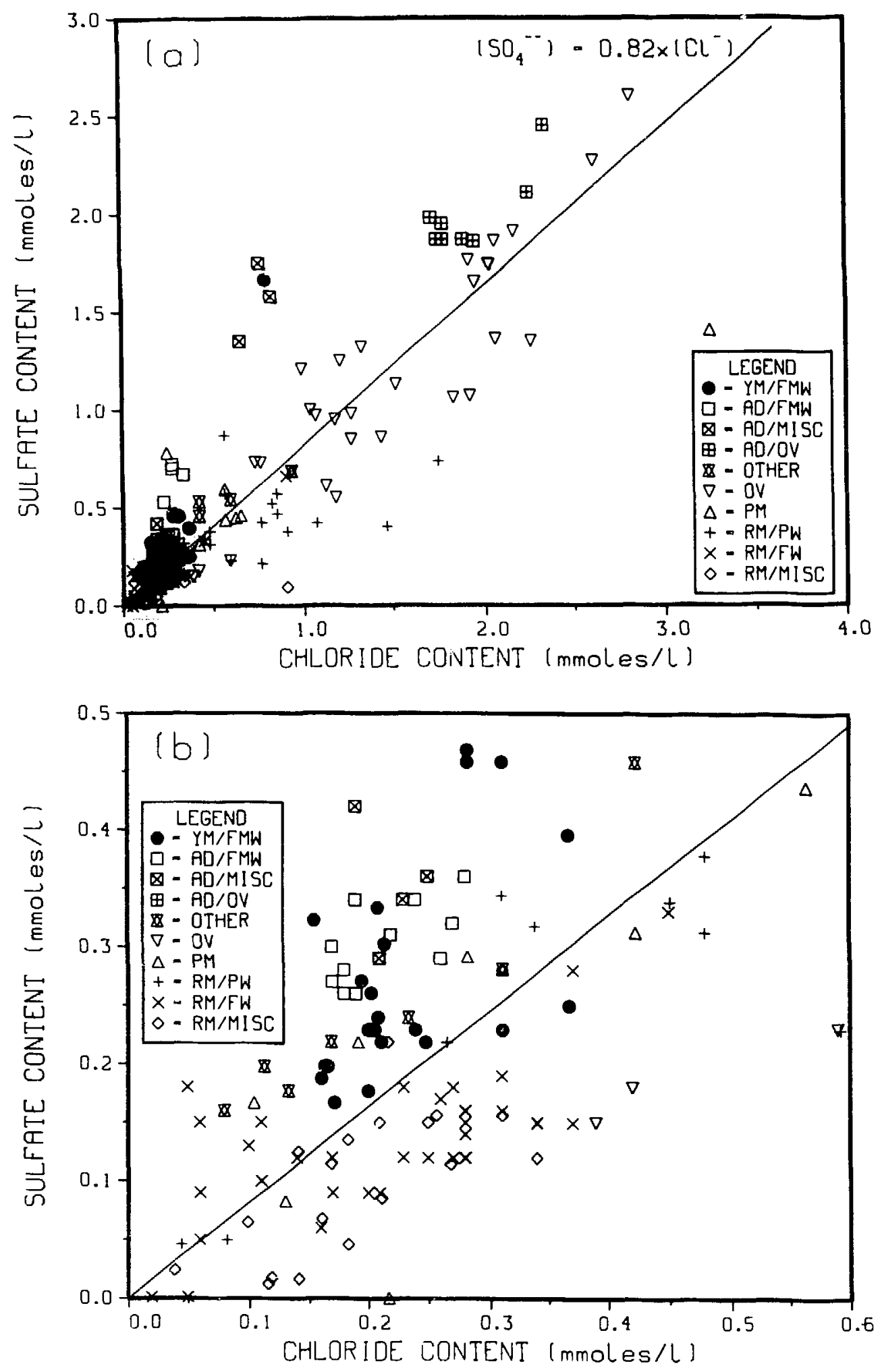

Fig. 13. Sulfate content as a function of chloride content (see Table II for meaning of legend abbreviations). a. All sampling locations.

b. Expanded plot of region near the origin. 
expanded view of the region near the origin; most of the data from Yucca Mountain wells appear in this region. The straight line is the same line shown in Fig. 13(a).

Measurements of the redox state of water have been made for some wells at Yucca Mountain and vicinity but have not been réported for any of the other waters reviewed here. Dissolved oxygen, Eh, and nitrite/nitrate ratios have been measured (Ogard and Kerrisk 1984). Most of the waters measured showed detectable dissolved oxygen ( 2 to $6 \mathrm{mg} / \mathrm{l}$ ) and Eh values in the 200- to 400-mV range (against a $\mathrm{H}_{2}$ electrode). Both measures are signs of oxidizing conditions. Two wells, UE-25b\#l and USW H-3, had dissolved oxygen contents below detection limits $(0.1 \mathrm{mg} / 1)$ and negative values of Eh in pumped samples. During a 28-day pumping test from a packed-off interval of the Bullfrog Member tuff in Well UE-25b\#1, reducing conditions at the start of the test gave way to oxidizing conditions at the end; the measured Eh of the water increased, dissolved oxygen increased during the latter third of the test, and the total iron, total manganese, and nitrite/nitrate ratio decreased (Daniels et a1. 1983; Ogard et at. 1983; Rundberg et al. 1985). All these trends are indications that the water became more oxidizing as the test progressed. However, the three direct measures of the redox state, dissolved oxygen, Eh, and nitrite/nitrate ratio, gave conflicting quantitative information. The lack of equilibrium among various redox couples that can exist in solution is common (Lindberg and Runnells 1984). The other well to show reducing conditions during pumping tests, USW H-3, had detectable dissolved oxygen that decreased with time early in a three-month pumping test; however, the water stabilized at oxygen levels below detection and Eh in the range of -80 to -140 $\mathrm{mV}$ for most of the test (Crowe and Vaniman 1985). The oxidizing conditions observed early in the USW $\mathrm{H}-3$ test were probably a result of contamination during drilling. Two other wells, USW $\mathrm{H}-1$ and $\mathrm{H}-4$, showed reducing conditions (negative values of Eh and detectable sulfide concentrations) in samples taken in evacuated bottles that were lowered into the well bores to various depths after pumping tests were completed and the pumps removed (Ogard and Kerrisk 1984). Well USW H-4 water had positive Eh and considerable dissolved oxygen in the sample taken during pumping. In addition to the redox measurements on water samples, measuremenis of the composition of the unsaturated-zone gas phase at Yus:a Mountain have shown about 20\% oxygen present even at 300-m 
depth (Yang 1986). The presence of gaseous oxygen above the static water level is an indication that water at that level should be oxidizing. The existence of a wide range of redox conditions in water from Yucca Mountain and vicinity, and the variation of redox conditions in individual wells, have not been satisfactorily explained at this time.

B. Isotopic Data

There have been a number of measurements of carbon, hydrogen, and oxygen isotopic data on the waters reviewed here. These data of ten provide information about the origin of the water or the physical and chemical processes that the water has undergone (Fritz and Fontes 1980; Faure 1977; Dansgaard 1964; Craig 1961). Figure 14 shows plots of the percentage of modern carbon (PMC) in aqueous carbonate as a function of total carbonate content of water from Yucca Mountain, NTS, and vicinity. PMC is a measure of the ${ }^{14} \mathrm{C}$ content of carbon in terms of the ${ }^{14} \mathrm{C}$ content of a carbon standard, and it ranges from about $100 \%$ for carbon that is in equilibrium with the atmosphere to $0 \%$ for carbon that has been isolated from sources of ${ }^{14} \mathrm{C}$ for a long time (Fritz and Fontes 1980). Values of PMC greater than $100 \%$ are also found because the standard represents ${ }^{14} \mathrm{C}$ contents before atmospheric nuclear testing increased the ${ }^{14} \mathrm{C}$ content of the atmosphere. Carbonate derived from Paleozolic rocks has very low values of PMC. The apparent age $\left(t_{a}\right)$ of the water is related to PMC by

$$
t_{a}=-[\ln (P M C / 100)] / \lambda \text {, }
$$

where $\lambda=1.24 \times 10^{-4} / \mathrm{yr}$ is the decay constant of ${ }^{14} \mathrm{C}$. In Fig. 14(a), data for 53 samples are plotted. There are two distinct trends apparent. The data from Oasis Valley show an increase in PMC with increasing carbonate content, and were explained by white and Chuma (1986) in terms of contact between the water in the shallow saturated zone of Oasis valley and soil-zone carbon dioxide or caliche; this leads to increasing PMC as the water moves down the valley. Some of the increase is caused by an addition of carbonate to the water and some by isotopic exchange between aqueous carbonate and the soil-zone sources. The data from Yucca Mountain and vicinity, on the other hand, show a range of PMC (20\% to $60 \%$ or apparent ages of 13000 to $4000 \mathrm{yr}$ ) at 2 mmoles $/ 1$ total carbonate with a trend toward decreasing PMC with increasing carbonate content above 2 mmoles/1; this trend is more apparent in Fig. 14(b), 

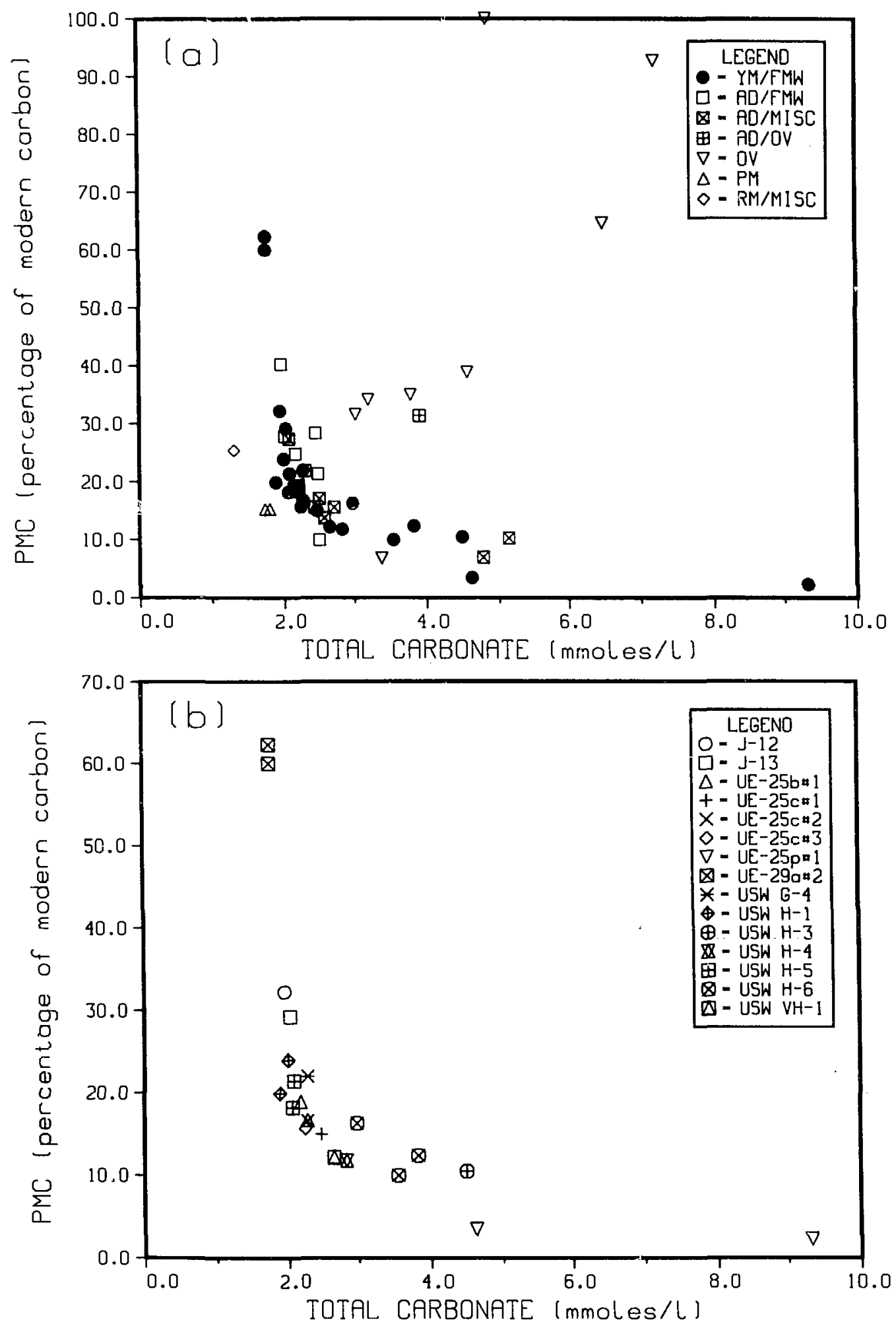

Fig. 14. Percentage of modern carbon as a function of total carbonate content.

a. All sampling locations (see Table II for meaning of legend abbreviations).

b. Yucca Mountain and vicinity. 
where only the Yucca Mountain data are plotted. It is not clear whether there is a connection between the tuffaceous water data and UE-25p\#l data, or whether the tuffaceous water data level off at about 10\% PMC (apparent age $18500 \mathrm{yr}$ ). A connection could indicate that the trend in Fig. 14(b) is caused by the addition of carbonate water to the tuffaceous aquifer (see Section $\operatorname{VII}(B))$.

Another feature of the data in Fig. 14(b) is that those wells with the highest values of PMC or youngest apparent age (UE-29a\#2, J-12, and J-13) are in Fortymile Wash where local recharge may be high (Claassen 1985). These two characteristics, high local recharge and young water, are consistent.

Figure 15 shows plots of the relative ${ }^{13} \mathrm{C} /{ }^{12} \mathrm{C}$ content $\left(\delta^{13} \mathrm{C}\right)$ of aqueous carbonate in these same waters as a function of the total carbonate content. The $\delta^{13} \mathrm{C}$ data can provide some information about the origin of the carbonate (Faure 1977; Fritz and Fontes 1980; Haas et al. 1983; Thorstenson et al. 1983; Wigley et al. 1978). In particular, paleozoic carbonates have a $\delta^{13} \mathrm{C}$ value of $\sim-2 \%$, atmospheric carbon dioxide has a $\delta^{13} \mathrm{C}$ value of $\sim-7$ to $-9 \%$, and soil-zone carbon dioxide that is derived from plants has $\delta^{13} \mathrm{C}$ values of $\sim-12$ to $-25 \%$. Some care must be taken in comparing $\delta^{13} \mathrm{C}$ values of gas, aqueous, and solid phases because of fractionation; thus, carbon dioxide gas will have a different $\delta^{13} \mathrm{C}$ than the carbonate in an aqueous phase in equilibrium with it (Wigley et al. 1978). Figure 15(a) stiows data for 55 samples from Yucca Mountain, NTS, and vicinity. As with the ${ }^{14} \mathrm{C}$ data (PMC) in Fig. 14, there are two trends apparent in Fig. 15(a). The data from Oasis Valley, although scattered, show a decrease in $\delta^{13} \mathrm{C}$ with increasing carbonate. This trend is consistent with the variation of PMC with carbonate; soil-zone carbonate that is added to the aqueous phase or exchanges with aqueous carbonate is derived from plant respiration and has more negative $\delta^{13} \mathrm{C}$ than the original carbonate in the water. The data from Yucca Mountain and vicinity (see also Fig. 15(b) show a range of $\delta^{13} \mathrm{C}$ values $(-13 \%$, to $-7 \%$ ) at about 2 moles $/ 1$ total carbonate, with some tendency to more positive $\delta^{13} \mathrm{C}$ with increasing carbonate. Only one tuffaceous aquifer well from Yucca Mountain (USW 4 j) has a $\delta{ }^{13} \mathrm{C}$ value above about $-7 \%$. As with PMC, it is not clear whether there is a connection between the tuffaceous water data and the UE-25p\#1 data. If there is a connection, the increase in $\delta^{l} \mathrm{C}$ with increasing carbonate could be caused by the addition of carbonate aquifer water to the tuffaceous aquifer. 

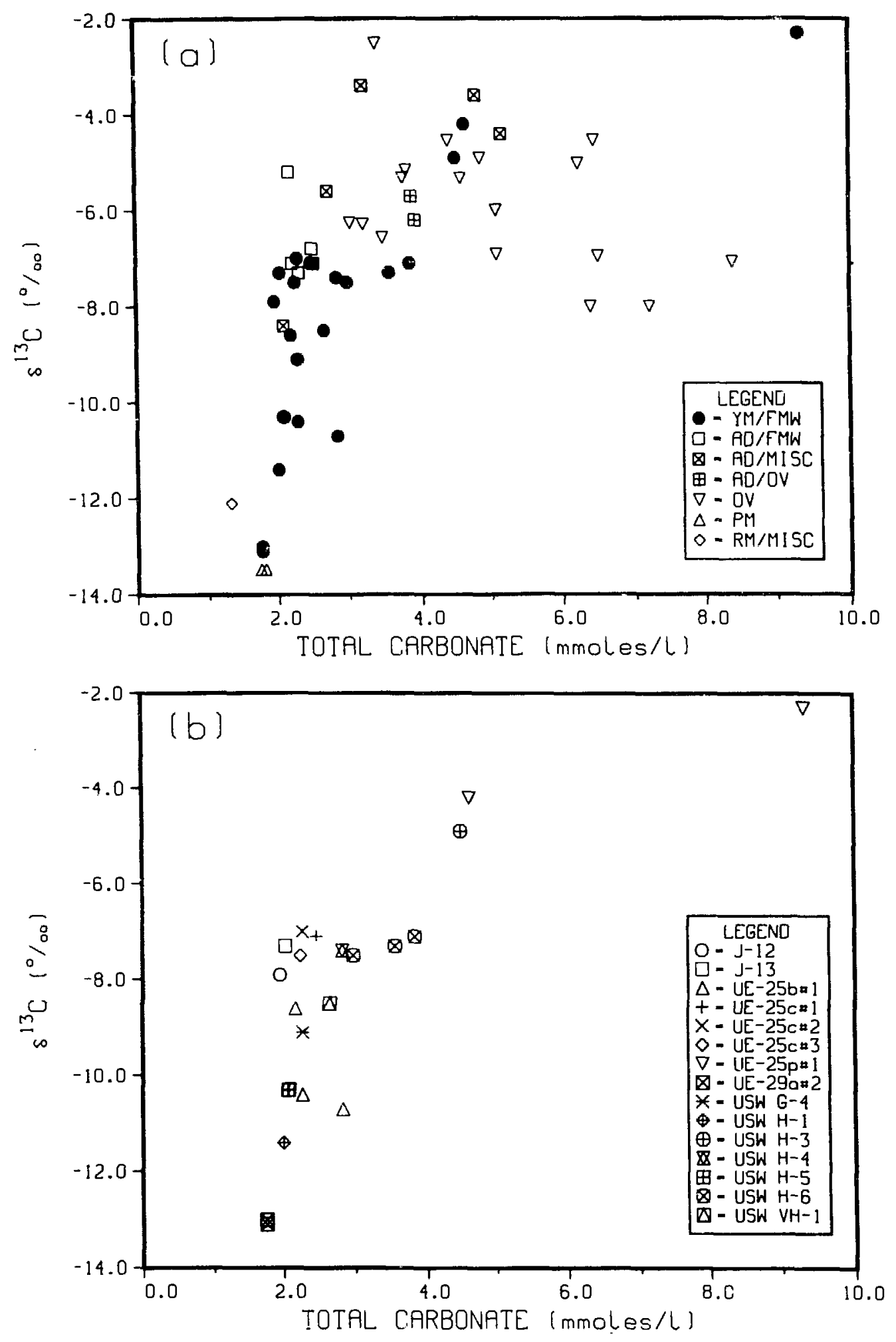

Fig. 15. $\delta^{13} \mathrm{C}$ as a function of total carbonate content.
a. All sampling locations (see Table II for meaning of legend abbreviations).
b. Yucca Mountain and vicinity. 
The relation between $\mathrm{pH}$ and total carbonate shown in Fig. 7, and the relations between PMC and total carbonate and between $\delta^{13} \mathrm{C}$ and total carbonate shown in Figs. 14(b) and 15(b), imply a relation between $\mathrm{pH}$ and the isotopic variabies. Figure 16(a) shows a plot of $\mathrm{pH}$ as a function of PMC and Fig. 16(b) shows a plot of $\mathrm{pH}$ as a function of $\delta^{13} \mathrm{C}$ for water from Yucca Mountain and vicinity. Both plots show some trends in the data for the tuffaceous waters, but the UE-25p\#l samples do not follow these trends. This disparity between the UE-25p\#l data and the tuffaceous water data was also evident in plots of $\mathrm{PH}$ and carbon dioxide pressure as a function of total carbonate (Figs. 7 and 9 ), and calcite $\log _{10}(\mathrm{Q} / \mathrm{K})$ as a function of $\mathrm{pH}$ (Fig. 10). This behavior contrasts $t$ th the apparent continuity between the UE-25p\#1 data and tuffaceous data in plots of calcium content and carbon dioxide pressure as a function of pH (Figs. 6 and $8(b)$ ) and of PMC and $\delta^{13} \mathrm{C}$ as a function of total carbonate (Figs. $14 i b$ ) and $15(b)$ ). Although some data point to a connection between the tuffaceous and carbonate waters at Yucca Mountain, it is far from clear that an actual physical or chemical connection exists (see Section VII $(B))$.

Stable hydrogen and oxygen isotopic data can also provide information about the origins of water or some of the physical and chemical processes that the water has undergone (Craig 1961; Faure 1977; Dansgaard 1964; Fritz and Fontes 1980). Figure $17(a)$ shows a plot of the relative deuterium/hydrogen content ( $8 D$ ) of water from Yucca Mountain, NTS, and vicinity as a function of the relative ${ }^{18} 0 /{ }^{16} 0$ content $\left(\delta^{18} 0\right)$. The straight line represents a relation obtained by Craig (1961) for meteoric water. Claassen (1985) shows a similar plot (with only some of the data) and interprets the distribution of the data along the meteoric water line as a temperature effect, with more negative $\delta D$ and $\delta^{18} 0$ originating as precipitation at lower temperatures. Claassen (1985) also shows relations between $\delta D$ and $\delta^{18} 0$, and apparent age, with older waters (lower PMC) showing more negative $S D$ and $\delta^{18} 0$. He relates this to colder temperatures 10,000 to 15,000 years ago (see also the following paragraph). White and Chuma (1986) reported the data from Pahute Mesa and Oasis Valley in Fig. $17(d)$. They interpreted the spread in Oasis Valley as caused by a mixing of Pahute Mesa water $\left(\delta D=\sim-114 \%\right.$ and $\delta{ }^{18} \mathrm{O}=\sim-14.5$ to $-14.7 \%$ \% with water from the Bullfrog Hills in Oasis Valley $\left(80=\sim-102 \%\right.$ and $\delta^{18} \mathrm{O}=$ $\sim-13.4 \%$ \%). They also cite the difference between Pahute Mesa water and water from Fortymile Wash and the portion of the Amargosa Desert that drains 

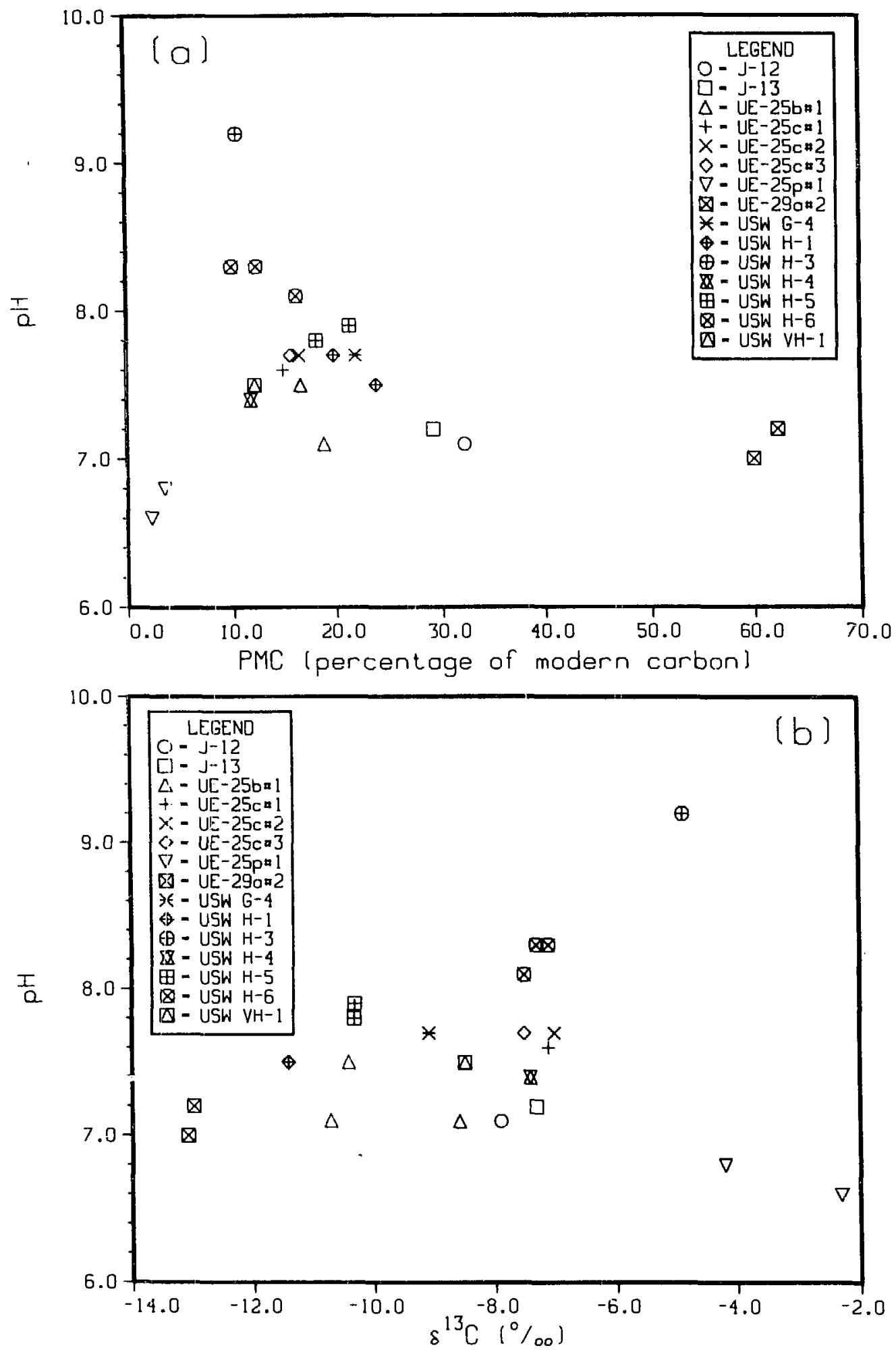

Fig. 16. The pH as a function of the percentage of modern carbon and $\delta^{13} \mathrm{C}$ at Yucca Mountain and vicinity.

a. $\mathrm{pH}$ as a function of the percentage of modern carbon.

b. $\mathrm{pH}$ as a function of $\mathrm{s}^{13} \mathrm{C}$. 

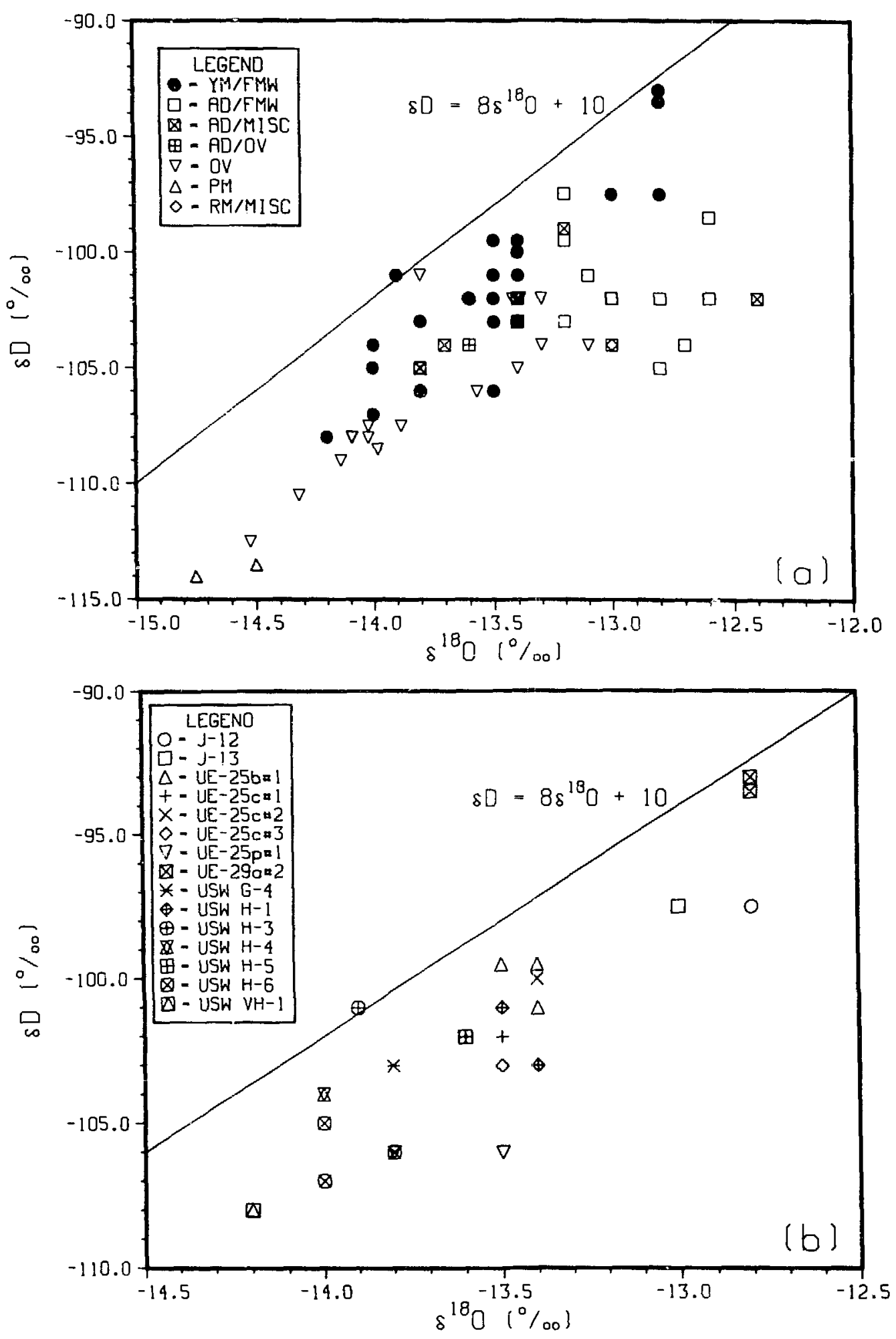

Fig. 17. $\delta 0$ as a function of $\delta^{18} 0$.
a. All sampling locations (see Table II
for meaning of legend abbreviations).
b. Yucca Mountain and vicinity. 
Fortymile Wash as evidence that Pahute Mesa is not a recharge area for Fortymile wash. Figure $17(b)$ shows a plot of $\delta D$ as a function of $\delta{ }^{18} 0$ for water from Yucca Mountain and vicinity only. The wells from Fortymile Wash $\left(J-12, J-13\right.$, and UE-29a $\$ 2$ ) plot at more positive $\delta D$ and $\delta^{18} 0$ than the Yucca Mountain wells, consistent with that water originating as precipitation at higher temperatures or lower elevations (Dansgaard 1964; Fritz and Fontes 1980).

The relation between $\delta D$ and apparent age reported by Claassen (1985) for water from the Amargosa Desert also holds for Yucca Mountain. Figure 18(a) shows a plot of $\delta D$ as a function of PMC for water from Yucca Mountain and vicinity. Water with lower values of PMC (older apparent age) has more negative values of $\delta D$, indicating it originated as precipitation at lower temperatures or at higher elevations. Because PMC and the total carbonate content of water from Yucca Mountain are related (see Fig. 14(b)), there is also a relation between $\delta D$ and total carbonate; this is shown in $F i g . ~ 18(b)$, where increasing carbonate content above about 2 moles/l leads to more negative values of $\delta D$. Both plots show scatter; however, the relationship between $\delta D$ and PMC (Fig. 18(a)) seems to be better defined. This leaves two possible explanations for the range of 60 values observed: that it is a temperature effect with older water originating as precipitation at lower temperatures (Claassen 1985) or that it is a mixing of waters with different vaiues of $\delta D$. Some combination of these two limiting cases is also possible.

Tritium is a radioactive isotope of hydrogen that is sometimes useful for dating water (Fritz and Fontes 1980). Because of its short half-life (12.3 yr), water isolated from atmospheric sources of tritium would not contain measurable levels after about $100 \mathrm{yr}$. Before atmospheric testing, the natural tritium content of precipitation was less than about $60 \mathrm{pCi} / 1$; atmospheric testing of nuclear weapons increased tritium contents of precipitation by several orders of magnitude (Fritz and Fontes 1980). The tritium contents of water from a number of wells at Yucca Mountain (Benson and McKinley 1985) and around NTS (Clebsch 1961; Claassen 1973) have been reported. Most of the results represent tritium contents below detection limits of the analysis, however some analyses have reported measurable tritium contents. Clebsch (1961) found detectable tritium in whiterock Spring and in water from a tunnel at Rainier Mesa; tritium was not detected in water from a number of wells around NTS. Claassen (1973) reported detectable tritium 

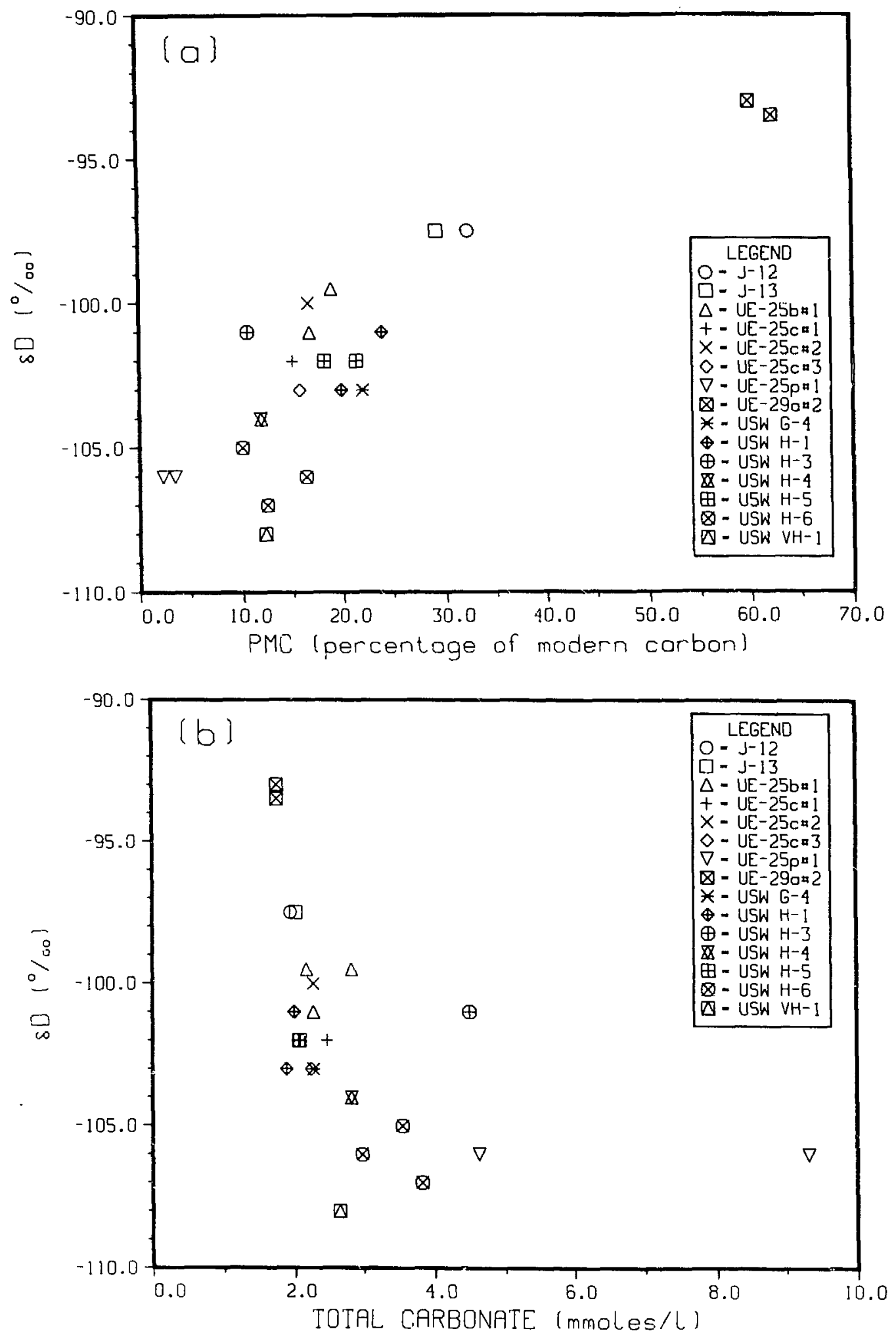

Fig. 18. $\delta D$ as a function of the percentage of modern carbon and total carbonate content at Yucca Mountain and vicinity. a. $\delta D$ as a function of the percentage of modern carbon. b. $\delta D$ as a function of total carbonate content. 
levels in water from a number of NTS water-supply wells during a 1964 survey; levels of 1000 to $2500 \mathrm{pCl} / 1$ (300 to 800 tritium units) were measured for some wells, but most wells had much lower levels. Benson and Mckinley (1985) reported detectable tritium levels in six wells from Yucca Mountain and vicinity, UE-25b\#1 (2 pCi/1), UE-25C\#3 $(2 \mathrm{pCl} / 1), \mathrm{UE}-25 \mu \# 1$ carbonate water $(10$ $\mathrm{pCl} / 1)$, UE-29a\#2 (37 pCi/1), USW $\mathrm{H}-3(2 \mathrm{pCi} / 1)$, and USW $\mathrm{H}-6(1-4 \mathrm{pCl} / 1)$. The highest tritium level around Yucca Mountain is from the shallow (29-m depth to static water level) Well UE-29a\#2 in Fortymile Wash; th!s well also has the highest value of PMC (youngest apparent age) of these wells. The meaning of measurable tritium levels in water from deep wells (over 100-m depth to static water level) is uncertain. If they are representative of the water at depth, they imply a connection that allows fast transport (less than $100 \mathrm{yr}$ ) between an atmospheric source of tritium and the saturated zone, or a source of tritium at depth. Low but measurable levels of tritium may also result from sample contamination.

\section{Other Specles and Varlables}

In addition to the discussions of major species and isotopic data presented above, there are a number of minor species or other variables that are important or that show some interesting relationships. This section discusses nitrate, fluoride, organic and particulate concentrations, and water temperature.

Analyses for nitrate are often not done. Only about a quarter of the water samples revlewed here had nitrate contents reported; however, two-thirds of the samples from Yucca Mountain and vicinity included nitrate data. The nitrate content of all the waters as a group did not show any relationship with other compositional variables, but the data from Yucca Mountain and vicinity did. Figure $19(\mathrm{a})$ shows a plot of nitrate content of water from Yucca Mountain and vicinity as a function of PMC. Figure 19(b) shows nitrate content as a function of total carbonate. The behavior of nitrate content as a function of these varlables shows the same general trends as that of $\delta D$ (see Figs. 18). For these wells, low nitrate content is associated with low PMC (older apparent age) and, to some extent, with higher total carbonate

\footnotetext{
*In their report on UE-25p\$1, Craig and Robison (1984) quoted tritium levels less than $10 \mathrm{pCi} / 1$ for both carbonate water and mixed tuffaceous-carbonate water; thus, the report of $10 \mathrm{pCl} / 1$ for UE-25p\#1 carbonate water in Benson and MCKinley (1985) may be a misprint.
} 

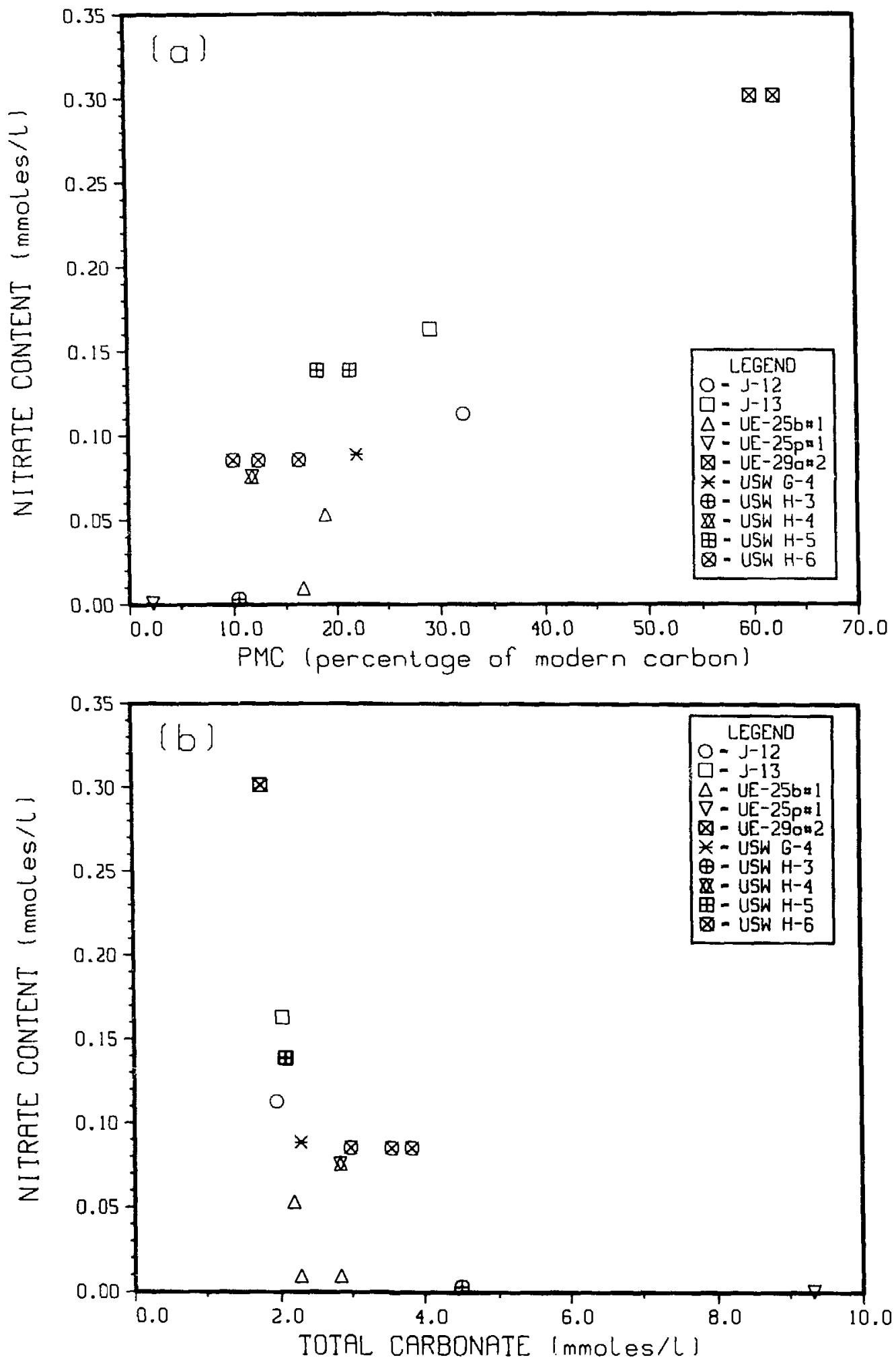

Fig. 19. Nitrate content as a function of the percentage of modern carbon and total carbonate content at Yucca Mountain and vicinity.

a. Nitrate content as a function of the percentage of modern carbon.

b. Nitrate content as a function of total carbonate content. 
content. High nitrate content in water is usually associated with surface contamination such as fertilizers or sewage, or with shallow wells (Feth 1966). The well with the highest nitrate content in Figs. 19 (UE-29a\#2) is very shallow (29-m depth to water (Benson and McKinley 1985)), compared to the other wells around Yucca Mountain (180- to over 700-m depth to water (Robison 1984)). Data on nitrate contents were unavailable for most other waters examined here; data were reported for some wells from NTS (Claassen 1973) and Pahute Mesa (Blankennagel and Weir 1973). The data from Pahute Mesa showed low nitrate contents (less than 0.05 mmoles/l); the data from wells in Yucca Flat and Frenchman Flat showed higher nitrate contents (up to 0.2 mmoles/1). A survey of 950 groundwater analyses around the United States showed that two-thirds were in the 0 - to 0.15 -mmoles/1 range (Feth 1966). This range covers all the water from around Yucca Mountain except UE-29a\#2. Based on this comparison, the presence of nitrate in the water and the range of nitrate concentrations observed at Yucca Mountain are not unusual.

Data on fluoride contents are available for about half the water samples reviewed here; all of the samples from Yucca Mountain and vicinity included fluoride data. The fluoride content of all the water samples taken together did not seem to be strongly correlated with other compositional variables, however there was a tendency for increasing fluoride content with increasing sodium and carbonate contents and relative sodium content $(\mathrm{Na} /(\mathrm{Na}+\mathrm{Ca}+\mathrm{K}))$. Considering only the data from Yucca Mountain and vicinity, there is a nearly linear relation between fluoride content and sodium and carbonate contents. Figure 20(a) shows a plot of fluoride content of water from Yucca Mountain and vicinity as a function of sodium content and Fig. 20(b) shows fluoride content as a function of total carbonate content. The wells with high sodium and carbonate contents also have high fluoride contents. The carbonate water from UE-25p\#l does not fit the fluoride-carbonate relation well (see Fig. 20(b)). Ogard and Kerrisk (1984) also showed a tendency for $\mathrm{F}^{-} /\left(\mathrm{F}^{-}+\mathrm{Cl}^{-}\right)$to increase with increasing $\mathrm{Na} /(\mathrm{Na}+\mathrm{Ca}+\mathrm{K})$ for water from Yucca Mountain. EQ3 calculations of fluorite $\log _{10}(Q / K)$ for 56 water samples from Yucca Mountain, NTS, and vicinity gave values from -3 up to 0.5 . Two wells from Yucca Mountain and vicinity (UE-25p\#1 carbonate water and USW H-4) were supersaturated with respect to fluorite; other supersaturated waters were from Oasis Valley and Painute Mesa. Waters with both phosphate and fluoride concentrations reported (Claassen 1973) were highly supersaturated with respect to fluorapatite. 

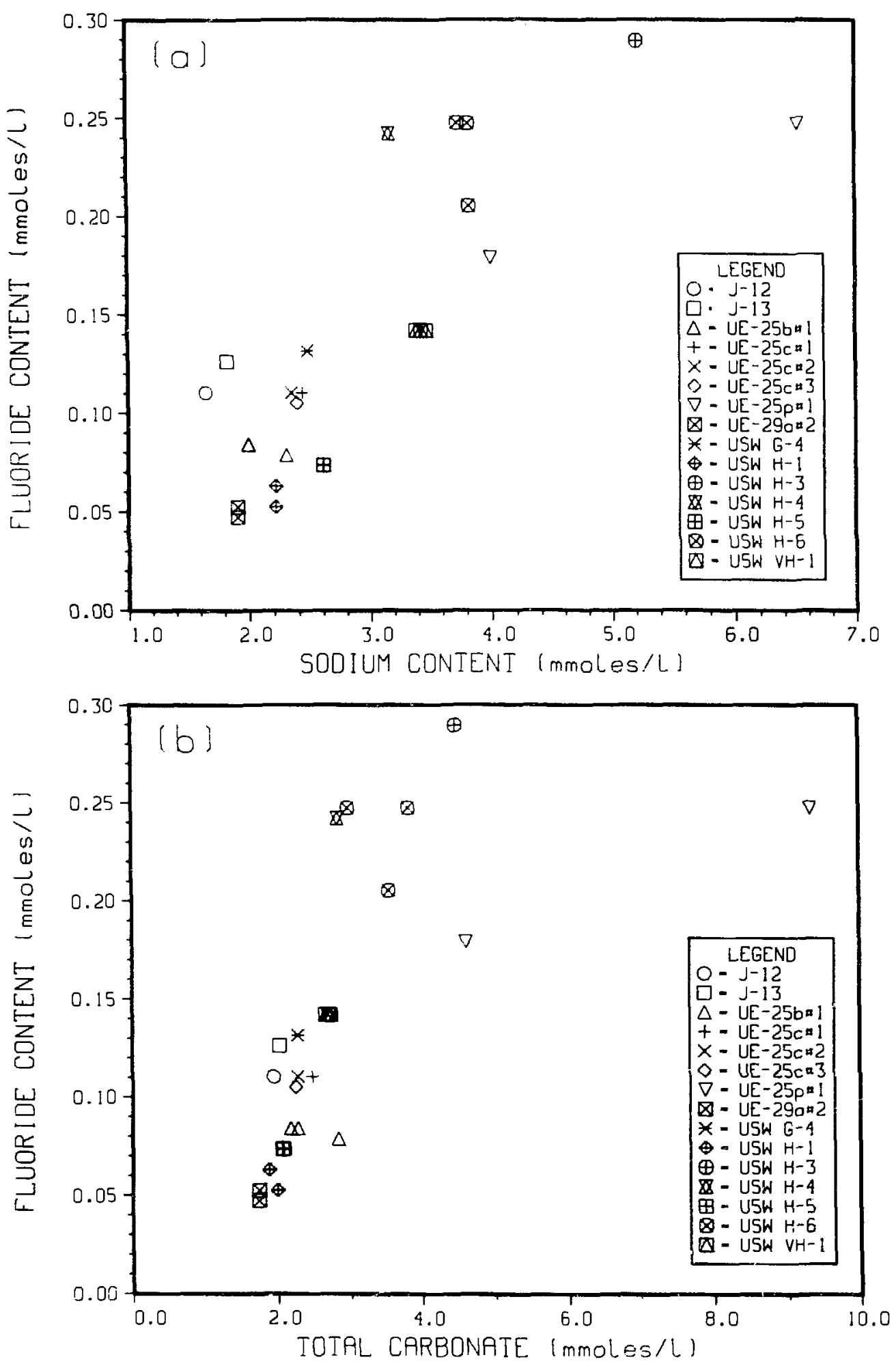

Fig. 20. Fluoride content as a function of sodium content and total carbonate at Yucca Mountain and vicinity.

a. Fluoride content as a function of sodium content.

b. Fluoride content as a function of total carbonate content. 
The organic contents of water from two wells at Yucca Mountain and vicinity were reported by Means et al. (1982). No other organic analyses were found for water from Yucca Mountain, NTS, and vicinity. The total organic carbon content of Well J-13 water was $0.15 \mathrm{mg} / 1$, and of UE-25b\#1 water was $0.55 \mathrm{mg} / 1$. About $50 \%$ of the organic content of $\mathrm{J}-13$ water and $33 \%$ of the organic content of UE-25b\#1 water were high molecular-weight organics (molecular weight greater than 1000). The organic content of $3-13$ water is probably more representative of conditions in the saturated zone because it is a producing well and all drilling fluids have been removed by extensive pumping. At this time, there are not enough data on the organic contents of water from Yucca Mountain and vicinity to attempt to relate organic concentrations to other compositional or physical variables. The low levels of organics may make further investigation unnecessary.

Particulate material, although in suspension rather than in solution, can significantly affect concentrations of dissolved material. The particulate content of water from only one well near Yucca Mountain (Well J-13) has been examined. This well was chosen because it has been used for over 20 years and the particulate material produced during drilling should no longer contaminate the water. Water from Well J-13 was pumped through filters during a 14-day test. Two size fractions of solids were collected, >0.4 $\mu \mathrm{m}$, and $5 \mathrm{~nm}$ to $0.4 \mu \mathrm{m}$. Based on the quantity of water filtered and the mass of solids collected, the average concentration of the larger size fraction was approximately $3 \times 10^{-5} \mathrm{~g}$ solids/l water; the smaller size fraction was estimated to be present as approximately $6 \times 10^{-7} \mathrm{~g}$ solids/l water. Analysis of the cation content of the larger size fraction showed 60 wt\% silicon, 20 wt\% iron, 11 wt\% calcium, and 4 wt\% aluminum. The smaller size fraction contained 44 wt\% sodium, $42 w t \%$ silicon, $8 w t \%$ calcium, and $4 w t \%$ iron. Aside from the tron, these compositions could easily result from particulates of local minerais. The relatively large amount of iron in both groups may result from particulate material from the pumping and piping system of the well. A more. complete description of this work, along with a discussion of the possible influence of particulate concentrations at this level on radionuclide transport. is contained in Appendix $B$ of this report. There are no other data on particulate concentrations in water from Yucca Mountain. NTS, and vicinity available for comparison. 
As expected, the temperature of water from wells at Yucca Mountain, NTS, and vicinity tends to increase with increasing depth of the water sample. In addition to this variation, the temperature of water from wells at Yucca Mountain and vicinity is correlated with PMC and total carbonate content of the water (see Figs. $21(a)$ and $21(b)$ ). Part of this relation is from water sample depth. For example, the carbonate water from UE-25p\#1 is the deepest sample, has the lowest PMC, and has the highest temperature; water from UE-29a\#2 is the shallowest sample, has the highest PMC, and has the lowest temperature. However, for the intermediate samples, water temperature is not a function of sample depth, well depth, or depth to the static water level. Water from $\mathrm{H}-3$ seems to have an anomalously low temperature (see Figs. 21). The trends of temperature with PMC and carbonate content seen in Figs. 21 are similar to the trends of $\delta^{13} \mathrm{C}, \mathrm{pH}$, and fluoride content seen in Figs. $15(\mathrm{~b})$, $16(a)$, and $20(b)$.

\section{Relations with Location or Depth}

During a discussion of the relative sodium content $(\mathrm{Na} /(\mathrm{Na}+\mathrm{Ca}+\mathrm{K}))$ of water from Yucca Mountain and vicinity (Section VI $(A)$ ), a relation between relative sodium content and well location was mentioned. Figure 22 shows a map of the Yucca Mountain area with locations of wells near the Exploration Block shown; associated with each well is a value or range of values of $\mathrm{Na} /(\mathrm{Na}+\mathrm{Ca}+\mathrm{K})$ for that well. There is a definite east to west trend in this variable. Wells west of the Ghost Dance Fault (USW H-3, H-5, and $\mathrm{H}-6$ ) show high relative sodium content, 0.94 to 0.98 , compared to wells directly to the east of the fault (USW G-4, H-4, and UE-25b\#1), 0.69 to 0.79 . This trend of low relative sodium content in the east and high in the west also includes the other Yucca Mountain wells. The high relative sodium content of water from wells west of the Ghost Dance Fault is more a result of the low calcium content of these waters that was noted in Section VI(A) than from a high sodium content (see Fig. 23). The reasons for the trends in calcium and sodium content are not evident from these data alone.

Figure 24 shows a map of the Yucca Mountain area in which the 'cotal carboriate contents are noted. Wells to the south and west (USW $\mathrm{H}-3, \mathrm{H}-4$, and H-6) tend to have higher carbonate contents than wells to the north and east. This trend is not as well defined as that noted above for relative sodiuril content. In particular, the Ghost Dance Fault no longer represents a dividing line for these data. Because of the relations beteen PMC and $\delta^{13} \mathrm{C}$ and the 

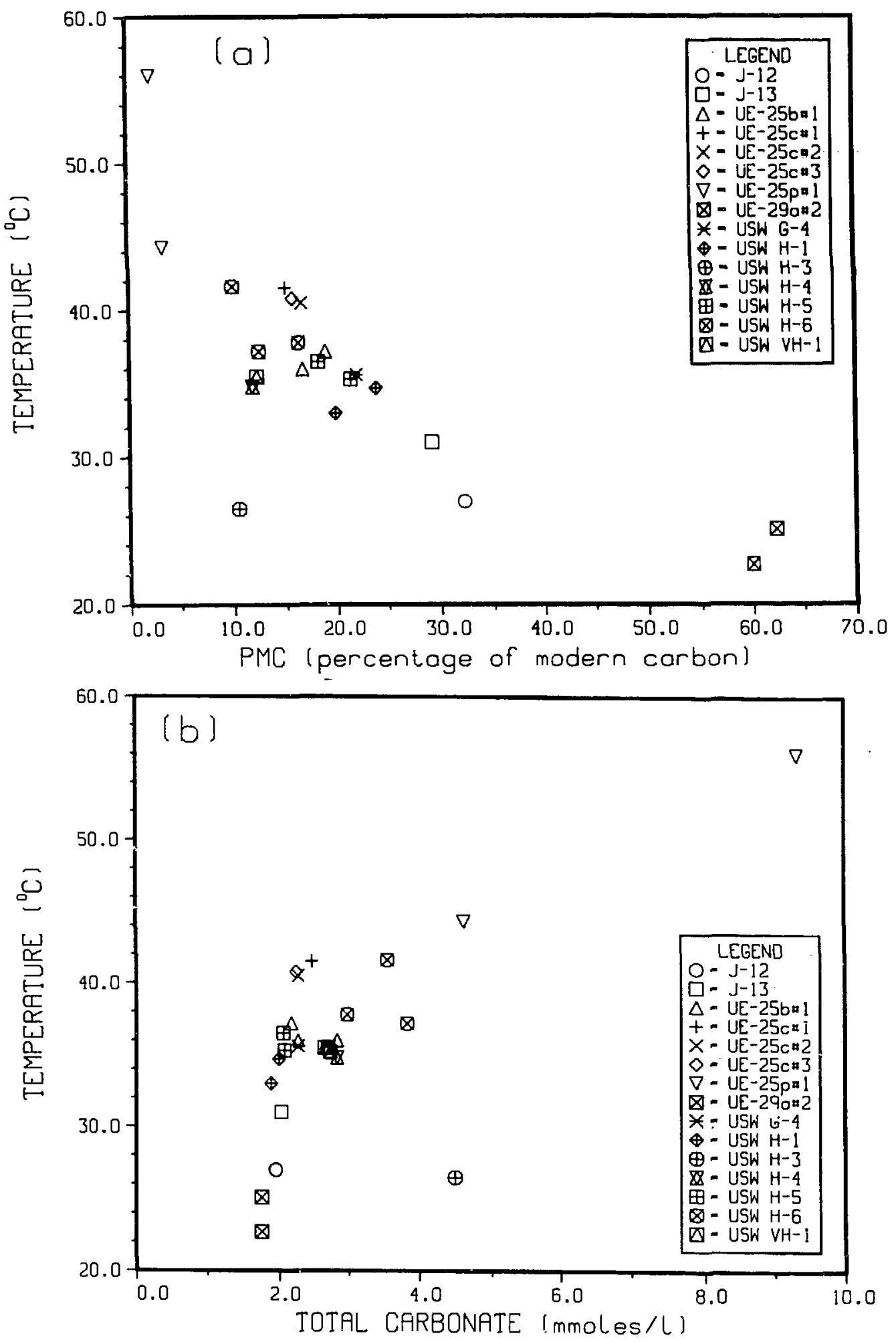

Fig. 21. Water temperature as a function of the percentage of modern carbon and total carbonate content at Yucca Mountain and vicinity.

a. Water temperature as a function of the percentage of modern carbon.

b. Water temperature as a function of total carbonate. 


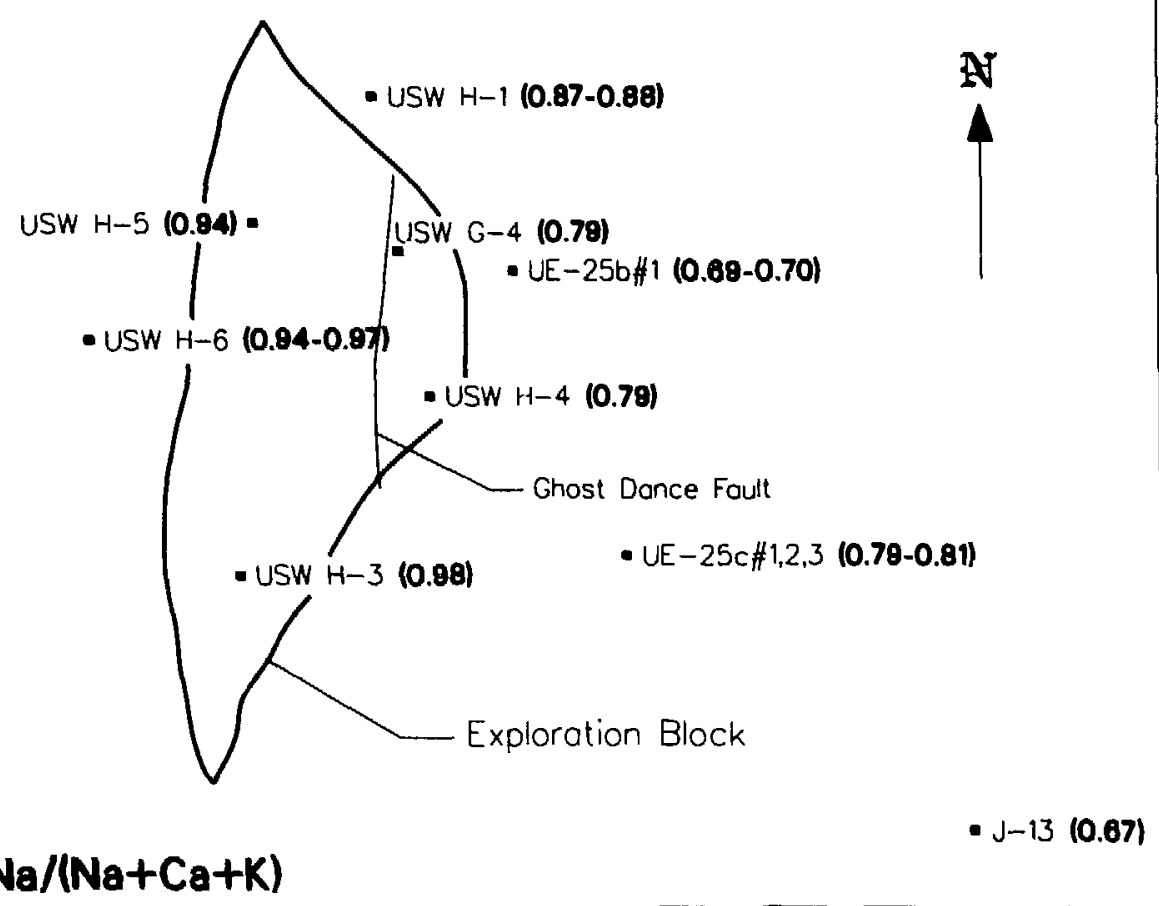

Fig. 22. $\mathrm{Na} /(\mathrm{Na}+\mathrm{Ca}+\mathrm{K})$ as a function of location for wells near Yucca Mountain.

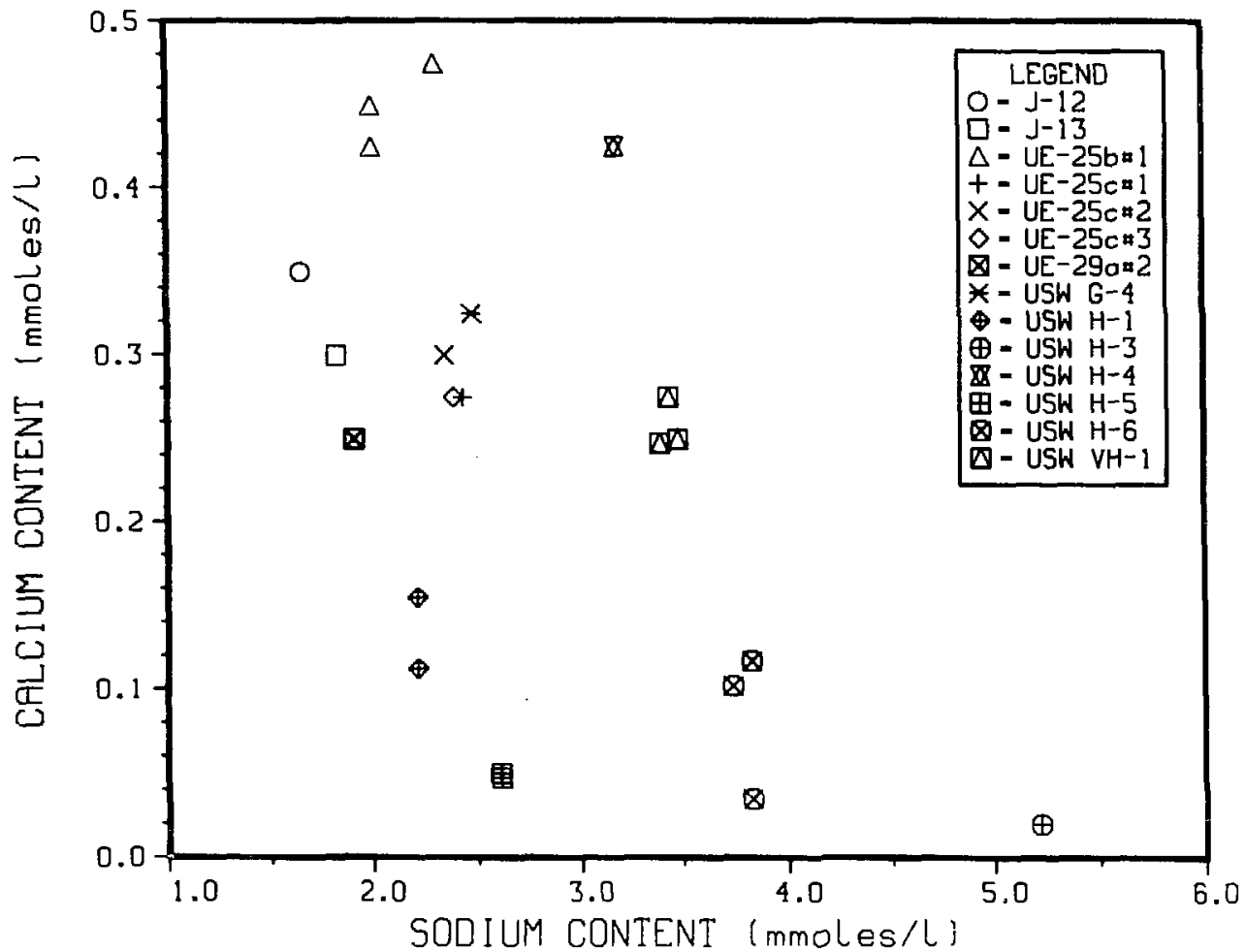

Fig. 23. Calcium content as a function of sodium content at Yucca Mountain and vicinity. 


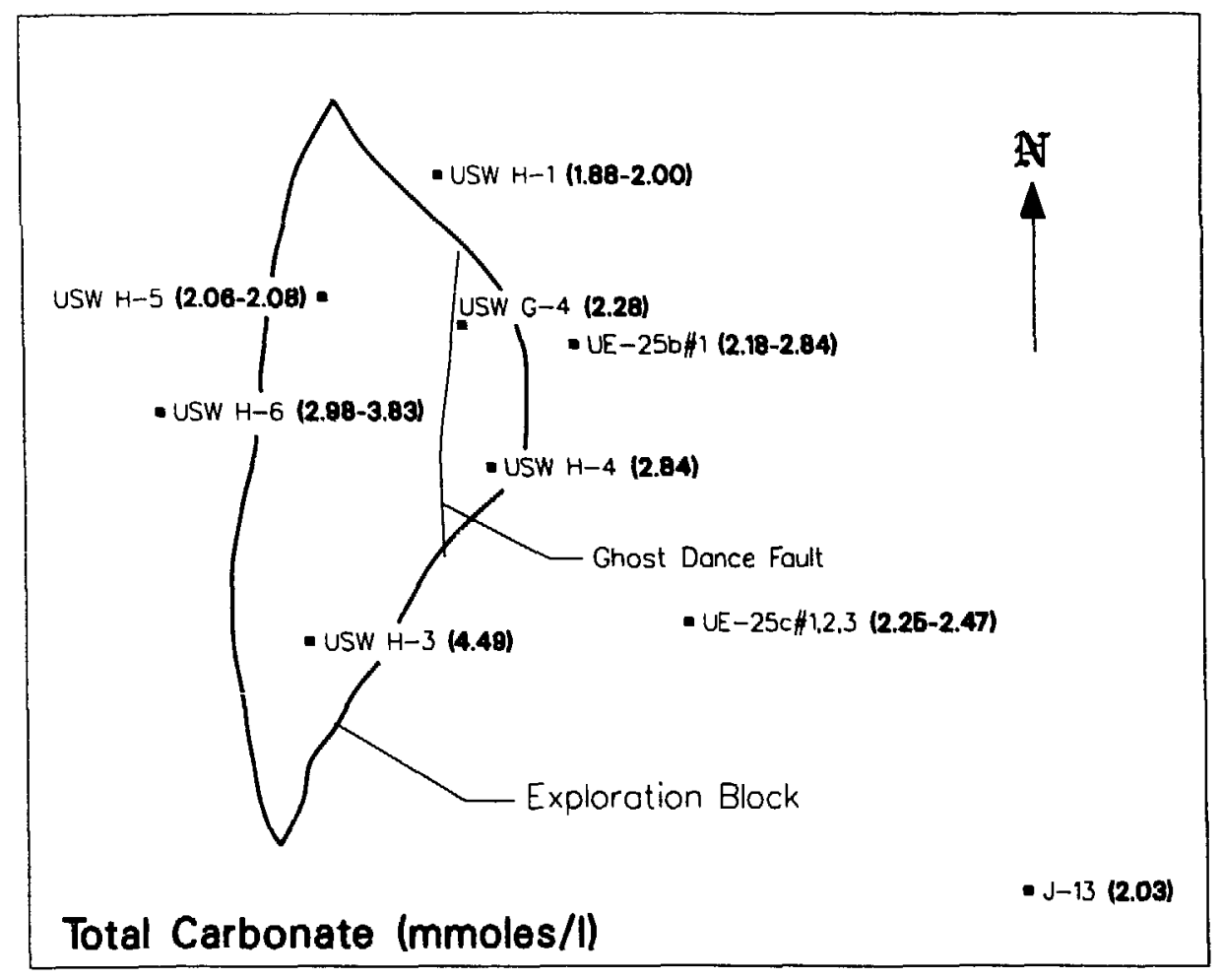

Fig. 24. Total carbonate content as a function of location for wells near Yucca Mountain.

total carbonate content for wells at Yucca Mountain (see Figs. 14(b) and $15(b))$, both PMC and $\delta^{13} \mathrm{C}$ show trends with location that are similar to that of total carbonate as seen in Fig. 24. The fluoride content of waters from Yucca Mountain also shows a trend with location that is similar to the total carbonate trend; that is, Wells USW $\mathrm{H}-3, \mathrm{H}-4$, and $\mathrm{H}-6$ are high in fluoride compared to other nearby wells to the northeast. The relation between fluoride content and total carbonate was discussed in Section VI(C) and shown in Fig. 20(b). As with the trends in cation concentrations noted above, the reasons for the trends in carbonate content and associated variables are uncertain at this time.

Five wells at Yucca Mountain and vicinity have been pumped from two packed-off intervals or from one interval and the entire well bore (integral sample). Compositional variables from these five wells were examined to look for trends with depth. Table III lists the depth intervals sampled and the values of four variables ( $\delta 0, P M C, \delta^{13} \mathrm{C}$, and total carbonate) at these 
TABLE III

VARIATION OF WATER PROPERTIES WITH DEPTH

\begin{tabular}{|c|c|c|c|c|}
\hline $\begin{array}{l}\text { Parameter } \\
\text { Depth } \\
\text { Interval } \\
\text { Sampled } \\
(\mathrm{m})\end{array}$ & $\begin{array}{l}\frac{\mathrm{We} 11}{\mathrm{UE}-25 \mathrm{b \# 1}} \\
\text { UE-25p\#1 } \\
\text { UE-29a\#2 } \\
\text { USW H-1 } \\
\text { USW H-6 }\end{array}$ & $\begin{array}{l}\text { Integrala } \\
\text { Sample } \\
\text { Yes } \\
\text { No } \\
\text { No } \\
\text { No } \\
\text { Yes }\end{array}$ & $\begin{array}{l}\text { Shal low } \\
\text { Interval } \\
\text { No } \\
381-1197 \\
87-213 \\
572-687 \\
608-646\end{array}$ & $\begin{array}{c}\text { Deep } \\
\text { Interval } \\
863-875 \\
1297-1805 \\
247-354 \\
687-1829 \\
753-835\end{array}$ \\
\hline $\begin{array}{l}\delta D \\
(\% / 00)\end{array}$ & $\begin{array}{l}\text { UE-25b\#1 } \\
\text { UE-25p\#1 } \\
\text { UE-29a\#2 } \\
\text { USW H-1 } \\
\text { USW H-6 }\end{array}$ & $\begin{array}{c}-99.5 \text { to }-101 \\
- \\
- \\
-\overline{106}\end{array}$ & $\begin{array}{r}-106 \\
-93 \\
-103 \\
-107\end{array}$ & $\begin{array}{l}-99.5 \\
-106 \\
-93.5 \\
-101 \\
-105\end{array}$ \\
\hline $\begin{array}{l}\text { PMC } \\
(\%)\end{array}$ & $\begin{array}{l}\text { UE-25b\#1 } \\
\text { UE-25p\#1 } \\
\text { UE-29a\#2 } \\
\text { USW } H-1 \\
\text { USW H-6 }\end{array}$ & $\begin{array}{c}16.7 \\
- \\
- \\
16.3\end{array}$ & $\begin{array}{r}- \\
3.5 \\
60.0 \\
19.9 \\
12.4\end{array}$ & $\begin{array}{r}18.9 \\
2.3 \\
62.3 \\
23.9 \\
10.0\end{array}$ \\
\hline $\begin{array}{l}\delta^{13} \mathrm{C} \\
(0 / 00)\end{array}$ & $\begin{array}{l}\text { UE-25b\#1 } \\
\text { UE-25p\#1 } \\
\text { UE-29a\#2 } \\
\text { USW H-1 } \\
\text { USW H-6 }\end{array}$ & $\begin{array}{c}-10.4 \text { to }-10.7 \\
- \\
- \\
- \\
-7.5\end{array}$ & $\begin{array}{r}-\overline{4} .2 \\
-13.1 \\
\overline{-} .1\end{array}$ & $\begin{array}{r}-8.6 \\
-2.3 \\
-13.0 \\
-11.4 \\
-7.3\end{array}$ \\
\hline $\begin{array}{l}\text { Total } \\
\text { Carbonate } \\
\text { (mmoles } / 1)\end{array}$ & $\begin{array}{l}\text { UE-25b\#1 } \\
\text { UE-25p\#1 } \\
\text { UE-29a\#2 } \\
\text { USW H-1 } \\
\text { USW H-6 }\end{array}$ & $\begin{array}{c}2.3-2.8 \\
- \\
- \\
3.0\end{array}$ & $\begin{array}{l}- \\
4.6 \\
1.8 \\
1.9 \\
3.8\end{array}$ & $\begin{array}{l}2.2 \\
9.3 \\
1.8 \\
2.0 \\
3.6\end{array}$ \\
\hline
\end{tabular}

dentire well bore pumped.

intervals. The variation of some variables (PMC, $\delta^{13} \mathrm{C}$, and total carbonate) for UE-25p\#1 is understandable because the deep interval sampled the carbonate aquifer and the shallow interval sampled a mixture of carbonate and tuffaceous water (Craig and Robison 1984). However, there is no obvious trend in the data for the other four wells, which sample the tuffaceous aquifer at all the intervals sampled. The same conclusion holds for other compositional variables not listed in Table III. 
During a 28-day pumping test of the 863-875 m packed-off interval (Bullfrog Member) of UE-25b\#1, a significant variation in a number of the compositional variables was observed (Daniels et al. 1983; Rundberg et al. 1985). Dissolyed oxygen and Eh increased and total iron, manganese, and nitrite decreased with time after the first few days; alkalinity also showed a slight drop. Major cation concentrations were relatively constant. One possible explanation for these results is that the water sampled early in the test is representative of the interval pumped, but with continued pumping, water was being drawn from other vertical locations (Daniels et al. 1983). If this is true, the significance of pumping packed-off intervals to investigate variation of water composition with depth at Yucca Mountain is uncertain. Similar pumping tests of two intervals from Weil USW H-6, the 608- to 646-m interval (Bullfrog Member) and the 753- to 835-m interval (Tram Unit), gave water compositions that were essentially constant with time and very similar (Ogard and Vaniman 1985).

Another technique was used to sample wells USW H-l and H-4 cogard and Kerrisk 1984). Water samples were taken from static holes after the completion of pumping tests by lowering evacuated, stainless-steel bottles to selected depths. (These samples were already mentioned in Section VI(A) during the discussion of redox conditions.) The USW H-l samples were taken at four depths, about a year after the pumping test was completed. Concentrations of some major species varied considerably from sample to sample (factors of 2 to 4 for calcium, potassium, silicon, chloride, and sulfate); the static-sample compositions also differed from the integral sample taken during the pumping test on this well. There was no consistent variation in the USW H-l static samples with depth. The USW H-4 static samples were taken at eight depths, about a week after completion of the pumping test. Concentrations of the major species were similar at all depths and generally similar to the integral sample taken during the pumping test. The similarity of all the USW H-4 compositions may result from mixing during pumping that did not have time to equllibrate with local formation water in one week. Ogard and Kerrisk (1984) did not interpret the static sample compositions in terms of the water chemistry; they recommended further static sampling as a function of time after the completion of pumping tests before interpretation.

There are two reports of measurements of water compositions of near surface water (within a few meters of the surface) in conjunction with 
measurements at depth. At Rainier Mesa, Benson (1976) measured compositions of two surface samples along with pore-water compositions at 130 - to 530-m depth. Also at Rainier Mesa. Henne (1982) measured surface water compositions and fracture water compositions from tunnel samples. Figure 25 (a) shows a ternary plot of the sodium-calcium-potassium composition of the water analyzed by Benson (1976), separated into surface samples and two depth intervals. Figure 25(b) shows a similar plot for the data of Henne (1982), separated into surface samples and samples at depth. In both cases there is a tendency toward increasing relative sodium content $(\mathrm{Na} /(\mathrm{Na}+\mathrm{Ca}+\mathrm{K}))$ with increasing depth. This is also a tendency toward increasing maturity of water in the process of glass and mineral dissolution and secondary mineral precipitation (White et al. 1980; Kerrisk 1983; Claassen 1985). As noted in Section VI(A) in the discussion of aqueous silica, the surface samples taken by Benson (1976) and Henne (1982) also have about half the aqueous silica content of waters at depth. This bias also indicates that dissolution continues with increasing depth. The two surface samples analyzed by Benson (1976) had much lower chloride and sulfate contents $(0.05$ to 0.08 mmoles/1) than the pore-water samples and than essentially all other waters reviewed in this report; this trend did not occur with the surface samples of Henne (1982). The total carbonate content and $\mathrm{pH}$ of the surface waters did not differ from other tuffaceous waters.

\section{CONTROLS ON GROUNDWATER COMPOSITION}

In the previous section, relations were presented among many of the compositional variables of water from Yucca Mountain, NTS, and vicinity. These relations were primarily presented in the form of plots of one variable as a function of another. Very little effort was made in the previous section to connect the various relations observed with each other or with physical or chemical processes. This section describes a number of processes that appear to control water composition at Yucca Mountain and vicinity and relates these processes to the variations among compositional variables described $i$ the previous section.

\section{A. Control of Cation Content, Aqueous Silica Content, and $\mathrm{pH}$ of Tuffaceous}

\section{Water}

The primary cations in tuffaceous water at Yucca Mountain and vicinity are sodium, calcium, potassium, and magnesium. A number of studies in nearby 
(a) Rainier Meso Pore Water

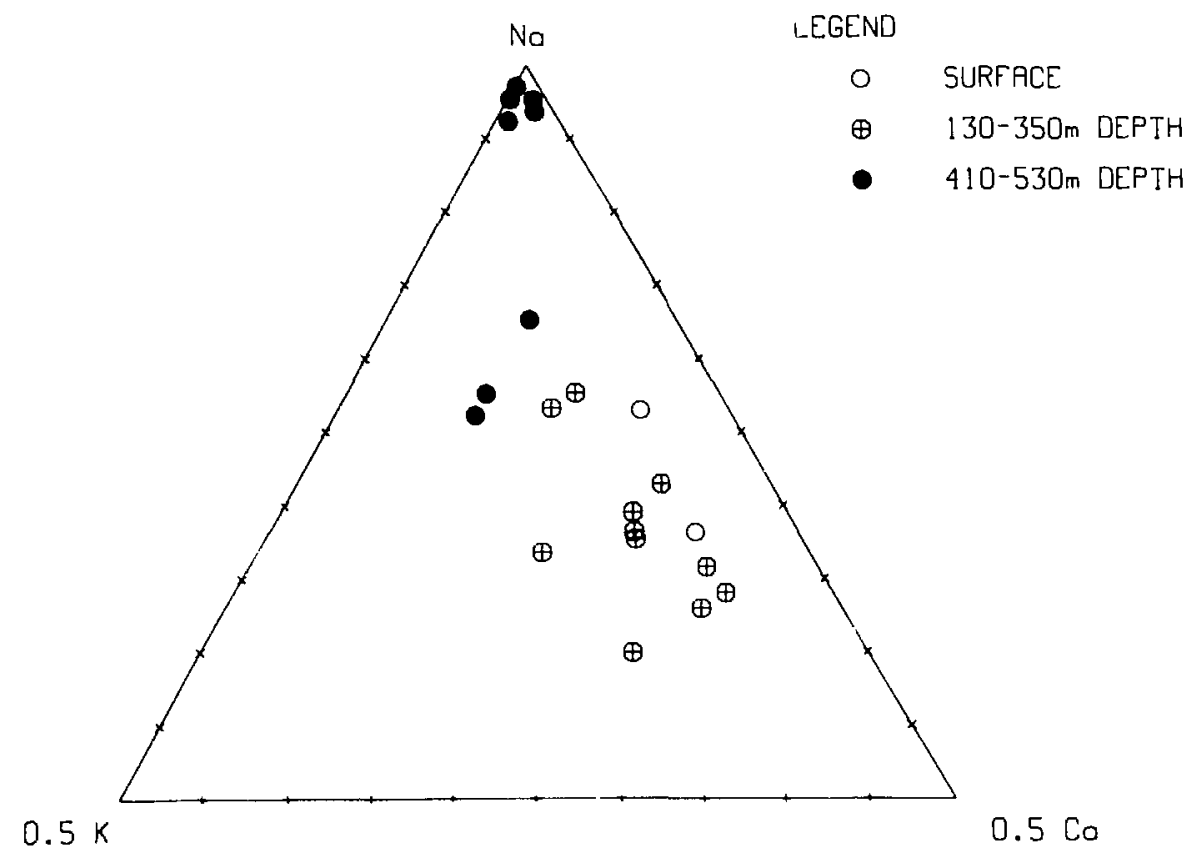

(b) Roinier Meso Fracture Water

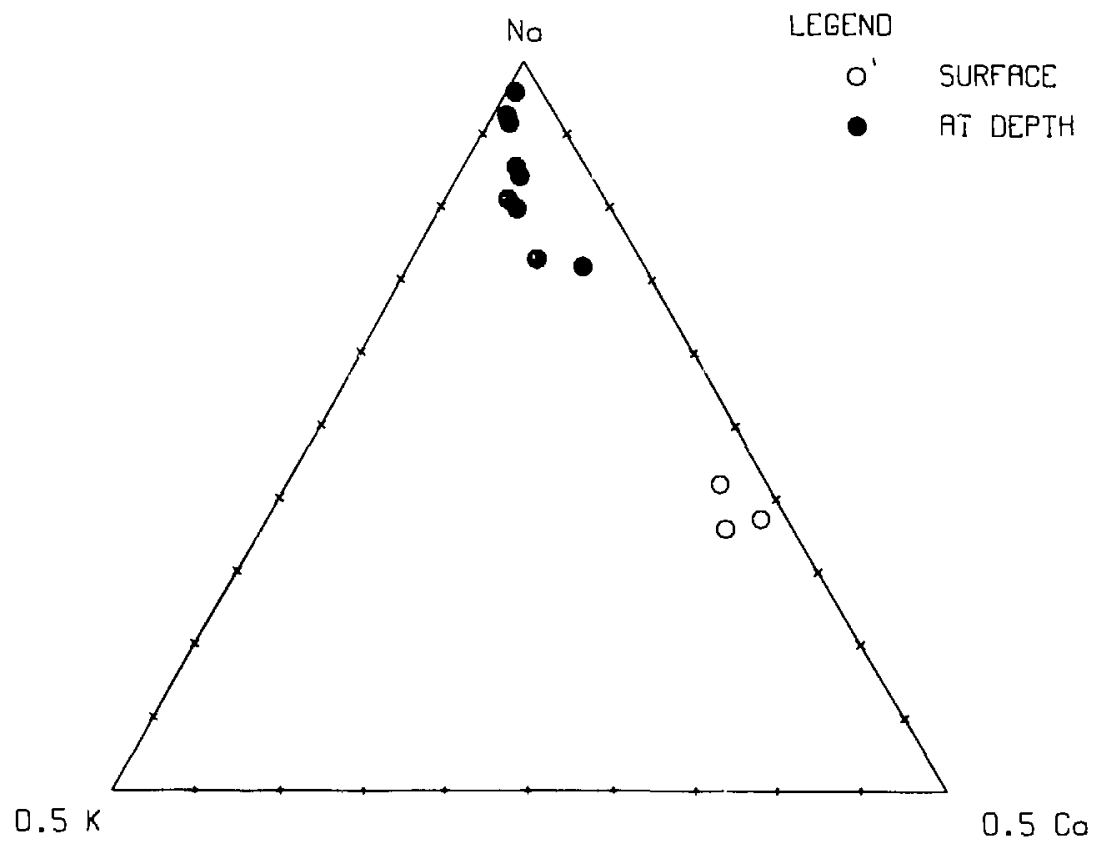

Fig. 25. Ternary diagrams of relative codium, calcium, and potassium content at Rainier Mesa.

a. Surface water and pore water (Benson 1976).

b. Surface water and fracture water (Henne 1982). 
and similar systems have led to the general conclusion that glass and mineral Jissolution, accompanied by secondary mineral precipitation, provides the primary control on cation composition of tuffaceous water (Hoover 1968; Winograd and Thordarson 1975; Claassen and White 1979; White et al. 1980; Moncure et al. 1981; Kerrisk 1983; Claassen 1985). The dissolution process represents an exchange of $\mathrm{H}^{+}$from the water for cations in the solid, as well as a breakup of the silicate structure of the solid. The reaction-path calculati: : s reported by Kerrisk (1983) indicate that early in the dissolution process, dissolution rates control the relative concentrations of sodium, calcium, potassium, and magnesium. As dissoluticn proceeds, calcium, potassium, and magnesium are incorporated into various secondary mineral precipitates such as zeolites and clays, thus decreasing their concentrations. The presence of these secondary minerals at Yucca Mountain (Bish and Vaniman 1985; Broxton et al. 1986) gives additional evidence that this process has been active. The net result of the dissolition and precipitation processes is an increase in relative sodium content $(\mathrm{Na} /(\mathrm{Na}+\mathrm{Ca}+\mathrm{K})$ ) of the water as well as an increase in $\mathrm{pH}$. The variation of $\mathrm{pH}$ with relative sodium content of water from Yucca Mountain and vicinity (see Fig. 5) is consistent with this process. Concentrations of calcium may also be limited by calcite solubility in the high-pH water in the western part of Yucca Mountain (see Fig. 10) and may be influenced by other supplies of calcium in the eastern part (see below). Water-composition data show that aqueous silica concentrations are near saturation with respect to cristobalite. Reaction-path calculations indicate that these high aqueous-silica activities are necessary for the stability of the zeolites found at Yucca Mountain (Kerrisk 1983).

Surface samples of water taken at Rainier Mesa demonstrate that this dissolution process starts at the surface. However, the tendency of the surface waters to have higher relative calcium contents $(\mathrm{Ca} /(\mathrm{Na}+\mathrm{Ca}+\mathrm{K}))$ and lower aqueous silica contents than water at depth (see Figs. 25) suggests that this process is continuing as water moves down through the unsaturated zone. The moderate cation concentrations of water from the saturated zone of the tuffaceous aquifer at Yucca Mountain (see Figs. 2 and 3 ) indicate that evaporation is not an important process for controlling concentrations. Ogard and Kerrisk (1984) have proposed that the $\mathrm{pH}$ of water in the tuffaceous 
aquifer at Yucca Mountain is buffered by aqueous carbonate and the minerals present.

There is an east to west variation in $\mathrm{Na} /(\mathrm{Na}+\mathrm{Ca}+\mathrm{K})$ of tuffaceous-aquifer water at Yucca Mountain (see Fig. 22) that is primarily raused by higher calcium content waters in the east than in the west. There is an opposite trend in total carbonate content; it is higher in the southwest than in the east (see Fig. 24). These two trends combine to result in water in the eastern part of Yucca Mountain (for example, Wells J-12, J-13, UE-25b\#1, UE-25c\#1, UE-25c\#2, and UE-25c\#3) with higher calcium and lower carbonate contents than water in the west (for example, USW $H-3$ and $H-6$ ). The variation in calcium content of Yucca Mountain water coincides with the east-west variation in calcium content of zeolites at Yucca Mountain described by Broxton et al. (1986). They state that the variation in calcium content of zeolites probably developed during initial stages of zeolite formation ( 11 to 14 million years ago) and that the enrichment of calcium in the eastern zeolites may have been caused by water from the carbonate aquifer mixing with tuffaceous water in that area. Based on a discussion of the carbonate content of water from Yucca Mountain (see section VII(B) below), mixing of tuffaceousand carbonate-aquifer waters does not appear to be occurring in water recently sampled. Thus, carbonate aquifer water is not causing the higher calcium content of tuffaceous-aquifer water presentiy found in the eastern part of Yucca Mountain. However, the eastern zeolites provide a source of calcium and that source is independent of carbonate; thus, it i's possible to have the eastern water higher in calcium but lower in total carbonate than water in the west if calcium is supplied to water presently in the eastern part of Yucca Mountain by cation exchange with the high calcium content zeolites. This mechanism provides an example of mineral compositions established in the past that influence present-day water compositions.

B. Control of Carbonate Content of Tuffaceous Water

Carbonate in water in the tuffaceous aquifer is normally considered to come from soil-zone carbon dioxide (Claassen 1985; White and Chuma 1986). This hypothesis is generally consistent with calculated carbon-dioxide pressures of tuffaceous water from Yucca Mountain and vicinity (see Fig. $8(\mathrm{~b})$ ), and with measured carbon-dioxide pressures in the gas phase of the unsaturated zone at Yucca Mountain (Yang et al. 1985). There is, however, a range of carbonate contents in the tuffaceous waters at Yucca Mountain $(1.8$ 
to $4.5 \mathrm{mmoles} / 1$ ) that is larger than one might expect if passage through the soll zone early in the recharge cycle is the only source. There are also relations between carbonate content and a number of other compositional variables that point toward a more complex plcture (see figs. $2(b), 3(b), 7$, 9, 12(a), 14(b), 15(b), 18(b), 19(b), 20(b), and 21(b)). In particular, tuffaceous-aquifer waters with higher carbonate contents tend to have higher pH (Fig. 7), lower carbon-dioxide pressures because of the shift in carbonate equilibria with pH (Fig. 9), and lower calcium contents (Fig. 3(b)). There are two sources of carbonate avallable to these waters: carbon dioxide (from the atmosphere, soli zone, or unsaturated-zone gas phase) and the carbonate aquifer. Some of the aqueous carbonate undoubtedly comes from carbon dioxide In the atmosphere and the soll zone as precipitation is recharged into the groundwater system. The relations between carbonate content and other compositional variables point to carbon dioxide as a more likely source of the additional carbonate in some waters at Yucca Mountain for three reasons. First, as pH increases, the equilibrium carbon-dioxide pressure drops, creating a driving force for dissolution of carbon dioxide from the gas phase. Second, carbonate in water from the carbonate aquifer would bring along calctum, which is quite low in concentration in the higher carbonate waters and in minerals in the western part of Yucca Mountain (Broxton et al. 1986), where the higher-carbonate waters are generally located. Third, it is unlikely that mixing low-pH water from the carbonate aquifer (UE-25p\#1 carbonate water) with dilute, intermediate-pH water from the tuffaceous aquifer is the cause of high-pH water in the tuffaceous aquifer. The conclusion that gaseous carbon dloxide is the source of additional aqueous carbonate at Yucca Mountain wells does not necessarily extend to other waters examined in this report. In particular, there are tuffaceous-aquifer wells at Pahute Mesa (UE-19c and UE-19d) with high total carbonate, intermediate pH, and moderate to high calcium content that could result from mixing of tuffaceous and carbonate waters.

The reasoning of the previous paragraph relates an increase in carbonate content to an increase in $\mathrm{pH}$ of the water. As discussed above in Section VII(A), and indicated in Fig. 5, the higher $\mathrm{pH}$ waters from the tuffaceous aquifer at Yucca Mountain tend to have higher relative sodium content $(\mathrm{Na} /(\mathrm{Na}+\mathrm{Ca}+\mathrm{K}))$, consistent with the process of glass and mineral dissolution and precipitation of secondary minerals as the cause (Claassen 1985; Kerrisk 
1983). This combination of glass and mineral dissolution, increasing water pH, and carbon-dioxide dissolution can be considered as mineral dissolution in a system that is open with respect to carbon dioxide. Mass transfer probably limits carbon-dioxide contents of deeper parts of the saturated zone, so that the entire saturated zone may only be partially open with respect to carbon dioxide. This may be the reason that calculated carbon-dioxide pressures of saturated zone water do not approach a limit with increasing $\mathrm{pH}$ (see Fig. $8(b))$. Claassen (1985) mentions that mineral dissolution in a system that is open with respect to carbon dioxide is a likely process in surface or shallow saturated-zone conditions. However, at Yucca Mountain, most of the tuffaceous-aquifer wells have deep unsaturated zones ( 300 to $700 \mathrm{~m}$ ). Although gaseous carbon dioxide has been observed in the deep unsaturated zone at Yucca Mountain (Yang et al. 1985), it is surprising that it could act as a source of aqueous carbonate.

Some additional information about this process can be obtained from the isotopic carbon data of Yucca Mountain waters (see Figs. 14(b) and 15(b)). In the Section VI(B) discussion of the variation of both ${ }^{14} \mathrm{C}$ (measured as percentage modern carbon, $\mathrm{PMC}$ ) and ${ }^{13} \mathrm{C}$ (measured as $\delta^{13} \mathrm{C}$ ) contents of Yucca Mountain water with total carbonate content, the possibility was mentioned that the observed variation could result from mixing tuffaceous and carbonate waters. This process was proposed because of the continuity of the tuffaceous and carbonate data seen in Figs, 14(b) and 15(b). However, based on the mode 1 described above of glass and mineral dissolution in a system open or partially open to carbon dioxide, mixing of carbonate and tuffaceous waters is not considered likely at Yucca Mountain. In an attempt to see if the model of carbon-dioxide addition to saturated-zone water could explain the variation of PMC and $\delta^{13} \mathrm{C}$ with total carbonate content, a simplified carbon-balance model was developed. The model is based on the assumption that an initial charge of carbonate (probably from the soil zone) is present in the water and that carbonate from another source (carbon dioxide in the gas phase of the unsaturated zone) is added at some rate as time progresses. The rate of change of the isotope $\left({ }^{14} \mathrm{C}\right.$ or $\left.{ }^{13} \mathrm{C}\right)$ content of the water is the sum of three components. (1) addition with the added carbonate, (2) addition or loss by isotopic exchange between the water and the carbon-dioxide source, and (3) loss by radioactive decay (for ${ }^{14} \mathrm{C}$ only). If $x$ is the isotope concentration 
(PMC for ${ }^{14} \mathrm{C}$, or $\delta^{13} \mathrm{C}$ for ${ }^{13} \mathrm{C}$ ) in the water and $\mathrm{C}$ is the total carbonate content of the water at time $t$. then

$$
d(x C) / d t=x_{s}(d C i d t)-\gamma\left(x-x_{s}\right)-\lambda x C,
$$

where $x_{s}$ is the isotope concentration of the carbon-dioxide source cassumed constant), $\lambda$ is the radioactive decay constant $\left(\lambda=1.24 \times 10^{-4} / \mathrm{yr}\right.$ for ${ }^{14} \mathrm{C}$ and 0 for ${ }^{13} \mathrm{C}$ ), and $\gamma$ is a constant relating the rate of isotopic exchange to the concentration difference between the water and the carbon-dioxide source. By expanding the derivative on the left, Eq. (2) can be rewritten as

$$
d x / d t=-(1 / C)[y+(d C / d t)]\left(x-x_{s}\right)-\lambda x
$$

In Eqs. (2) and (3), the quantity (dC/dt) represents the addition rate of carbonate to the water, and $C$ is related to $t$ by

$$
C=C_{0}+\int_{0}^{t}(d C / d \tau) d \tau
$$

where $C_{0}$ is the initial carbonate content of the water $(t=0)$. Equation (3) is a linear, first-order differential equation with nonconstant coefficients. An initial condition, specifying the initial isotope concentration $\left(x=x_{0}\right.$ at $t=0$ ), is required in addition to the initial condition on total carbonate content.

The rate of addition of carbonate to the water that is needed to solve Eq. (3) should be a function of the difference between the gas-phase carbon-dioxide pressure and the equilibrium carbon-dioxide pressure over the water. No attempt was made to model this aspect of the process; instead. isotope concentrations calculated using a variety of different carbonate addition rates were compared with the observed variation of PMC or $\delta^{13} \mathrm{C}$ with carbonate content. Even for the simplest case considered, dC/dt constant, a closed form solution to Eq. (3) was not found; the results discussed here were obtained from a numerical solution. Initial attempts to use a constant carbonate addition rate gave poor agreement between calculated and observed PMC values at Yucca Mountain; the calculated results did not drop as steeply as the observations at low carbonate content (see Fig. $14(b)$ ). It was found 
that a carbonate addition rate that increased with time gave much better results. For calculational purposes, a carbonate addition rate of

$$
d C / d t=\alpha e^{(\beta t)}
$$

was used, where $\alpha$ and $\beta$ are positive constants. With this form, Eq (4) gives

$$
C=C_{0}+(\alpha / \beta)\left[e^{(\beta t)}-1\right]
$$

For the ${ }^{14} \mathrm{C}$ data, reasonable comparisons between calculated and observed PMC values could be obtained with $(y>0)$ or without $(y=0)$ isotopic exchange. However, for the ${ }^{13} \mathrm{C}$ data, calculated results without isotopic exchange did not compare well with all the observations. Figures 26 and 27 show plots of PMC and $\delta^{13} C$ as a function of total carionate for water from Yucca Mountain and vicinity; the data points plotted are the same as those in Figs. 14(b) and 15(b) and the lines represent calculated results from this model. Table IV lists the values of the parameters used to obtain the calculated results in these figures. The same definition of the carbonate addition rate (values of $\alpha$ and $B$ ) and initial carbonate content $\left(C_{0}\right)$ were used for all the calculations. The model fits the shape of the PMC variation with carbonate content (Fig. 26) reasonably well. Acceptable values for $x_{s}$ (the PMC value of the carbon dioxide in the gas phase of the unsaturated zone) decrease from about $75 \%$ to about $40 \%$ as isotopic exchange increases ( $y$ increases). Yang et a). (1985) observed values of PMC of 60 to $80 \%$ for carbon dioxide in the gas phase of the unsaturated zone at $20-$ to $150-m$ depth in Yucca Mountain. Above 20-m depth the effects of modern ${ }^{14} \mathrm{C}$ were seen (PMC > 100\%), and below $150-\mathrm{m}$ depth there was more scatter, the data ranging from 50 to $100 \%$ PMC. Attempts to use very low values of $x_{s}$ (such as might result from the carbonate aquifer being the source of carbon) did not produce a good comparison between the model and the data.

The relation between the model and the variation of $\delta^{13} \mathrm{C}$ of Yucca Mountain water with carbonate content is not as clear (see Fig. 27). A group of wells with $\delta^{13} \mathrm{C}$ of about $-7 \%$ ( $\mathrm{J}-13$, UE-25C\#1, UE-25C\#2, USW $4-4$, and $\left.H-6\right)$ span a range of carbonate contents from about 2 to 4 mmoles $/ 1$. A constant $\delta^{13} \mathrm{C}$ with increasing carbonate content could be accommodated by the model if $x_{0}=x_{5}=$ $-7 \%$ (a value of $x_{5}$ of $-7 \%$. would correspond to $\delta^{13} \mathrm{C}$ of about -14 to 


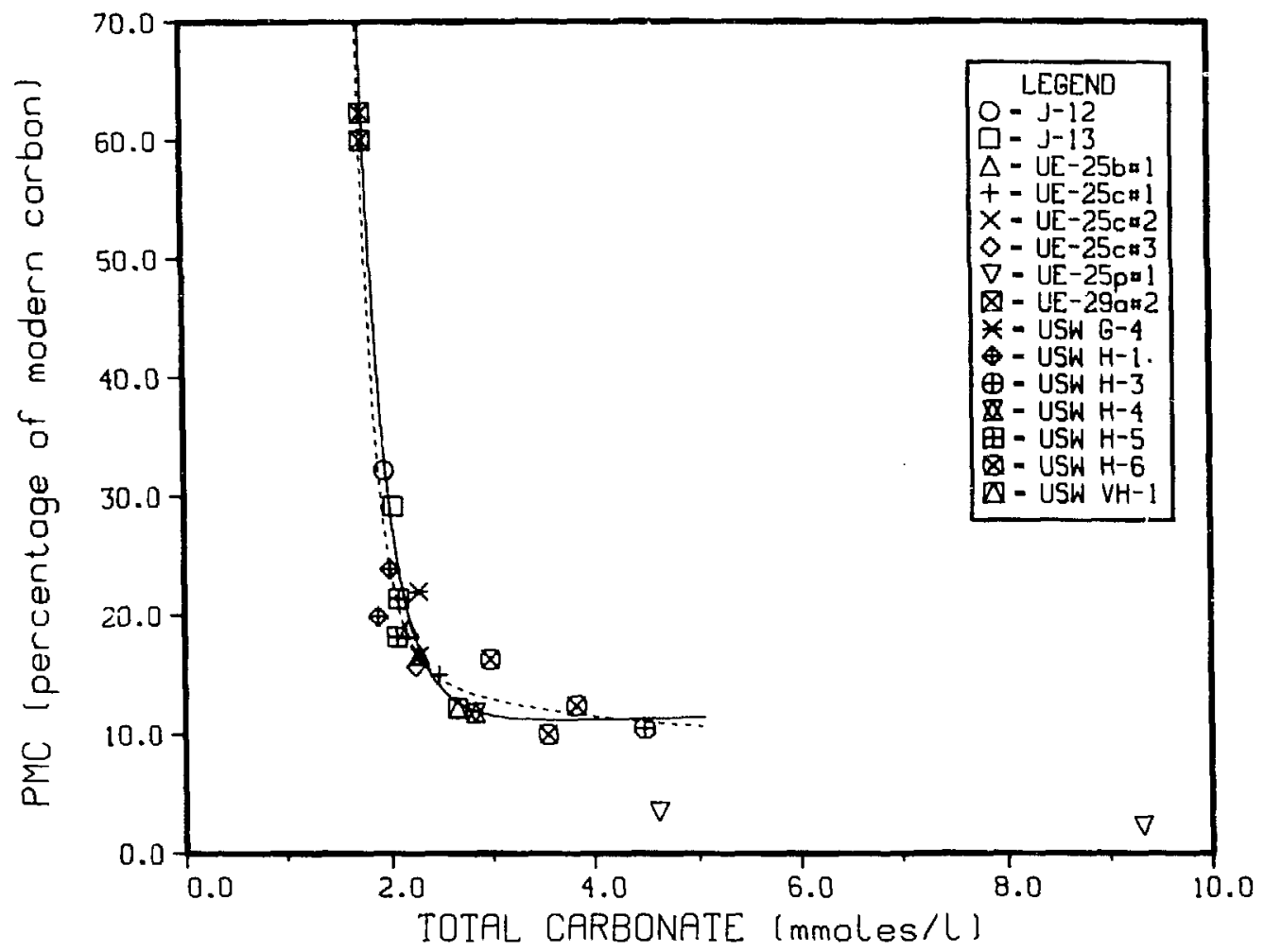

Fig. 26. Percentage of modern carbon as a function of total carbonate content at Yucca Mountain with carbon-model prediction (see Table IV for solid and dashed curve definitions).

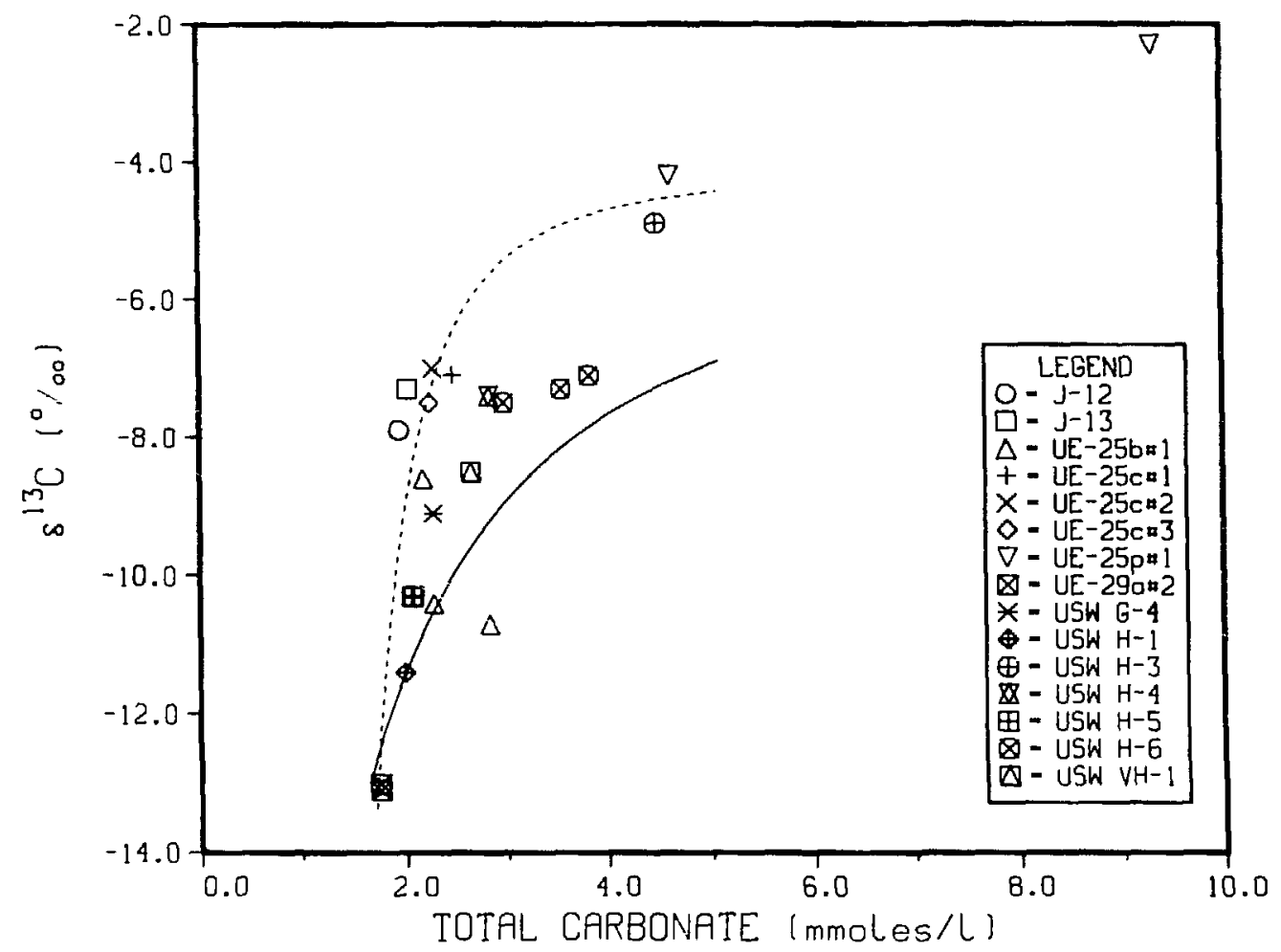

Fig. 27. ${ }^{13} \mathrm{C}$ as a function of total carbonate content at Yucca Mountain with carbon-model prediction (see Table IV for solid and dashed curve definitions). 
CARBON MODEL PARAMETERS USED IN FIGURES 26 AND 27

\begin{tabular}{llllll} 
& \multicolumn{3}{c}{ Figure 26} & \multicolumn{2}{c}{ Figure 27 } \\
\cline { 2 - 3 } Constant & Solid Curve & Dashed Curve & & Solid Curve & Dashed Curve \\
$C_{0}$ (mmoles/1) & 1.65 & 1.65 & 1.65 & 1.65 \\
$\alpha$ (mmoles/1.yr) & $3.0 \times 10^{-5}$ & $3.0 \times 10^{-5}$ & $3.0 \times 10^{-5}$ & $3.0 \times 10^{-5}$ \\
$3(1 / y r)$ & $2.5 \times 10^{-5}$ & $2.5 \times 10^{-5}$ & $2.5 \times 10^{-5}$ & $2.5 \times 10^{-5}$ \\
$\gamma($ mmoles/1.yr) & 0.0 & $1.0 \times 10^{-4}$ & 0.0 & $1.0 \times 10^{-4}$ \\
$\lambda(1 / y r)$ & $1.24 \times 10^{-4}$ & $1.24 \times 10-4$ & 0.0 & 0.0 \\
$x_{5}$ & $75.0 \%$ & $40.0 \%$ & $-4.0 \%$ & $-4.0 \%$ \\
$x_{0}$ & $100.0 \%$ & $100.0 \%$ & $-13.0 \%$ & $-15.0 \%$
\end{tabular}

$-15 \%$ for the carbon dioxide in the gas phase because of fractionation between the aqueous ( $\mathrm{pH} 7$ to 8) and gas phases). However, data from other wells are not consistent with this assumption. The curves in Fig. 27 show how $\delta^{13} \mathrm{C}$ of the water would vary from a relatively negative value as carbonate with $\delta^{13} \mathrm{C}=-4^{\circ} \%$ (corresponding to carbon dicxide with $\delta^{13} \mathrm{C}$ of about -11 to $-12 \%$ ) is added. Without isotopic exchange, the model does not fit the data well; the inclusion of isotopic exchange is needed to get a steep rise in $\delta^{13} \mathrm{C}$ at low carbonate contents. Yang et al. (1985) observed $\delta^{13} \mathrm{C}$ values for carbon dioxide in the gas phase of the unsaturated zone at Yucca Mountain of -10 to $-18 \%$ below about $60-m$ depth. The choice of $x_{s}$ for ${ }^{13} \mathrm{C}$ is consistent with these observations.

This choice of parameters in Fig. 26 (pirticularly $\alpha$ and $B$ ) results in a time of approximaiely $49,000 \mathrm{yr}$ to achieve 4.5 mmoles/l total carbonate content and 11\% PMC, which are characteristic of USW H-3. The apparent age of H-3 water based on the measured PMC of $10.5 \%$ is $18,100 \mathrm{yr}$. The model requires $10,000 \mathrm{yr}$ to achieve 2.0 mmoles/1 total carbonate and $30 \%$ PMC, which are characteristic of J-13; the apparent age of J-13 water based on the measured PMC of $29.2 \%$ is $9,900 \mathrm{yr}$. The net result of this model is that for water with less than about 2 mmoles/l total carbonate, the age of the water is essentially the apparent age. However, as the carbonate content rises above 2 
mmoles/1, the apparent age underestimates the true age. The continual addition of younger carbon to the water means that as the carbonate content increases, larger corrections are required to the apparent age. This situation contrasts with what would exist if the variation of PMC with carbonate content was caused by the addition of carbonate water or old carbon dioxide ( $P M C=\sim 0 \%$ ) to the tuffaceous water; the apparent age of the mixture would then overestimate the true age.

The variation of $S D$ with PMC and total carbonate content of water from Yucca Mountain and vicinity was shown in Figs. 18. Claassen (1985) interpreted a similar variation of $\delta D$ with apparent age for water from the Amargosa Desert and Fortymile Wash to indicate that older water (apparent age, about 15,000 yr) precipitated under colder conditions (see Section VI(B)). The carbonate model proposed here predicts that the true ages of water with higher carbonate contents would be older than their apparent ages. Figure $28(a)$ shows a plot of $\delta D$ as a function of apparent age for water from Yucca Mountain and vicinity. This plot uses the data plotted in Fig. 18(a) with apparent age calculated from Eq. (1); the data from UE-25p\#1 were not included because carbonate derived from Paleozoic carbon would require corrections to be comparable to carbonate in tuffaceous waters. Figure $28(b)$ shows the same data plotted as a function of the carbon-model age, where the carbon-model age was calculated from the total carbonate content using Eq. (5) and the values of $\alpha$ and $B$ shown in Table IV. In Fig. 28(a), the data bunch up in the 15,000to 20,000-yr apparent age range; in Fig. 28(b), this range of apparent ages is spread out over 20,000- to 50,000-yr carbon-model age. Assuming the relation of $\delta D$ with precipitation temperature, the application of the carbon mode 1 to the Yucca Mountain carbonate data indicates that colder temperatures (lower values of $\delta D$ ) existed 20,000 to $50,000 \mathrm{yr}$ ago. Spaulding (1985) estimated that colder average-annual temperatures existed in the vicinity of NTS from 18,000 to $38,000 \mathrm{yr}$ ago, with somewhat warmer temperatures (still below modern temperatures) from 38,000 to $45,000 \mathrm{yr}$ ago. Thus, the carbon model proposed here is generally consistent with those estimates.

The results of applying the carbon model to Yucca Mountain data should probably not be interpreted quantitatively. The parameters in Table IV were chosen to show that the model was generally consistent with the variation of PMC and $\delta^{13} \mathrm{C}$ with total carbonate content and with the proposal that colder 

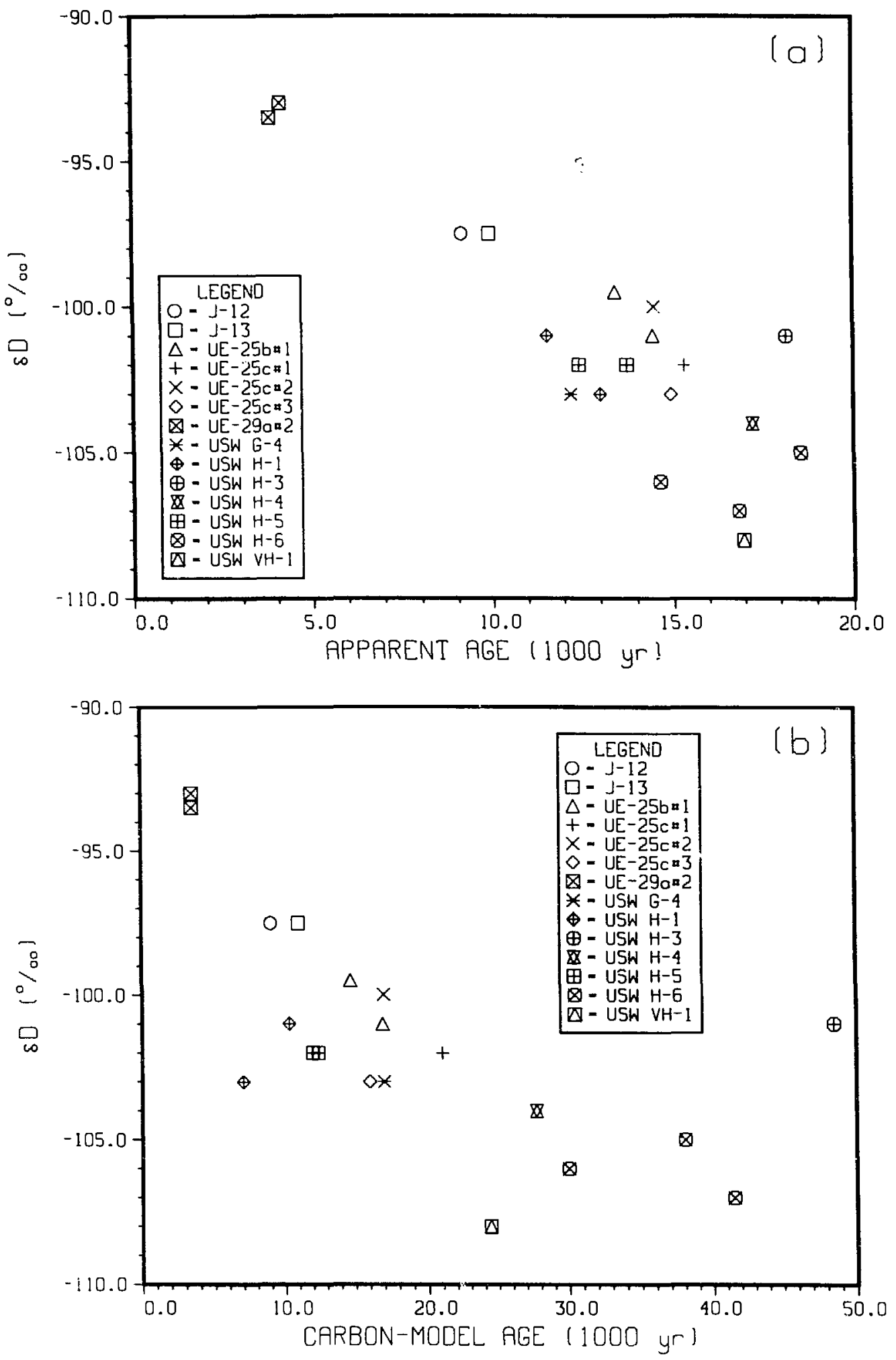

Fig. 28. $\delta D$ as a function of apparent age and carbon-model age at Yucca Mountain.

a. $\delta D$ as a function of apparent age.

b. $\delta D$ as a function of carbon-model age. 
temperatures were the cause of the variation of $\delta D$ with PMC. Even though the carbon-model ages may not be quantitatively accurate, the concept that water with higher total carbonate contents (for example, USW $H-3, H-4$, and $H-5$ ) may be older than the apparent age of the water is quite plausible. Classen (1985) observed that groundwaters with apparent ages older than about 17,000 yr were not present in the tuffaceous aquifers of the Amargosa Desert area he studied. Apparent ages of water from the tuffaceous aquifer at Yucca Mountain are also less than about 20,000 yr (see Fig. 28(a)). Claassen's preferred explanation for this observation was that snowfall earlier than about 20,000 yr ago was insufficient to result in recharge (Claassen 1985; Spaulding 1985). The discussion of aqueous carbonate in water from the tuffaceous aquifer at Yucca Mountain and vicinity that was presented here provides an alternate explanation for this observation That explanation is that the apparent age of Yucca Mountain water with more than about 2 mmoles/l total carbonate tends to underestimate the true age. Thus, the model predicts that water older than 20,000 yr is present at Yucca Mountain, but corrections are required to the apparent age.

c. Control of Chloride and Sulfate Content of Tuffaceous Water

Precipitation is usually considered a primary source of chloride and sulfate in the water around Yucca Mountain. NTS, and vicinity. Under some conditions both chloride and sulfate are considered as conservative species, that is, having no sources or sinks in the groundwater system (Claassen 1985). In other situations, a source of sulfate has been proposed for some waters. Winograd and Thordarson (1975) proposed dissolution of gypsum in the basal strata of Tertiary rocks as a source for the lower carbonate aquifer and some particular wells. White (1979) proposed a hydrothermal source of sulfate in Oasis Vailey. Young (1972) also proposed hydrothermal alteration as the source of high sulfate concentrations in water from one well in eastern Jackass Flats, near the Calico Hills. Most of the tuffaceous waters at Yucca Mountain and vicinity discussed in Section VI(A) have low chloride $(0.16$ to 0.31 mmoles/l) and sulfate $(0.17$ to 0.32 mmoles/l) concentrations (see Figs 11,12 , and 13). One well near Yucca Mountain, USW VH-1 in Crater Flat, has somewhat higher sulfate content $(0.45$ mmoles/1) than the other tuffaceous waters and may indicate a minor, local source of sulfate in crater fiat. Compared to other areas such as Oasis valley, evaporation does not appear to be important in the saturated zone of the tuffaceous aquifer at Yucca Mountain. 
Both chlorine and sulfur are present in rocks at Yucca Mountain. Warren and Broxton (1986) have measured the chlorine content of a large number of core samples from NTS; an average chlorine content is about $500 \mathrm{ppm}$. They also observed that zeolitized tuff has little or no chlorine left. Vaniman (1986) has reported the sulfur content of Topopah Spring and Calico Hills tuff from drill hole USW G-4; values range from 46 to 137 ppm sulfur. Thus, the tuff may also represent a source of chloride and sulfate for water in the saturated zone. The sulfur/chlorine molar ratio of the tuff source is only about one-tenth the sulfate/chloride ratio in the water; for this reason, the tuff is probably only a minor source of these species at most.

Figure $12(a)$ showed an nearly linear relation between sulfate and total carbonate contents of water from Yucca Mountain and vicinity; chloride did not show a similar relation (see Fig. $12(\mathrm{~b})$ ). The carbon model described above (Section VII(B)) proposed gaseous carbon dioxide as the source of additional carbonate in this water. A source of sulfate added with the carbon dioxide does not seem likely. Other variables that may lead to this relationship are the higher pH and older age of water with added carbonate. A physical or chemical process that results in this relationship has not been identified at this time.

Based on the chloride and sulfate contents of saturated-zone water around Yucca Mountain, there seems no need of sources of these species other than precipitation. The difference between the average sulfate/chloride molar ratio of 0.82 for all the waters reviewed here (see Fig. 13(a)) and the ratio for modern precipitation of $\sim 1.65$ (Claassen 1985) may be that modern precipitation contains higher concentrations of sulfate and nitrate because of fossil fuel burning (Mayewski et al. 1986).

D. Control of the Redox State of the Water

Measurements of the redox state of water are available only for samples from Yucca Mountain and these data present a somewhat confusing picture. Most measurements indicate oxidizing conditions. However, measurements on some samples pumped from packed-off zones or taken from static wells show reducing conditions. This situation may be a sign of reducing conditions in deep saturated-zone water with oxidizing conditions near the static water level where interaction with oxygen in the unsaturated-zone gas phase is possible; vertical mixing during pumping may disturb this condition. 
There is little information available about what reactions might contribute to reducing conditions in the deep saturated zone. Ogard and Kerrisk (1984) proposed that reducing conditions in the water were produced by reactions with organic matter as the water recharged through the soil zone. They further proposed that conditions in the past were suitable for these reactions to occur, but present conditions are not. Caporuscio and Vaniman (1985) have reported that iron is present in reduced form in rocks at Yucca Mountain, but that it appears to be generally inaccessible to the water. Thus, the iron is probably not a factor in controlling the redox state of the water.

It would be difficult to prove with the present data base that reducing conditions exist in deep saturated-zone water at Yucca Mountain. Regardless of the state of the deep saturated zone, water at the static water level appears to be oxidizing. Pore water or fracture water in the unsaturated zone will probably also be oxidizing. Thus, oxidizing conditions will be present in water over a significant portion of the transport path of radionuclides from the repository.

E. Control of Other Compositional Variables of Tuffaceous Water

Three other compositional variables discussed in Section VI(C) showed relations that may indicate controls on these variables. They are nitrate, fluoride, and water temperature.

The nitrate content of water from Yucca Mountain and vicinity decreases with decreasing PMC (increasing age) as seen in Fig. 19(a). The soil zone or precipitation are the most likely sources of nitrate in water recharged to the saturated zone. There are no aqueous-solid reactions that would provide a sink for nitrate in these waters. However, the reduction of nitrate in the saturated zone represents a possible sink. Some evidence for reducing conditions in water below the static water level at Yucca Mountain and for the variation of nitrate content with redox conditions in Well UE-25b\#1 was given in Section VI(A). Although no proof is available, reduction of nitrate represents a plausible mechanism for decreasing nitrate content with age.

Figures 20 showed a tendency for fluoride content to increase with increasing sodium and carbonate content of water from Yucca Mountain and vicinity (see Section $V I(C)$ ). The fluoride content of these waters also showed a consistent variation with location similar to the total carbonate variation represented in Fig. 24 (see Section VI(D)). The $\log _{10}(Q / K)$ for 
fluorite ranged from -1.9 (undersaturated) to 0.04 (just above saturation) for water from the tuffaceous aquifer; most waters had $\log _{10}(Q / K)$ of -0.6 or less. Fluorite has occasionally been observed in fractures at Yucca Mountain (Bish and Vaniman 1985), but not to the extent that it would represent a general mineralogical control on fluoride concentrations. A few analyses of the fluorine content of glass from NTS have been done; results range from 0 to 0.26 wt\% fluorine with an average of $0.19 w t \%$ (Warren and Broxton 1986). Compared with the $500 \mathrm{ppm}$ chlorine content discussed above (Section VII(C)), there is considerably more fluorine than chlorine in the tuff (the fluorine/chlorine molar ratio is about 7 ). Thus, the tuff may act as a source of fluoride for the water. The increase of fluoride with increasing sodium and carbonate contents as well as $\mathrm{Na} /(\mathrm{Na}+\mathrm{Ca}+\mathrm{K})$ may be an indication that as glass dissolution and mineral precipitation reactions proceed, fluorine is also released to the water.

The temperature of water from Yucca Mountain and vicinity tended to increase with decreasing PMC (increasing age) and with increasing total carbonate content (see Figs. 21). The temperature of Well USW H-3 water did not fit this relationship. There appears to be some relation other than just depth that influences water temperature; however, it has not been identified at this time.

F. Controls on Unsaturated-Zone Water Composition

The only date on unsaturated-zone water compositions come from the work of Benson (1976) at Rainier Mesa. This water showed one unusual compositional feature, the chloride and sulfate contents were high relative to the total carbonate content (see figs. 11). This led to lower calculated carbon-dioxide equilibrium pressures than most other waters in the same pH range (see fig. $8(a))$. The major cation composition was similar to other waters reviewed (see Fig. $4(a))$. There were no ${ }^{14} \mathrm{C},{ }^{13} \mathrm{C},{ }^{18} 0$, or deuterium contents available for these water samples; this limits the possible comparisons that can be made. The composition of the gas phase of the unsaturated zone at Yucca Mountain has also been measured. The overall chemical composition is similar to air (Yang 1986). Below the soll zone (top 20 to $30 \mathrm{~m}$ ), carbon-dioxide pressures of $\sim 10^{-3} \mathrm{~atm}$ or less were measured (Yang et al. 1985).

For this discussion, the primary difference between processes that are important in the unsaturated and saturated zones is the presence of the gas phase in the unsaturated zone. Pore water in the unsaturated zone can react 
with the rock or the gas-phase constituents and should present a relatively large surface area to both phases. The presence of the gas phase allows evaporation to occur more readily in the unsaturated zone, and the large gas-aqueous surface area means higher mass-transfer rates and closer approach to gas-aqueous equilibrium. Evaporation of pore water could be the mechanism for increasing chloride and sulfate concentrations. Also, carbon-dioxide equilibrium pressures in pore water should be closer to the gas phase carbon-dioxide pressure. The calculated carbon-dioxide equilibrium pressures of Rainier Mesa pore water (see Fig. $8(a)$ ) are consistent with the carbon-dioxide pressures observed in the gas phase at Yucca Mountain. The pH of Rainier Mesa pore water is generally in the 7 to 8 range. The calcium content of this water is higher than most of the tuffaceous waters at Yucca Mountain, but consistent with other tuffaceous water such as in the Amargosa Desert (see Fig. $4(a)$ ). The aqueous silica content is also similar to other tuffaceous waters. Thus, the pore water is probably undergoing the same glass and mineral dissolution and precipitation reactions as saturated-zone water in the tuffaceous aquifer. The extent of these reactions may be influenced by increased concentrations from evaporation.

The trends in unsaturated-zone compositions seen at Rainier Mesa may be the result of glass and mineral dissolution and precipitation reactions that are similar to those discussed for the saturated zone, accompanied by evaporation in a system that is open with respect to carbon dioxide. At present, this hypothesis is rather speculative. More compositional data, in particular some isotopic data, are needed to establish what processes control unsaturated-zone water compositions.

\section{IMPLICATIONS FOR RADIONUCLIDE TRANSPORT}

One of the primary reasons for studying water chemistry at Yucca Mountain and vicinity is to provide information for calculations of radionuclide transport. Water chemistry can influence waste-element solubility, speciation, and sorption, and through these processes, the rates at which waste elements are transported away from the repository. Water chemistry can also affect the stability and composition of minerals. This section discusses some implications of the water chemistry for solubility, speciation, and mineral stabllity. 
The relative concentrations of major cations (sodium, calcium, and potassium) in water from the tuffaceous aquifer at Yucca Mountain and vicinity vary over a range of relative sodium and calcium contents at nearly constant relative potassium content (see Fig. $4(b)$ ), with higher relative sodium content in the west than in the east (see Fig. 22). Broxton et al. (1986) see related variations in the sodium and calcium contents of zeolites. Sorption of some waste elements on zeolites is by ion exchange, in which the waste-element cation replaces an existing cation (such as sodium, calcium, or potassium) in the zeolite. At this time, no variations in zeolite sorptive behavior (measured values of the sorption coefficient) have been related to variations in cation contents of the zeolites (Danlels et a1. 1982; Ogard and Vaniman 1985); a relation of this nature may be difficult to demonstrate because of the precision of the data. Solubilities of some waste elements may be affected to a minor extent by changes in cation content of the water if the solid controlling solubility contains one of the cations; an example of this is neptunium, where $\mathrm{Na}_{3} \mathrm{NpO}_{2}\left(\mathrm{CO}_{3}\right)_{2} \bullet \mathrm{nH}_{2} \mathrm{O}$ was identified as the solid that precipitated from neptunium solutions in Well J-13 water (Nitsche and Edelstein 1985). The range of major cation concentrations observed at Yucca Mountain and vicinity should not significantly affect solubility or sorption of waste elements; however, these effects are being examined by sorption and solubility experiments using various water compositions (Ogard and Vaniman 1985; Kerrisk 1985).

The process of glass and mineral dissolution in a system open or partially open with respect to carbon dioxide was proposed as an explanation for the variation in carbonate content of tuffaceous waters seen at Yucca Mountain. Based on this model, carbonate contents of saturated zone waters could vary depending on the extent of dissolution or age of the water. Because carbonate forms complexes and sollds with some important waste elements such as americium, uranium, and neptunium (Ogard and Kerrisk 1984; Nitsche and Edelstein 1985), this variation may have significant effects. Solubility and sorption experiments using water compositions that cover a range of carbonate concentrations are being done by the NNWSI Project (Ogard and Vaniman 1985; Kerrisk 1985).

The chloride and sulfate contents of saturated-zone tuffaceous waters from Yucca Mountain and vicinity are relatively low compared to most other waters in this area (see Fig. $11(b)$ ). Although chloride does not form strong 
complexes with waste elements, sulfate does form complexes and solids that may affect speciation, sorption, or solubility (Ogard and Kerrisk 1984).

Unsaturated-zone pore water from Rainier Mesa showed high chloride and sulfate content relative to the carbonate content of the water (see $F i g .11(a)$ ). If this condition also occurs at Yucca Mountain, the effects of varying sulfate content on solubility, sorption, or speciation may have to be investigated.

The fluoride content of water from Yucca Mountain and vicinity varies over a relatively wide range (see Figs. 20), but fluoride is still a minor anion. Some waste elements form complexes with fluoride cogard and Kerrisk 1984), so that solubility and sorption experiments should also give consideration to this variation. The nitrate content also varies over a relatively wide range (see Figs. 19). However, nitrate does not readily form complexes or solids, so that variations of the nitrate content are not important for solubility or sorption.

The $\mathrm{pH}$ of water from the tuffaceous aquifer at Yucca Mountain and vicinity falls in the range of 7 to 9.2 , with most samples in the 7 to 8 range. Both the carbonate content of the water and the local minerals buffer $\mathrm{pH}$ (Ogard and Kerrisk 1984). Variations in pH over this rarige can have a significant effect on solubility and speciation of some waste elements (Allard 1982; Apps et al. 1983). Solubility and sorption experiments using water compositions that cover a range of $\mathrm{pH}$ are being done by the NNWSI Project (Ogard and Vaniman 1985: Kerrisk 1985). Although there are some indications that water in deep regions of the saturated zone at Yucca Mountain may be reducing, this situation, which would lead to lower solubilities of many waste elements, could be difficult to prove. Water in the unsaturated zone and near the static water level is probably oxidizing. Solubility and sorption experiments in the NNWSI Project are being done under oxidizing conditions.

Except for a few samples of water taken near the ground surface, aqueous silica contents of water from Yucca Mountain, NTS, and vicinity are at or above cristobalite saturation. The relatively high aqueous silica content of these waters may affect solubilities of some waste elements (Mendel 1984). If waste-element silicates do control solubilities of any important waste elements under conditions at Yucca Mountain, this information will be obtained from the NNWSI solubility-experiments that are in progress (Kerrisk 1985). Kerrisk (1983) proposed that a high aqueous silica activity was needed for 
stability of the zeolites found at Yucca Mountain. The stability of zeolites is also being investigated by the NNWSI Project (Wolfsberg and Vaniman 1984).

\section{ACKNOWLEDGEMENTS}

The author would like to thank Katherine Campbell of Los Alamos National Laboratory for her help in setting up the SASO data base and discussing the variation of water composition with location. He would also like to thank Allen E. Ogard of Los Alamos National Laboratory and Art F. White of Lawrence Berkeley Laboratory for their helpful comments on an early draft of this report. 


\section{REFERENCES}

Allard, B., "Solubilities of Actinides in Neutral or Basic Solutions," in Actinides in Perspective, N. M. Edelstein (Ed.), Pergamon Press, New York, 1982.

Apps, J. A., C. L. Carnahan, P. C. Lichtner, M. C. Michel, D. Perry, R. J. Silva, 0 . Weres, and $A$. F. White, "Status of Geochemical Problems Relating to the Burial of High-Level Radioactive Waste, 1982," Lawrence Berkeley Laboratory report LBL-15103 (NUREG/CR-3062), (March 1983).

Benson, L. V., "Mass Transport in Vitric Tuffs of Rainier Mesa, Nye County, Nevada," Water Resources Center, Desert Research Institute report NVO-1253-10 (October 1976).

Benson, L. V. and P. W. MCKinley, "Chemical Composition of Ground Water in the Yucca Mountain Area, Nevada, 1971-84,"U. S. Geological Survey Open-File Report $85-484$ (1985).

Benson, L. V., J.H. Robison, R. K. Blankennagel, and A. E. Ogard, "Chemical Composition of Ground Water and the Location of Permeable Zones in the Yucca Mountain Area, Nevada," U. S. Geological Survey Open-File Report 83-854 (1983).

Bish, D. L. and D. T. Vaniman, "Mineralogic Summary of Yucca Mountain, Nevada," Los Alamos National Laboratory report LA-10543-MS (October 1985).

Blankennagel, R. K. and J.E. Weir, Jr. "Geohydrology of the eastern Part of Pahute Mesa, Nevada Test Site, Nye County. Nevada," U. S. Geologica? Survey Professional Paper 712-B (1973).

Broxton, D. E., D. L. Bish, and R. G. Warren, "Distribution and Chemistry of Diagenetic Minerals at Yucca Mountain, Nye County, Nevada," to be published in Clays and Clay Minerals (1986).

Caporuscio, F. A. and D. T. Vaniman, "Iron and Manganese in Oxide Minerals and in Glasses: Preliminary Conslderations of Eh Buffering Potential at Yucca Mountain, Nevada," Los Alamos National Laboratory report LA-10369-MS (April 1985).

Claassen, H. C., "Water Quality and Physical Characteristics of Nevada Test Site Water-Supply Wells," U. S. Geological Survey report USGS-474-158 (January 1973).

Claassen, H. C., "Sources and Mechanisms of Recharge for Ground Water in the West-Central Amargosa Desert, Nevada - A Geochemical Interpretation," U. S. Geological Survey Professional Paper 712-F (1985).

Claassen H. C. and A. F. White, "Application of Geochemical Kinetic Data to Groundwater Systems," in Chemical Modeling - Speciation, Sorption, Solubility, and Kinetics in Aqueous systems, E. A. Jenne (Ed.), Amer. Chemical Soc. Symposium Series 93, Amer. Chemical Soc. (1979). 
Clebsch A., Jr.. "Tritium-Age of Ground water at the Nevada Test Site, Nye County, Nevada," U. S. Geological Survey Professional Paper 424-C. Arificle 194 (1961).

Clebsch, A., Jr. and F. B. Barker, "Analysis of Ground Water from Rainier Mesa, Nevada Test Site, Nye County, Nevada," U. S. Geological Survey Trace Elements Investigations Report 763 (TEI-763) (May 1960).

Craig, H., "Isotopic Variations in Meteoric Waters," Science, 133, 1702-1703 (1961).

Craig, R. W. and J. H. Robison, "Geohydrology of Rocks Penetrated by Test Well UE-25p\#1, Yucca Mountain Area, Nye County, Nevada," U. S. Geological Survey Water-Resources Investigations Report 84-4248 (1984).

Crowe, B. M. and D. T. Vaniman, "Research and Development Related to the Nevada Nuclear Waste Storage Investigations, January 1 - March 30, 1984, "Los Alamos National Laboratory report LA-10154-PR (February 1985).

Czarnecki, J. B., "Simulated Effects of Increased Recharge on the Ground-Water Flow System of Yucca Mountain and Vicinity, Nevada-California," U. S. Geological Survey Water-Resources Investigations Report USGS/WRI-84-4344 (1985).

Daniels, W. R., K. Wolfsberg, R. S. Rundberg, A. E. Ogard, J. F. Kerrisk, C. J. Duffy, et al.. "Summary Report on the Geochemistry of Yucca Mountain and Environs," Los Alamos National Laboratory report LA-9328-MS (December 1982).

Daniels, W R., B. R. Erdal, and D. T. Vaniman, "Research and Development Related to the Nevada Nuclear Waste Storage Investigations, July 1 - September 30, 1982," Los Alamos National Laboratory report LA-9577-PR (March 1983).

Dansgaard, W., "Stable Isotopes in Preripitation," Tellus, XVI, 436-468 (1964).

Drever, J. I., The Geochemistry of Natural Waters, (Prentice-Hall, Inc., Englewood Cliffs, New Jersey, 1982).

Faure, G., Principles of Isotope Geology (John wiley and Sons, New York, 1977), pp. 323-401.

Feth, J. H., "Nitrogen Compounds in Natural Water - A Review," Water Resources Research, 2, 41-58 (1966).

Fritz, P. and J. Ch. Fontes, Handbook of Environmental I sotope Geochemistry, Vol. 1, The Terrestrial Environment, A (Elsevier Scientific Publishing Co., New York, 1980).

Haas, H., D. W. Fisher, D. C. Thorstenson, and E. P. Weeks, $" 13 \mathrm{CO}_{2}$ and $14 \mathrm{CO}_{2}$ Measurements on Soll Atmosphere Sampled in the Sub-Surface Unsaturated Zone in the Western Great Plains of the US," Radiocarbon, 25, 301-314 (1983).

Henne, M. S., "The Dissolution of Rainier Mesa Volcanic Tuffs, and Its Application to the Analysis of the Groundwater Environment," M. S. Thesis, University of Nevada, Reno (1982). 
Hoover, D. L., "Genisis of Zeolites, Nevada Test Site," in Nevada Test Site, E. B. Eckel, Ed., Geological Society of America Memoir 110, 275-283 (1968).

Kerrisk, J. F., "Reaction-Path Calculations of Groundwater Chemistry and Mineral Formation at Rainier Mesa, Nevada," Los Alamos National Laboratory report LA-9912-MS (December 1983).

Kerrisk, J. F., "Solubility Experiments for the Nevada Nuclear Waste Storage Investigations Project," LoS Alamos National Laboratory report LA-10560-MS (November 1985).

Lindberg, R. D. and D. D. Runnells, "Ground Water Redox Reactions: An Analysis of Equilibrium State Applied to Eh Measurements and Geochemical Modeling," Science, 225, 925-927 (1984).

Mayewski, P. A., W. B. Lyons, M. J. Spencer, M. Twickler, W. Dansgaard, B. Koci, C. I. Davidson, and R. E. Honrath, "Sulfate and Nitrate Concentrations for a South Greenland Ice Core," Science, 232, 975-977 (1986).

Means, J. L., A. S. Maest, and D. A. Crerar, "The Organic Geochemistry of Deep Groundwaters and Organo-Radionuclide Interactions at Hydrothermal Conditions," Office of Nuclear Waste Isolation report ONWI-448 (September 1982).

Mendel, J. E., (Comp.), "Final Report of the Defense High-Level Waste Leaching Mechanisms Program," Pacific Northwest Laboratory report PNL-5157 (August 1984).

Moncure, G. K., R. C. Surdam, and H. L. McKague, "Zeolite Diagenesis Below Pahute Mesa. Nevada Test Site," Clays and Clay Minerals, 29, 385-395 (1981).

Montazar, P. and W. E. Wilson, "Conceptual Hydrologic Model of Flow in the Unsaturated Zone, Yucca Mountain, Nevada," U. S. Geological Survey Water-Resources Investigations Report 84-4345 (1984).

Nitsche, H., and N. M. Edelstein, "Determination of the Solubilities and Complexation of Waste Radionuclides Pertinent to Geologic Disposal at the Nevada Tuff Site," Lawrence Berkeley Laboratory report LBL-18900 (January 1985).

Ogard, A. E., W. R. Daniels, and D. T. Vaniman, "Research and Development Related to the Nevada Nuclear Waste Storage Investigations, October 1 December 31, 1982," Los Alamos National Laboratory report LA-9666-PR (May 1983).

Ogard, A. E. and J. F. Kerrisk, "Groundwater Chemistry Along Flow Paths Between a Proposed Repository Site and the Accessible Environment, "Los Alamos National Laboratory report LA-10188-MS (November 1984).

Ogard A. E. and D. T. Vaniman, "Research and Development Related to the Nevada Nuclear Waste Storage Investigations, July 1 - September 30, 1984," Los Alamos National Laboratory report LA-10299-PR (May 1985). 
Robison, J. H., "Ground-Water Level Data and Preliminary Fotentiometric-Surface Maps, Yucca Mountain, Nye County, Nevada," U. S. Geological Survey Water-Resources Investigations Report 84-4197 (1984).

Rundberg, R. S., A. E. Ogard, and D. T. Vaniman, "Research and Development Related to the Nevada Nuclear Waste Storage Investigations, April i - June 30 , 1984," Los Alamos National Laboratory report LA-10297-PR (May 1985).

Spaulding, W. G., "Vegetation and Climates of the Last 45,000 years in the Vicinity of the Nevada Test Site, South-Central Nevada," U. S. Geological Survey Professional Paper 1329 (1985).

Stumm, W., and J. J. Morgan, Aquatic Chemistry (John Wi ley and Sons, New York, $1981)$ p. 236.

Thorstenson, D. C., E. P. Heeks, H. Haas, and D. W. Fisher, "Distribution of Gaseous $12 \mathrm{CO}_{2}, 13 \mathrm{CO}_{2}$, and $14 \mathrm{CO}_{2}$ in the Sub-Soil Unsaturated zone of the Western US Great Plains," Radiocarbon, 25, 315-346 (1983).

Vaniman, D. T., "Progress Report on Research Conducted by the Earth and Space Science Division, Los Alamos National Laboratory, In Support of the Nevada Nuclear Waste Storage Investigations, January-June, 1985," Los Alamos National Laboratory report in preparation (1986).

Waddell, R. K., J. H. Robison, and R. K. Blankennage 1, "Hydrology of Yucca Mountain and Vicinity. Nevada-California -- Investigative results through Mid-1983," U. S. Geological Survey Water-Resources Investigations Report 84-4267 (1984).

Wairen, R. G. and D. E. Broxton, "Chemical Composition of Hydrated Glasses in Rock Units of the Nevada Test Site." Los Aiamos National Laboratory report in preparation (1986).

White, A. F., "Geochemistry of Ground water A.ssociated with Tuffaceous Rocks, Oasis Valley. Nevada," U. S. Geological Survey Professional Paper 712-E (1979).

White, A. F. and N. J. Chuma, "Isotope and Carbon Models of the Oasis Valley-Fortymile Canyon Ground Water Basin, Nevada," to be published in Water Resources Research (1986).

White, A. F., H. C. Claassen, and L. V. Benson, "The Effect of Dissolution of Volcanic Glass on the Water Chemistry in a Tuffaceous Aquifer, Rainier Mesa, Nevada," U. S. Geological Survey Water-Supply Paper 1535-Q (1980).

Wigley, T. M. L., L. N. Plummer, and F. J. Pearson, Jr., "Mass Transfer and Carbon Isotope Evolution in Natural Water Systems," Geochimica et Cosmochimica Acta, 42, 1117-1139 (1978).

Winograd, I. J. and W. Thordarson, "Hydrologic and Hydrochemical Framework. South-Central Great Basin,. Nevada-California, with Special Reference to the Nevada Test Site," U. S. Geological Survey Professional Paper 712-C (1975). 
Wolery, T. J., "EQ3NR, A Computer Program for Geochemical Aqueous

Speciation-Solubility Calculations: Users Guide and Documentation, "Lawrence Livermore Naticna! Laboratory report UCRL-53414 (April 1983).

Wolfsberg, K. and D. T. Vaniman, "Research and Deve?cpment Related to the Nevada Nuclear Waste Storage Investigations, October I - Eecembe" 31, 1983," Los Alamos National Laboratory report LA-10032-PR (August 1984).

Yang, In C., H. H. Haas, E. P. Weeks, D. C. Thorstenson, "Analys is of Gaseous-Phase Stable and Radioactive Isotopes in the Unsaturated Zone, Yucca Mountain. Nevada," Proc. National Water Well Association Conf. On Characterization and Monitoring the Vadose Zone, Denver, Colorado, November $19-21,1985$.

Yarig, In C., U. S. Geological Survey, private communication (1986).

Young, R. A., "Water Supply for the Nuclear Rocket Development Station at the U. S. Atomic Energy Commission's Nevada Test Site," U. S. Geological Survey Water-Supply Paper 1938 (1972). 
Th1s appendix contains a list of the water chemistry data reviewed for this report. The list is in the form of a SASO output listing from the data base used to prepare the data for the plots contained in the report.

The various column headings in the data listing are described here. SITE refers to the well, spring, or sampling location where the water sample was obtained. REFERENCE refers to the source of the data; the references listed under this heading are in the reference section of the report. LOCATION refers to the location of the sampling site; the abbreviations used under this heading are listad in Table II of the report. DATE refers to the sampling date. INT SAMP (M) refers to the depth iriterval sampled in meters for wells; under this heading the entry INT refers to an integral well sample, in which the entire well bore was pumped, or to an integral sample taken from some other source such as a spring or seep. LITHOLOGY refers to the primary 11 thology of the well or the area sampled; under this heading I means tertiary rock, $\subseteq$ means carbonate (Paleozoic) rock, QAL means quaternary alluvium, BULL means Bullfrog, and SOIL means soil zone. SURFACE ALTITUDE (M) refers to the ground surface elevation above sea level in meters at the well or sampling site. WELL DEPTH (M) refers to the depth of the well in meters. DEPTH TO WATER (M) refers to the depth to the static water level in the well in meters. TEMP (C) refers to the water temperature in ${ }^{\circ} \mathrm{C}$. The headings $\underline{C A}, \underline{M G}$, $\underline{\mathrm{NA}}, \underline{K}, \underline{\mathrm{CL}}, \underline{\mathrm{SO}} 4, \underline{\mathrm{SIO}}, \underline{\mathrm{F}}, \underline{\mathrm{NO} 3}$, and $\mathrm{HCO} 3$, refer to the concentrations of calcium, magnesium, sodium, potassium, chloride, sulfate, aqueous silica, fluoride, nitrate, and total carbonate in mmoles/l. PH refers to water $\mathrm{pH}$. $\underline{02}(M G / L)$ refers to dissolved oxygen in $\mathrm{mg} / 1$. DEL $D$ refers to $S D$ in $\%$. DEL 018 refers to $\delta^{18} 0$ in $\%$ DEL Cl3 refers to $\delta^{13} \mathrm{C}$ in $\%$. PMC refers to percentage of modern carbon in \%. LOG(CO2 PRESS) refers to $\log _{10}$ (carbon dioxide pressure in atm). CALCITE LOG(Q/K), DOLOMITE LOG(Q/K), GYPSUM LOG(Q/K), MAGNESITE LOG(Q/K), and FLUORITE LOG(Q/K) refer to the $\log _{10}(\mathrm{Q} / \mathrm{K})$ for calcite, dolomite, gypsum, magnesite, and fluorite; the meaning of $\log _{10}(Q / K)$ is discussed in section VI(A) of this report and in stumm and Morgan (1981). A blank or period (.) under any heading indicates that no data were available. 
SITE

WELL $J-12$

WELL $J-13$

WELL UE-25BH

WELL UE-25BH

WELL UE-25BHI

WELL UE-25CH

WEI.L UI - 25CH2

WELL UE - 25CH3

WELL UE - 25P

WELL UE - 25PH

WELL UE-29AH2

WELL UE - 29AH

WELL USW G-4

WE.LL USW $\mathrm{H}-1$

WELL USW H-1

WELL USW $\mathrm{H}-3$

WELL USW H-4

WELL USW H-5

WELL USW H-G

WELL USW H-G

WELL

WELL USW VH-1

WELL USW VH-1

3. $155 / 49 E \cdot 22 D C$

4. $165 / 49 E-5 A C C$

5. $165 / 49 E-8 A B B$

6. $165 / 49 E-B A C C$

7. 16S/49E - $A C D A$

7. $16 S / 49 E-9 C D A$

8. $16 S / 49 E-9 D C C$

9. 16S/49E - 1BDC

1C. $16 S / 49 E-16 C C C$

11. 165/49E - 19DAA

12, 16S/48E-24AAA

13. 16S/48E - 25AA

14, 16S/48E-36AAA

15. $7 \mathrm{~S} / 4 \mathrm{BE}-1 \mathrm{AB}$

16. $175 / 49 E-7 B B$

17. $175 / 49 E-9 A A$

18. $175 / 49 E-B D D B$

19. $17 \mathrm{~S} / 49 \mathrm{E}-15 \mathrm{BBD}$

64. WELL 8 , NTS

20. $17 \mathrm{~S} / 49 \mathrm{E}-35 D D D$. ASH TR

21. $165 / 49 E-23 A D D$

23, 16S/ $4 B E$ - 15AAA

25. $16 S / 48 E-1 O C B A$

27. $16 \mathrm{~S} / 50 \mathrm{E}-7 \mathrm{BCD}$

29. 16S/49E - 15AAA

30, 16S/49E - 36AAA

45. 16S/4BE-8BBA

$46,16 S / 48 E-7 B B A$

47. $165 / 48 E-7 C B C$

48 . $16 \mathrm{~S} / 48 \mathrm{AB}-18 \mathrm{BCC}$
REFERENCE

BENSON AND MCKINLEY (1985), OGARD AND KERRISK (1984) BENSON AND MCKINLEY (1985); UGARD AND KERRISK $(1984)$ BENSON AND MCKINLEY (1985); OGARD AND KERRISK (1984) BENSON AND MCKINLEY (1985), OGARD AND KERRISK (1984) BENSON AND MCKINLEY (1985), OGARD AND KERRISK (1984)

BENSON AND MCKINIEY (19B5)

BENSON AND MCKINLEY (1985)

BENSDN AND MCKINLEY (1985)

BENSON AND MCKINLEY (1985) OGARO AND KERRISK (1984) BENSON AND MCKINIEY (1985) OGARD AND KERRISK (1984) BENSON AND MCKINLEY (1985), OGARD AND KERRISK (1984) BENSON ANO MCKINLEY (1985), OGARD AND KERRISK (1984) BENSON AND MCKINLEY (1985), OGARD AND KERRISK (1984) BENSON AND MCKINLEY (1985).

BENSON AND MCKINLEY (1985)

BENSON AND MCKINLEY (1985), OGARD AND KERRISK (1984) BENSON AND MCKINLEY (1985). OGARD AND KERRISK (1984) BENSON AND MCKINTEY ( BENSON AND MCKINLEY ( 1985). OGARD AND KERRISK (19BA) BENSON AND MCKINLEY (1985), OGARD AND KERRISK (1984) BENSON AND MCKINLEY (1985). BENSON ANO MCKINLEY (1985), OGARD AND KERRISK (1984) BENSON AND MCKINLEY (1985)

BENSON AND MCKINLEY (1985)

BENSON AIIO MCKINIEY (1985)

CLAASSEN ( 1985)

CLAASSEN (1985)

CLAASSEN ( 1985$)$

CLAASSEN (1985)

CLAASSEN (1985)

CLAASSEN (1985)

CLAASSEN (1985)

CLAASSEN (1985)

CLAASSEN (1985)

CLAASSEN (1985)

CLAASSEN (1985)

CLAASSEN (1985)

CLAASSEN (1985)

CLAASSEN (1985)

CLAASSEN (1985)

CLAASSEN (1985)

CLAASSEN (1985)

CLAASSEN (1985)

CLAASSEN (1985)

CLAASSEN (1985)

CLAASSEN (1985)

CLAASSEN (1985)

CLAASSEN (1985)

CLAASSEN (1985)

CLAASSEN (1985)

CLAASSEN (1985)

CLAASSEN (1985)

CLAASSEN (1985)

CLAASSEN (1985)

CLAASSEN (1985) 
SITE

$49,165 / 48 E-17 \mathrm{CCC}$

50, $16 S / 48 E-18 D A D$

51, $16 S / 48 E-8 C D A$

52, 16S/48E - 17ABB

62. WHITEROCK SPRING

Eg. BUTTE SPRING

70. DAK SPRING

71. TOPOPAH SPRING

1. 105/47E - 148AB

2. $10 S / 47 E-27 C B A$

3. $10 S / 47 E-31 A A B$

4. 1OS/47E-32DDA

5. $105 / 47 E-33 A A B$

6. $10 S / 47 E-300 C C$

7. $115 / 46 E-26 B B B$

8 , $10 S / 46 E-26 B C C$

9. $115 / 47 E-3 C D B$

10. $11 \mathrm{~S} / 47 \mathrm{E}-4 \mathrm{CAD}$

11. 1 iS/47E - 1OCAA

12, $11 S / 47 E-1 O B C C$

13. 11S/47E- 16DCD

14, $11 \mathrm{~S} / 47 \mathrm{E}-16 \mathrm{BDC}$

15. $115 / 47 E-18 A C D$

16. $115 / 47 E-21 A C C$

16. 11S/47E - 1 IACC

17. IIS/47E-2 IDBB

18. ITS/A7E - 1 IABA

19, 11S/47E - 2 1ABA

20. $115 / 47 E-27 C B A$

21. 11S/47E-2BAAC

22 , $11 \mathrm{~S} / 47 \mathrm{E}-28 \mathrm{DAC}$

23. 115/47E - 338AC

24. $11 \mathrm{~S} / 47 \mathrm{E}-10 \mathrm{CCB}$

25. $125 / 47 E-5 C D A$

26. $125 / 47 E-6 C D D$

27. $125 / 47 E-70 B D$

$27.125 / 47 E-70 B D$
$28,125 / 47 E-20 B B B$

$28,12 S / 47 E-2 O B B B$
$29,12 S / 47 E-19 A D C$

18B. $125 / 47 \mathrm{E}-20$

19B, 125/47E-20

$208,125 / 47 E-20$

218: $125 / 47 \mathrm{E}-20$

$22 B, 125 / 47 E-20$

WELL UE-19B-1

WELL UE-19C

WELL UE-19D

WELL UE-19E

WELL UE-19E

WELL UE-19GS

WELL UE-19GS

WELL U-2OA-2

WELL $U-2 O A-2$
REFERENCE

CLAASSEN (1985)

CLAASSEN (1985)

CL $\therefore$ ASSEN ( 1985 )

CLAASSEN ( 1985 )

CLAASSEN (1985)

CLAASSEN (1985)

CLAASSEN (1985)

CLAASSEN (1965)

WHITE (1979)

WHITE (1979)

WHITE (1979)

WHITE (1979)

WHITE (1979)

WHITE (1979)

WHITE (1979)

WHITE (1979)

WHI TE (1979)

WHI TE (1979)

WHI TE (1979)

WHI TE (1979)

WHITE (1979)

WHITE (1979)

WHITE (1979)

WHITE (1979)

WHITE (1979)

WHITE (1979)

WHITE ( 1979$)$

WHITE (1979)

WHITE (1979)

WHITE (1979)

WHITE (1979)

WHITE (1979)

WHITE (1979)

WHITE (1979)

WHITE (1979)

WHITE (1979)

WHITE (1979)

WHITE (1979)

WHITE AND CHUMA (1986)

WHITE AND CHUMA (1986)

WHITE AND CHUMA (1986)

WHITE AND CHUMA (1986)

WHITE AND CHUMA (1986)

BLANKENNAGEL AND WEIR (1973)

BLANKENNAGEL AND WEIR (1973)

BLANKENNAGEL AND WEIR (1973)

BLANKENNAGEL AND WEIR (1973)

CLAASSEN (197.3)

BLANKENNAGEL AND WEIR (1973)

CLAASSEN (1973)

BLANKENNAGEL AND WEIR (1973)

CLAASSEN (1973)

BLANKENNAGEL AND WEIR (1973)

BLANKENNAGEL AND WEIR (1973)

BLANKFNNAGEL AlND WEIR (1973) 
SITE

WELL UE-20J

WELL ARMY - 1

WELL 5A

WELL 5B

WELL 5C

WELL' $C$

WELL C - 1

WELL 3

WELL A

WELL 2

WELL UE-15D

UE 12TH3-5, 134.4 (M)

UE 12TH3-6, 169.6(M)

UE 12TH3-7, 199.2(M)

UE 12TH3-B, $202.4(M)$

UE $12 T H 3-9,257.6(M)$

JE 12TH3-10, 260.O(M)

UE 12T\#3-11.441.4(M)

UE 12T $\# 3-12,442.4(M)$

UE 12TH3-13, 291.4(M)

UE $12 T H 3-14,320.3(M)$

UE 12TH3-15, 320.6(M)

UE 12TH3-16, 320.6(M)

UE 12TA3-16, 321.3(M)

UE 12TH3-17, 350.8(M)

UE $12 T H 3-18,411.2(\mathrm{M})$

UE 12T $\# 3-19,470.6(M)$

UE 12T\#3-20，472.4(M)

LE 12TH3-21, 501.7(M)

UE 12TH3-22, 503. 2 (M)

UE 12TH3-23, $532.8(M)$

RML 1A, SURFACE

RML 1B, SURFACE

1. U12N.O5 BYPASS

2. U12N.O5

3. U12N.O5

4. U12N MAIN

5. U12N.O7 BYPA5S

6. U12N.02

7. U12T.02 BYPASS

8. U $12 T .02$

9. U12T.O2 BYPASS

10. U12T MAIN

11. U12T.03

12. U12T.03

13. U12T. 04

14. U12T.03

15. U12T.03

16. U12T.03

17. U12E.07

18. U12E.04

19. U12E

20, U12E

$21, U 12 E .04$

22, U12E.03
REFERENCE

BLANKENNAGEL AND WEIR (1973)

CLAASSEN ( 1973 )

CLAASSEN (1973)

CLAASSEN (1973)

CLAASSEN (1973)

CLAASSEN ( 4973 )

CLAASSEN (1973)

CLAASSEN (1973)

CLAASSEN (1973)

CLAASSEN (1973)

CLAASSEN (1973)

BENSON (1976)

BENSON (1976)

BENSON (1976)

BENSON ( 1976 )

BENSON (1976)

BENSON (1976)

BENSON (1976)

BENSON (1976)

BENSON (1976)

BENSON (1976)

BENSON (1976)

BENSON (1976)

BENSON $(1976)$

BENSON (1976)

BENSON ( 1976$)$

BENSON (1976)

BENSON (1976)

BENSON (1976)

BENSON (1976)

BENSON (1976)

BENSON (1976)

BENSON (1976)

WHITE, CLAASSEN AND BENSON (1980)

WHITE, CLAASSEN AND BENSON (1980)

WHITE, CLAASSEN AND BENSON (19BO)

WHITE, CLAASSEN AND BENSON (1980)

WHITE, CLAASSEN AND BENSON (1980)

WHITE; CLAASSEN AND BENSON (1980)

WHITE, CLAASSEN AND BENSON (1980)

WHITE, CLAASSEN AND BENSON (1980)

WHITE, CLAASSEN AND BENSON (1980)

WHITE, CLAASSEN AND BENSON (1980)

WHITE, CLAASSEN AND BENSGN (1980)

WHITE, CLAASSEN AND BENSON (1980)

WHITE, CLAASSEN AND BENSON (1980)

WHITE, CLAASSEN AND BENSON (1980)

WHITE, CLAASSEN AND BENSON (1980)

WHITE, CLAASSEN ANO BENSON (19BO)

WHITE CLAASSEN AND BENSON (198O)

WHITE, CLAASSEN AND BENSON (1980)

WHITE; CLAASSEN ANO RENSON (1990)

WHITE, CLAASSEN AND RENSON (1980) 
SITE

23. U12E

24. U12E.02

25, U12E. 05

26, U12E.03

27. U12E.O3

28. U12E.03

29. U12E.O

30. U12E

31. U12E

$32, U 12 E$

33. U12E

34. U12B

35. U128.03

$36, U 12.04$

SEEP 1, U12T

SEEP 2, U12N, 03

SEEP 3, U12N. D5

SEEP 4, U12N.O3

LYSIMETER 1. U12N.05

LYSIMETER 2. U12N. O5

LYSIITETER 3, U12N.O5

LYSIMETER 4, U12N.05

LYSIMETER 5. U12N.05

LYSIMETER 6. SURF SOIL

L.YSIMETER 7. SURF SOIL

LYSIMETER 9 , SURF SOIL

ANAL 2589, TUNNEL U128. E

ANAL 2819. TUNNEL U128, D

ANAL 2913. TUNNEL U12E, D

ANAL 3260. TUNNEL U12E. D

ANAL 3541, TUNNEL U12E,

$\mathbf{N}=$

193

\section{REFERENCE}

WHITE, CLAASSEN AND BENSON (1980) WHITE, CLAASSEN AND BENSON (1980) WHITE, CLAASSEN AND BENSON (1980)

WHITE, CLAASSEN AND BENSON (1980)

WHITE, CLAASSEN AND BENSON $(1980)$

WHITE, CLAASSEN AND BENSON (1980)

WHITE, CLAASSEN AND BENSON (1980)

WHITE, CLAASSEN AND BENSON (1980)

WHITE, CLAASSEN AND BENSON (1980)

WHITE, CLAASSEN AND BENSON (1980)

WHITE, CLAASSEN AND BENSON (1980)

WHITE, CLAASSEN AND BENSON (1980)

WHITE, CLAASSEN AND BENSON (1980)

WHITE, CLAASSEN AMD BENSON (1980)

HENNE (1982)

HENNE (1982)

HENNE (1982)

HENNE (1982)

HENNE (1982)

HENNE (1982)

HENNE (1982)

HENNE (1982)

HENNE (1982)

HENNE ( 1982$)$

HENNE (1982)

HENNE (1982)

CLEBSCH AND BARKER (1960)

CLEBSCH AND BARKER (1960)

CLEBSCH AND BARKER (1960)

CLEBSCH AND BARKER (1960)

CLEBSCH AND BARKER ( 1960$)$ 
WELL $J-12$

WELL J-13

WELL UE - 25BA

WELL UE-25BA 1

WELL UE-25BA

WELL UE - 25CA

WELL LE-25CH

WELL UE-25P\#1

WELL UE-25PAI

WELL UE - 29AH2

WELL UE-29AA2

WFLL USW G-4

WELL USW $\mathrm{H}-1$

WELL USW $\mathrm{H}-1$

WELL USW H-3

WELL USW $H-4$

WELL USW H-5

WELL UISW H-5

WELL USW H-6

WELL USW H-6

WELL USW H-6

WELL USW VH-1

WELL USW VH-1

WELL USW VH-1

3. $15 S / 49 E-220 C$

4, 16S/49E - 5ACC

5. $16 S / 49 E-8 A B B$

6. $16 S / 49 E-8 A C C$

7. 16S/49E - 9CDA

B. $16 S / 49 E-9 D C C$

10. $165 / 49 E-180 C$

10. 16S/49E-16CCC

12. 16S/49E - 19DAA

13. $165 / 48 E-25 A A$

14. $165 / 4 B E-36 A A A$

15. $175 / 4 B E-1 A B$

16, $17 \mathrm{~S} / 49 \mathrm{E}-7 \mathrm{BB}$

17. 175/49E-9AA

18. $175 / 49 E-8 D D B$

64. WELL 8 NTS

20. $175 / 49 E-35 D D D, A S H ~ T R$

21. 16S/49E

21.

23. 16S/4BE - I5AAA

$25.16 S / 48 E-10 C B A$

29. 16S/49E - 15AAA

$30,16 S / 49 E-36 A A A$

45, $165 / 48 E-B B B A$

46. 16S/48E-7BBA

\begin{tabular}{|c|c|c|c|}
\hline FMW & $03 / 26 / 71$ & INT & $T$ \\
\hline FMW & $03 / 26 / 71$ & INT & $\mathrm{T}$ \\
\hline YM & $08 / 07 / 81$ & INT & $\mathbf{T}$ \\
\hline YM & $09 / 01 / 81$ & INT & $T$ \\
\hline$Y M$ & $07 / 20 / 82$ & $863-875$ & $T$ \\
\hline$Y M$ & $09 / 30 / 83$ & INT & $\mathbf{T}$ \\
\hline$Y M$ & $03 / 13 / 84$ & INT & $\mathbf{T}$ \\
\hline$Y M$ & $05 / 09 / 84$ & INT & $\mathbf{T}$ \\
\hline YM & $02 / 09 / 83$ & $381-1197$ & $T / C$ \\
\hline YM & $05 / 12 / 83$ & $1297-1805$ & c \\
\hline YM & $01 / 08 / 82$ & $247-354$ & $\mathbf{T}$ \\
\hline$Y M$ & $01 / 15 / 82$ & $87-2.13$ & $\mathbf{T}$ \\
\hline$Y M$ & $12 / 09 / 82$ & INT & $\mathbf{T}$ \\
\hline YM & $10 / 20 / 80$ & $572-687$ & $T$ \\
\hline YM & $12 / 08 / 80$ & $687-1829$ & $T$ \\
\hline$Y M$ & $03 / 14 / 84$ & $822-1220$ & $T$ \\
\hline YM & $05 / 17 / 82$ & INT & $T$ \\
\hline$Y M$ & $07 / 03 / 82$ & I NT & $T$ \\
\hline$Y M$ & $07 / 26 / 82$ & INT & $T$ \\
\hline$Y M$ & $10 / 16 / 82$ & INT & $T$ \\
\hline$Y M$ & $06 / 20 / 84$ & $753-835$ & $T$ \\
\hline$Y M$ & $07 / 06 / 84$ & $608-646$ & $T$ \\
\hline CF & $02 / 06 / 81$ & INT & $T$ \\
\hline CF & $02 / 0 B / 81$ & INT & $\mathrm{T}$ \\
\hline$C F$ & $02 / 11 / 81$ & INT & $T$ \\
\hline AU/FMW & $11 / 20 / 72$ & INT & $T / C ?$ \\
\hline$A D / F M W$ & $03 / 04 / 74$ & INT & \\
\hline$A D / F M W$ & $11 / 17 / 72$ & INT & $\mathrm{T} / \mathrm{C}$ ? \\
\hline$A D / F M W$ & $04 / 01.71$ & INT & \\
\hline$A D / F M W$ & $11 / 18 / 72$ & INT & \\
\hline$A D / F M W$ & $03 / 01 / 74$ & INT & $T / C ?$ \\
\hline$A D / F M W$ & $03 / 01 / 74$ & INT & \\
\hline$A D / F M W$ & $06 / 26 / 79$ & INT & $\mathrm{T} / \mathrm{C} ?$ \\
\hline$A D / F M W$ & $03 / 05 / 74$ & INT & $T$ \\
\hline$A D / F M W$ & $11 / 17 / 72$ & INT & \\
\hline$A D / F M W$ & $03 / 05 / 74$ & INT & $\mathbf{T}$ \\
\hline$A D / F M W$ & $03 / 04 / 74$ & INT & $T$ \\
\hline AD/FMW & $03 / 05 / 74$ & INT & $\mathbf{T}$ \\
\hline$A D / F M W$ & $03 / 01 / 74$ & INT & $T / C$ \\
\hline$A D / F M W$ & $03 / 01 / 74$ & INT & $\mathrm{T} / \mathrm{C} ?$ \\
\hline$A D / F M W$ & $03 / 06 / 74$ & INT & $\mathbf{T}$ \\
\hline$A D / F M W$ & $03 / 06 / 74$ & INT & $\mathrm{T} / \mathrm{C}$ \\
\hline RM & $03 / 24 / 71$ & INT & $T$ \\
\hline$A D / M I S C$ & $03 / 06 / 74$ & INT & $\mathbf{T}$ \\
\hline AD/INT & $06 / 25 / 79$ & INT & $T$ \\
\hline$A D / I N T$ & $03 / 31 / 71$ & INT & $\mathrm{T}$ \\
\hline$A D / I N T$ & $03 / 31 / 71$ & INT & $\mathbf{T}$ \\
\hline$A D / M I S C$ & $04 / 01 / 71$ & INT & $\mathrm{C} / \mathrm{T} ?$ \\
\hline AD/MISC & $03 / 31 / 71$ & INT & $C / T$ \\
\hline$A D / M I S C$ & $06 / 24 / 79$ & INT & $\mathrm{C} / \mathrm{T} ?$ \\
\hline$A D / O V$ & $06 / 24 / 71$ & INT & \\
\hline$A D / O V$ & $03 / 30 / 71$ & INT & \\
\hline
\end{tabular}


INT

$47,16 \mathrm{~S} / 48 \mathrm{~B}-7 \mathrm{CBC}$

48, $16 S / 48 E-18 B C C$

49, $165 / 4 B E-17 C C C$

50. $165 / 48 E-j B D A D$

51. 16S/4BE-BCDA

52. $6 S / 48 E-17 A B B$

62. WHITEROCK SPRING

68. BUTTE SPRING

70, DAK SPRING

71. TOPOPAH SPRING

1. $10 S / 47 E-14 B A B$

2 , $105 / 47 E-27 \mathrm{CBA}$

3. $10 S / 47 E-31 A A B$

4. $10 S / 47 E-32 D D A$

5. 1OS/47E-33AAB

$6,10 S / 47 E-3 O D C C$

$7,11 S / 46 E-26 B B B$

8. $105 / 46 E-26 B C C$

9. $115 / 47 E-3 C D B$

10. 115/47E-4CAD

11. 11S/47E- 1OCAA

12. $11 \mathrm{~S} / 47 \mathrm{E}-10 \mathrm{BCC}$

13. $115 / 47 E-16 D C D$

14. $11 S / 47 E-16 B D C$

15, $11 \mathrm{~S} / 47 \mathrm{E}-18 \mathrm{ACD}$

16. $11 \mathrm{~S} / 47 \mathrm{E}-21 \mathrm{ACC}$

17. $11 \mathrm{~S} / 47 \mathrm{E}-2$ 1DBB

18, $115 / 47 E-21 A B A$

19. 11S/47E-2 IABA

$20,115 / 47 E-27 C B A$

21. 11S/47E-2BAAC

$22,115 / 47 E-2 B D A C$

23. $11 \mathrm{~S} / 47 \mathrm{E}-33 \mathrm{BAC}$

24, 11S/47E-1OCCB

25. 12S/47E - 5CDA

26. 12S/47E-6CDD

27. $12 S / 47 E-7 D B D$

$2 B, 125 / 47 E-2 O B B B$

29, 12S/47E-19ADC

18B, $125 / 47 E-20$

19B. 12S/47E-20

2OB, $12 S / 47 E-20$

$21 B, 12 S / 47 E-20$

$22 B, 125 / 47 E-20$

WELi UE-19B-1

WELL UE-19C

WELL UE - 19D

WELL UE-19E

WELL UE-19E

$\infty$

WELL UE-19GS

WELL UE-19GS

WELL U-2OA-2

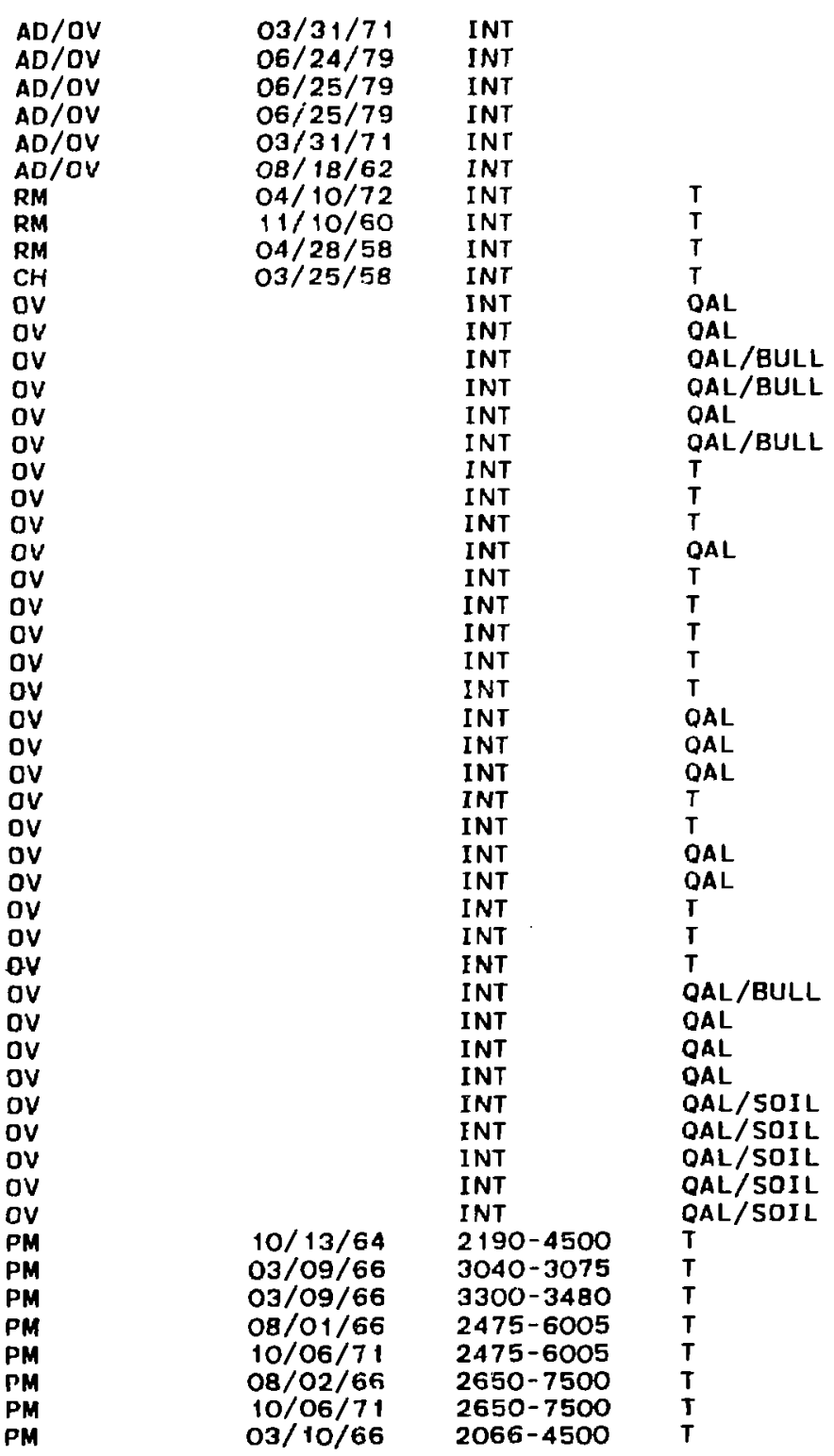


WELL U-2OA-2

WELL UE-2OD

WELL UE-2OE-1

WELL UE $-2 \mathrm{OH}$

WELL UE-2OJ

WELL ARMY -

WELL SA

WELL 5B

WELL 5C

WELL C

WELL $\mathrm{C}-$

WFLL A

WELL 2

WELL UE - 150

UE 12TH3-5, 134. 4 (M)

UE $12 T H 3-6,169.6(M)$

UE $12 T$ T 3-7, 199.2 (M)

UE 12 TH3-8, 202.4 (M)

UE 12TH3-9, 257.5(M)

UE 1 TTH3-10, 260.O(M)

UE $12 T H 3-11,441.4(M)$

UE 12TH3-12, 442.4 (M)

UE 12TH3-13, 291.4(M)

UE 12T\#3-14, 320.3(M)

UE 12TH3-15, 320.6(M)

UE 12T\#3-16, 321.3(M)

JE 12TH3-17, 350.8(M)

UE $12 T H 3-18,411.2(M)$

UE 12TH3-19, 470.6 (M)

UE 12TH3-20: $472.4(\mathrm{M})$

UE 12TH3-22, 503.2(M)

UE 12TH3-23, 532 .8(M)

RML IA, SURFACE

RML IB SURFACE

1. UI2N. OS BYPASS

2. U12N.05

3. U12N.O5

4. UI2N MAIN

5. U12N.O7 BYPASS

6. U12N.02

7. U12T.02 BYPASS

8. U12T.02

9. U12T.O2 BYPASS

10. U12T MAIN

11. U12T.O3

12, U12T.O3

13. U12T.04

14, U12T.03

15. U12T.03
$P M$

$P M$

PM

$P M$

FF

$F F$

$F F$

$Y F$

YF

$Y F$

YF

RM/PW

RM/PW

RM/PW

$\mathrm{RM} / \mathrm{PW}$

$\mathrm{RM} / \mathrm{PW}$

$\mathbf{R M} / \mathrm{PW}$

$\mathrm{RM} / \mathrm{PW}$

RM/PW

RM/PW

$\mathbf{R M} / \mathbf{P W}$

$R M / P W$

RM/PW

$R M / P W$

$\mathrm{RM} / \mathrm{PW}$

$\mathrm{RM} / \mathrm{PW}$

$\mathrm{RM} / \mathrm{PW}$

RM/PW

RM/PW

RM/PW

$\mathrm{RM} / \mathrm{PW}$

$\mathrm{RM} / \mathrm{PW}$

$\mathrm{RM} / \mathrm{PW}$

RM/PW

RM/FW

$\mathrm{RM} / \mathrm{FW}$

$\mathrm{RM} / \mathrm{FW}$

RM/FW

RM/FW

RM/FW

$R M / F W$

$R M / F W$
$R M / F W$

$R M / F W$

RM/FW

RM/FW

$R M / F W$

RM/FW

RM/FW

$\mathrm{RM} / \mathrm{FW}$

RM/FW

RM/FW

\section{(M)}

$10 / 06 / 71$
$07 / 27 / 66$
$03 / 08 / 66$
$08 / 26 / 65$
$10 / 21 / 64$
$03 / 18 / 71$
$06 / 04 / 64$
$03 / 25 / 71$
$03 / 22 / 71$
$04 / 11 / 69$
$03 / 29 / 71$
$04 / 16 / 69$
$03 / 23 / 71$
$03 / 21 / 71$
$03 / 21 / 71$

2066 - 4500

2446-4500

2600

2506-7207

1740-5690

INT

INT

IN T

INT

INT

INT

INT

INT

INT

INT

INT

INT

INT

INT

INT

INT

INT

INT

INT

INT

INT

INT

INT

INT

INT

INT

INT

INT

$06 / 02 / 71$

$09 / 21 / 71$

$09 / 21 / 7$

$08 / 03 / 72$

$08 / 03 / 72$

$11 / 14 / 72$

$09 / 22 / 71$

$09 / 22 / 71$

$09 / 22 / 71$

$09 / 22 / 71$

$02 / 15 / 73$

$02 / 01 / 73$

$08 / 22 / 73$

$03 / 19 / 73$

$11 / 16 / 72$

$09 / 24 / 74$

$T$
$T$
$T$
$T$
$T$
C
OAL
OAL
OAL
C
$C$
OAL
QAL
$T / C$
$T / C$
$T$
$T$
$T$
$T$
$T$
$T$
$T$
$Y$
$T$
$T$
$T$
$T$
$T$
$T$
$T$
$T$
$T$
$T$
$T$
$T$
$T$
$T$
$T$
$T$
$T$
$T$
$T$
$T$
$T$
$T$
$T$
$T$
$T$
$T$
$T$
$T$
$T$
$T$
$T$
$T$
$T$


SITE

17, U 12E.07

18, U12E.04

19. U12E

20, U12E

22. U12E.03

23. U12E

24. U12E. 02

25. U12E. 05

26, U12E.O3

27. U12E.03

28. U12E.O3

30. $1112 E$

31. U12E

32, U12E

33. U12E

34, U12B

35. U128.03

36, U 12.04

SEEP 2: U12N.O3

SEEP 2. U12N.O3

SEEP 4, U12N.O3

LYSIMETER 1, U I2N.O5

LYSIMETER 1, U I2N.05
LYSIMETER 2: U12N.05

LYSIMETER 3, U12N.05

LYSIMETER 4, U12N.O5

LYSIMETER 5, U12N.05

LYSIMETER 6, SURF SOIL

LYSIMETER 7, SURF SOIL

LYSIMETER 9, SURF SOIL

ANAL 2589. TUNNEL U12B. E

ANAL 2819. TUNNEL U12B. D

ANAL 2913. TUNNEL U12E,

ANAL 3260, TUNNEL U12E, D

ANAL 3541, TUNNEL U12E,
LOCATION

DATE

INT

(M)

$R M / F W$
$R M / F W$

$\mathrm{RM} / \mathrm{FW}$
$\mathrm{RM} / \mathrm{FW}$

RM/FW
RM/FW

RM/FW

$R M / F W$

$\mathrm{RM} / \mathrm{FW}$

$\mathrm{RM} / \mathrm{FW}$

$R M / F W$

RM/FW

$R M / F W$
$R M / F W$

$R M / F W$

RM/FW

$R M / F W$

$R M / F W$

$R M / F W$

RM/FW

$R M / F W$
$R M / F W$

RM/FW

$R M / F W$

RM

RM

RM

RM

RM
RM
RM

$R M$

RM

RM

RM

RM

RM

RM

RM

RM

RM

RM

RM

$03 / 11 / 60$

$06 / 02 / 59$

$11 / 22 / 59$

$11 / 29 / 59$

$01 / 0 \% / 60$

$12 / 14 / 59$

$01 / 29 / 59$

$10 / 11 / 58$

$09 / 12 / 58$

$05 / 27 / 59$

$05 / 20 / 59$

$12 / 03 / 59$

$03 / 18 / 66$

$01 / 22 / 59$

$06 / 24 / 59$

$07 / 18 / 59$

$07 / 21 / 59$

$06 / 06 / 58$

$08 / 22 / 58$

$09 / 29 / 58$

AVERAGE

AVERAGE

AVERAGE

AVERAGE

AVERAGE

AVERAGE

AVERAGE

AVERAGE

AVERAGE

AVERAGE

AVERAGE

AVERAGE

$08 / 22 / 58$

$06 / 06 / 58$

$10 / 11 / 58$

$06 / 02 / 59$

$11 / 22 / 59$

IN

INT

INT

IN

INT

INT

INT

INT

INT

INT
INT
INT

INT

INT

INT

INT

INT

INT

INT

INT

INT

INT

INT

INT

INT

INT

INT

INT

INT

INT

INT

INT

INT

INT

LI THOLOGY 
点总

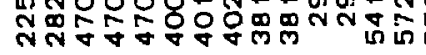

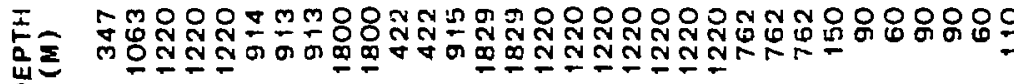

点至

岌

$\frac{n}{n}$

㟔焉

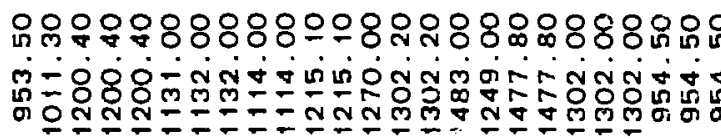
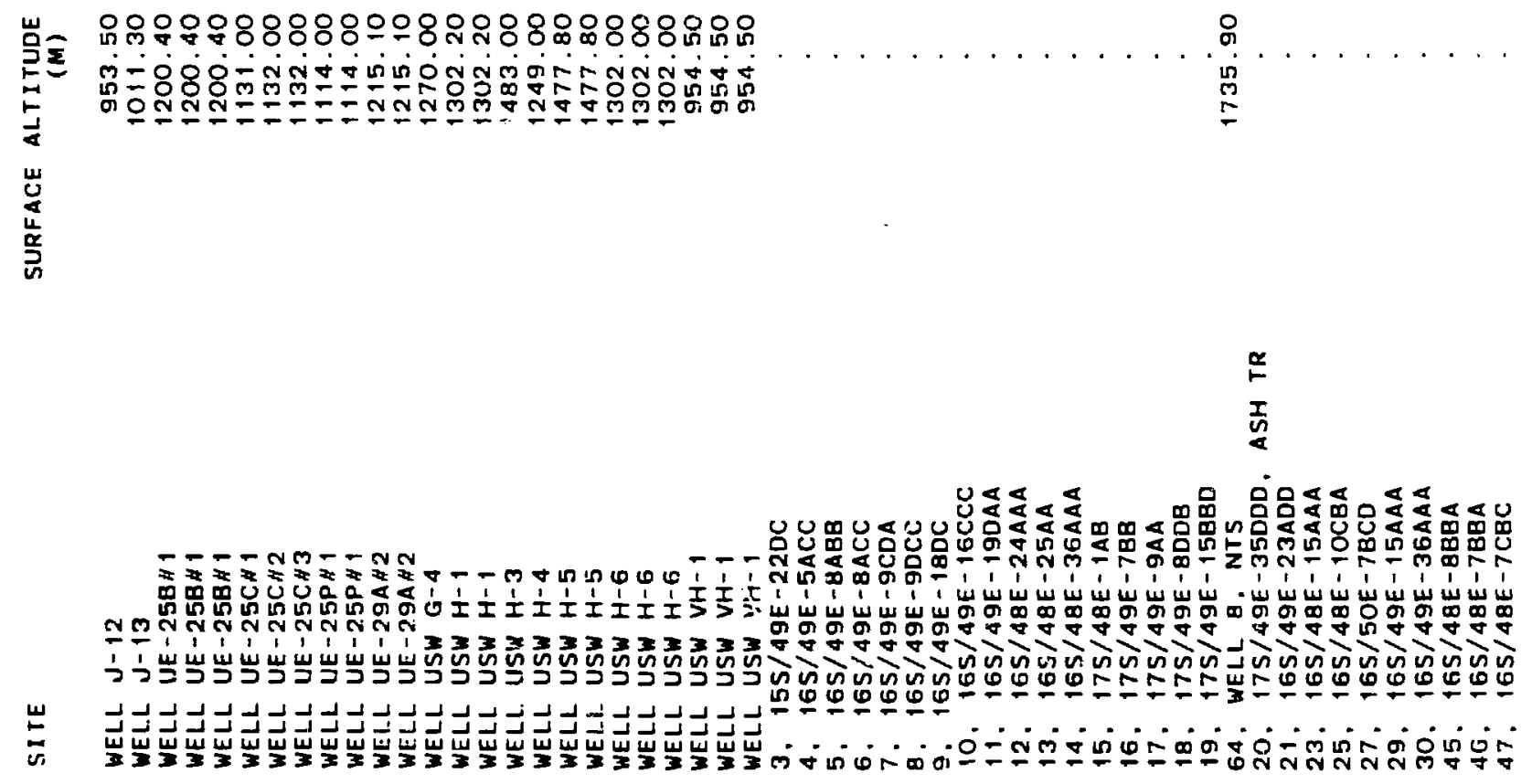


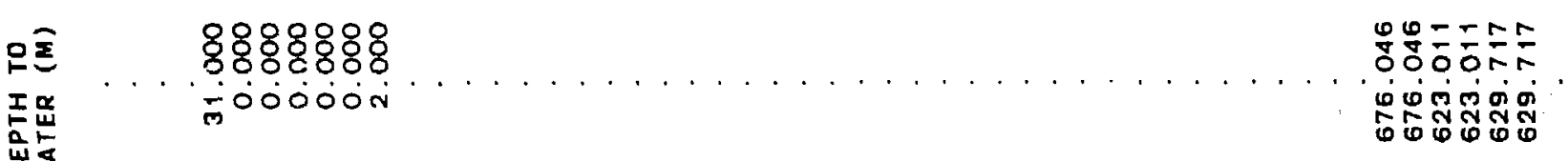

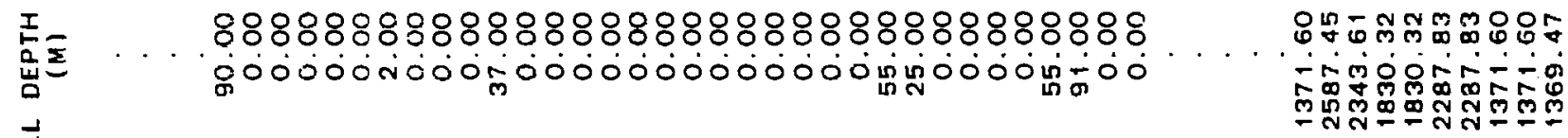

点

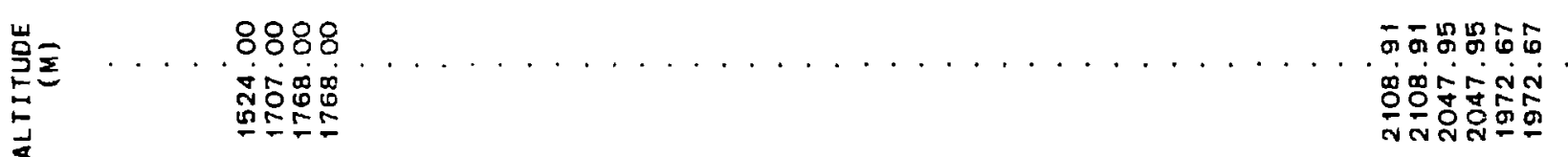

崖

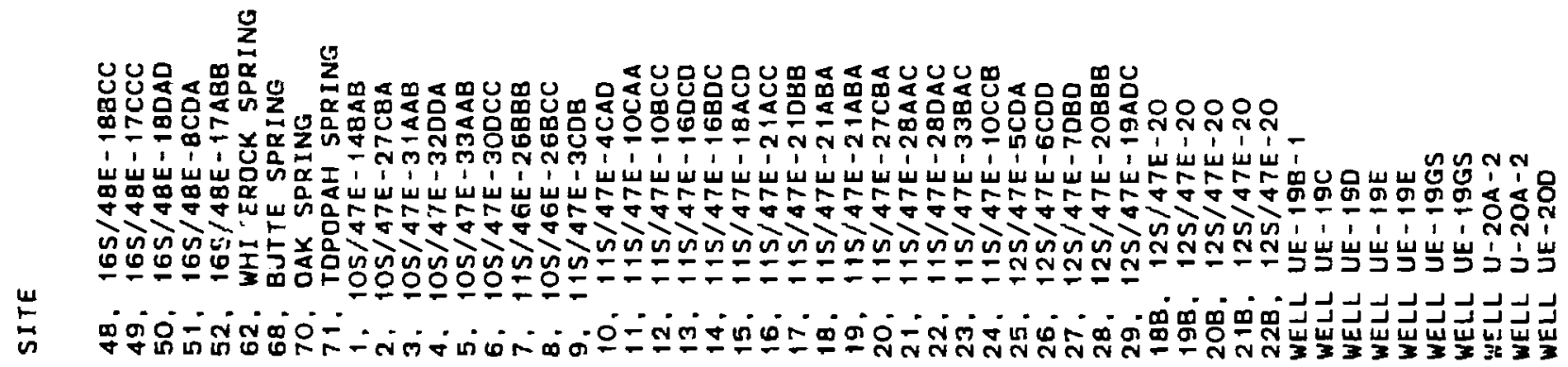


TEMP

WELL UE - 2OE- 1

WELL UE $-2 \mathrm{OH}$

WELL UE-2OJ

WELL AI:MY - I

1949.20

2196.69

1734.31

593.00

277.00

274.00

366 . 00

519.00

LL 5B

WELL 5C

WELL $C$

WELL $C-1$
WELL 3

WELL 3

WELL A

WELL 2

503.00

548.00

570.20

1043.00

1043.00

1810.00
134.40

169.60

199.20

202.40

257.60

260.00

260.00

441.40

442.40

291.40

320.30

320.60

321.30

350.80

411.20

411.20

470.60

472.40

501.70

503.20

532.80

0.00

$\begin{array}{rr}. & 32.8000 \\ . & 32.2000 \\ 240 & 38.9000 \\ 212 & 31.0000 \\ 209 & 23.0000 \\ 210 & 25.0000 \\ 470 & 24.5000 \\ 470 & 37.0000 \\ 486 & 38.0000 \\ 492 & 21.5000 \\ 626 & 26.5000 \\ 203 & 34.5000 \\ & 34.5000\end{array}$

(3). $411.2(M)$

(1) $472.4(M)$

UE 12T $13-22$, 503 2 (M)

UE 1 $2 T H 3-23,532, B(M)$

RML TA. SURFACE

RML 1B, SURFACE

2. U12N.05

3. UI2N.05

4. U12N MAIN

5. U12N.07 BYPASS

6. U12N.O2

7. U12T.02 BYPASS

B. U12T.02

9. U12T.02 EYPASS

10. U12T MAIN

1i. U12T.03

12. U12T.03

14. U12T.O3

15. U12T.03

17. U12E. 07

18. U12E.04

19. U12E 
20. U12E

21. U12E. O4

22. U12E. O3

23. U12E

24. U12E.02

25. U12E. 05

26. U12E.03

27. U१2E.03

28. U U2E.03

29, U12E. O7

30. U12E

31, U12E

32. U12E

33. U12E

34, U12B

35. U12B.03

36. U12.04

SEEP 1, U12T

SEEP 2, U12N.03

SEEP 3. U12N. OS

SEEF 4, U12N.03

LYSIMETER U U12N.05

LYSIMETER 2, U12N.05

LYSIMETER 3, U12N.O5

LYSIMETER 4. U12N.05

LYSIMETER 5, U12N.05

LYSIHETER 6, SURF SOIL

LYSIMETER 7, SURF SOIL

LYSIMETER 9， SURF SOIL

ANAL 2539. TUNAEL U12B.

ANAL 2819, TUNNEL U128, D

ANAL 2913. TUNNEL U12E, D

ANAL 3260. TUNNEL U12E, D

ANAL 3541. TUNNEL U12E, M
SURFACE ALTITUDE

(M)

HLLL DEPTH

(M)

HATER (M)
14:49 THURSDAY, MAY 29, i986 12

TMP

(C)
13.1000
15.8000
16.6000
20.5000
14.1000
13.1000
15.5000
16.4000
18.7000
13.5000
9.3000
14.7000
.
18.0000
16.0000 


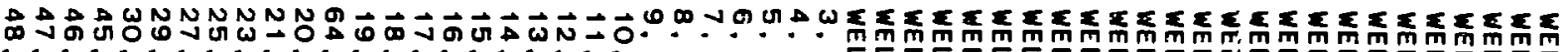

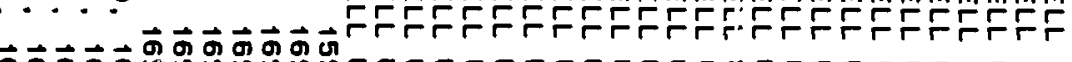

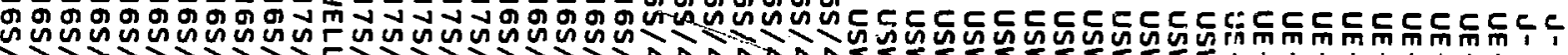

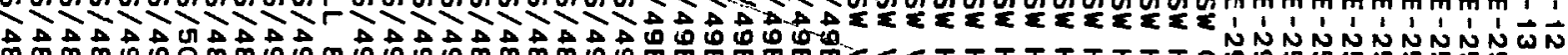

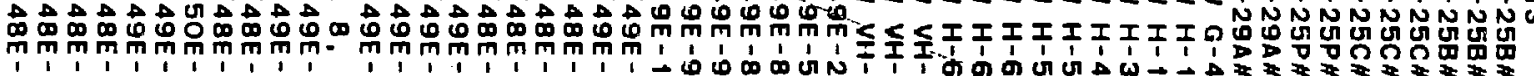

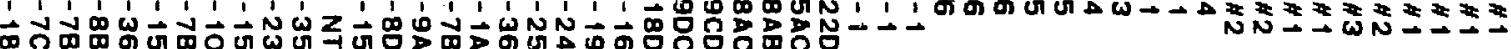

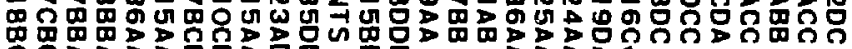
ती॰

点

$\cong$ $\vec{m}$

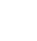


1. 50000

o. 10000

0.52000

0.45000

D. 18000

0.18000

0.55000

0.58000

0.75000

0.75000

0.60000

0.00000

o. 15000

0.40000

0.65000

0.35000

0.35000

0.45000

0.42000

0.55000

0.58000

0.62000

.32000

0.010000

c. 100000

o. 200000

0.040000

0.010000

0.060000

O. 180000

190000

0.190000

0.010000

0.040000

0.040000

0. 180500

0.020000

0.020000

0.020000

0.150000

0.120000

o. 130000

0.130000

0.210000

0.190000

0.90000

0.25000

0.21000

0.30000

0.32000

.80000

0.68000

0.63000

0.68000

0.95000

0.000000

0.030000

0.110000

0.110000

O. 180000

0. 130000

0. 150000

0.150000

0.230000

0.59880

0.32435

1.42216

0.09232

0.00998

0.06986

0.87325

O. 15220

o. 14721

0.10729

0.00499

0.098745
0.001114
0.0115203
0.002057
0.004114
0.002057
0.008229
0.004114
0.008229
0.004114
0.002057
0.002057

0.310000

0.270000

O. 260000

0. 310000

0.200000

0.150000
0.160000

o. 160000

0.210000

0.220000

o. 200000

C. 000000

0.230000

0.010000

0.040000

o. 120000

0.220000

0.180000

O. 200000

0.190000

0. 090000

o. 220000

0.210000

0.200000

0. 280000

0.230000

0.060000

o. 120000

o. 150000

O. 190000

4.8700

4. 6100

4.5700

11. 1400

O. 260000

0. 260000

$\begin{array}{ll}11.0500 & 0.260000 \\ 12.6200 & 0.260000\end{array}$

0.01497

1.8269
6.1332
6.6551
1.8704
1.6529
3.6538
2.9578
2.3924
2.3924
3.8278
3.6103
2.7838

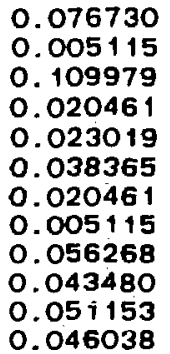




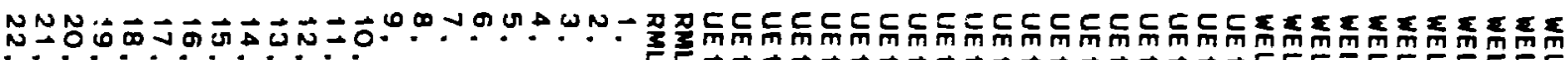

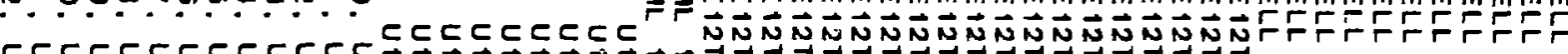

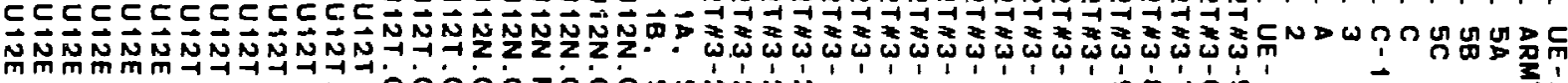

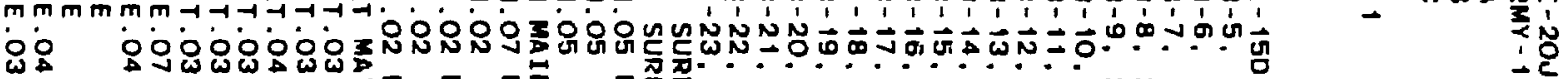

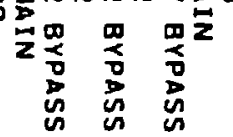

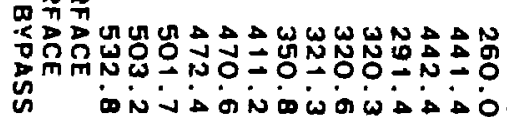

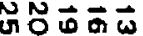

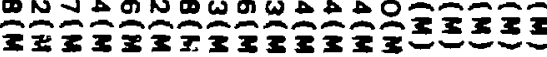

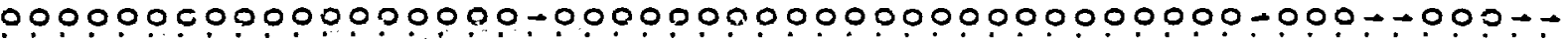
\%웅 $80 \% 8 \%$

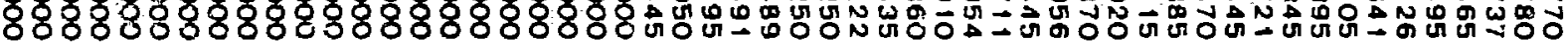

$00000000000000000000000000000000000000000000000-000000$

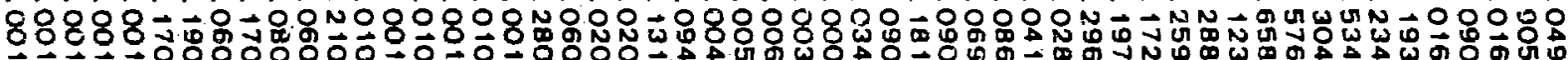

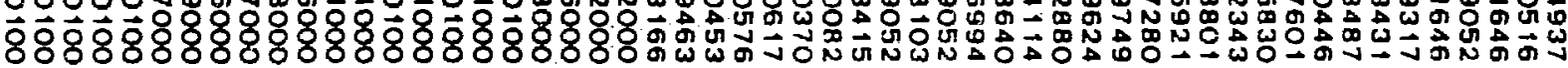

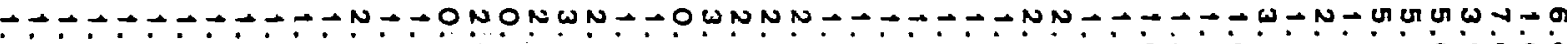
wN

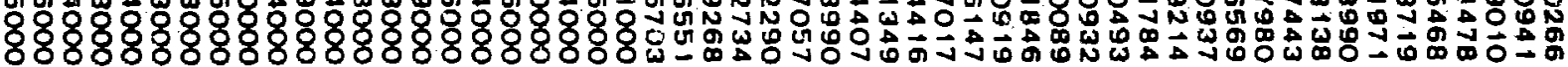

000000000000000000000000000000000000000000000000000000

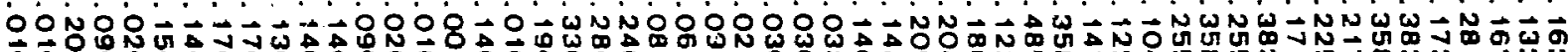

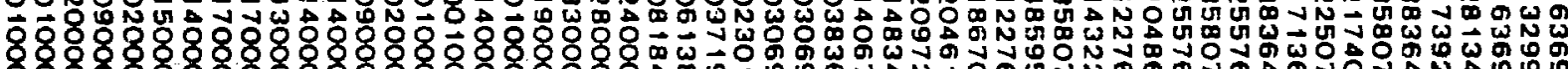

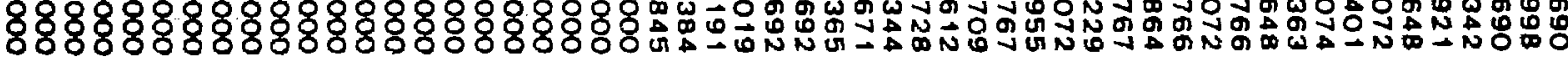


SAS

SITE

23. U12E

24. U12E.02

25. U12E. 05

26. U12E.03

27. U12E.03

28. U12E.03

30 . U12E

31. U12E

32. U12E

33. U12E

34. U12B

35, U12B.03

36 , U12.04

SEEP 1. U12T

SEEP 2, U12N.O3

SEEP 3. U12N. O5

SEEP 4, U

LYSIMETER 1, U13N. 05

LYSIMETER 2, U12N.05

LYSINATER 3, U12N.05

LYSIME TER 4, U12N.05

LYSIMETER 5, U12N.05

LYSIMETER 6. SURF SOIL

LYSIMETER 7, SURF SOIL

LYSIMETER 9, SURF SOIL

ANAL 2589, TUNNEL U12B, E

ANAL 2819, TUNNEL U12B, D

ANAL 2913. TUNNEL UT2E. D

ANAL 3260, TUNNEL U12E, D

$N=193$
CA

0.200000

0.001000

0.060000

0.060000

0.020000

0.040000

0.430000

0.330000

0.100000

0.400000

0.080000

0.320000

0.240000

0.200000

0.037176

0.069611

0.225549

0.018713

0.983034

0.104291

0.146457

O. 103543

0.004990

0.441617

0.24451 it

0.763473

0.324351

0.239521

0.059880

0.004990

0.059880
MG

0.080000

0.001000

0.001000

0.001000

0.001000

0.001000

o. 120000

0.001000

0.001000

0.040000

0.001000

0.040000

0.060000

0. 340000

0.005349

0.006583

0.004937

0.046081

0.005760

0.004937

0.004937

0.004937

0.158404

0.098745

0.259617

0.078173

0.061716

0.000041

0.000041
0.000041
14:49 THURSDAY. MAY 29, 198616

0.170000

0.060000

0.080000

0.030000

0.040000

0.070000

0.150000

0.160000

0.280000

0.200000

0.070000

0.070000

0.070000

0.080000

0.092076

0.089518

C. 181594

0.066499

O. 117652

0.173921

0.156017

0.014834

0.023530

0.027111

o. 112537

0.071614

0.071614

0.056268

0.015346 


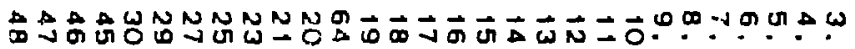

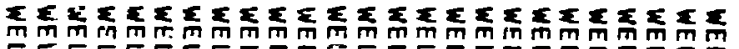

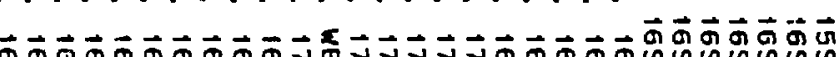

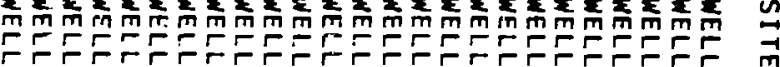

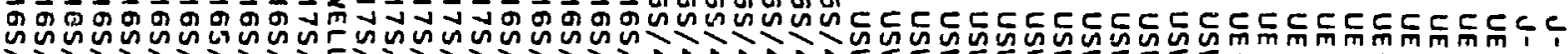

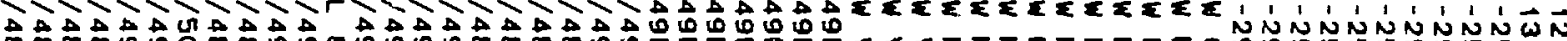

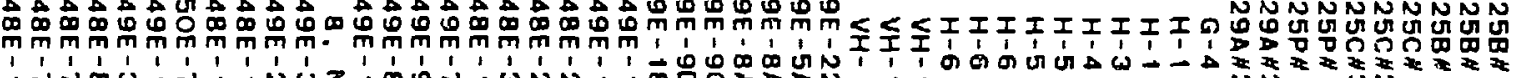

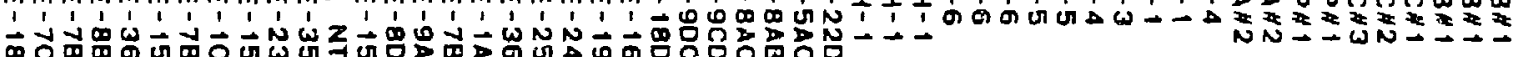

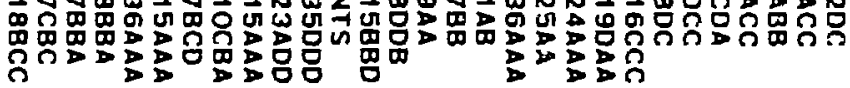

耑

--". - 00000000000000000000000000000000000000000000000000 NהN丶万人

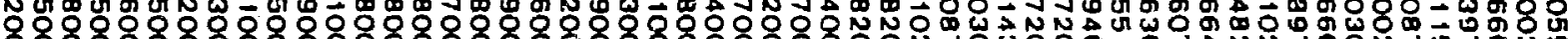

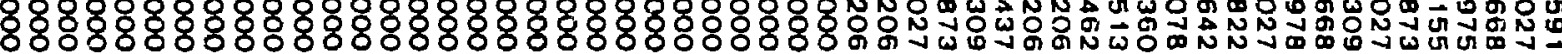

- - N-1.00000000000000000000000000000000000000000000000

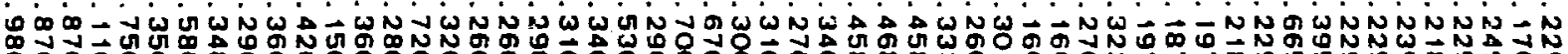

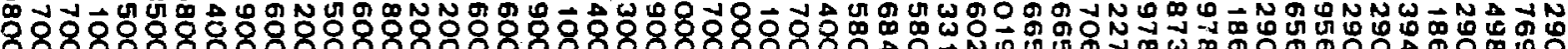

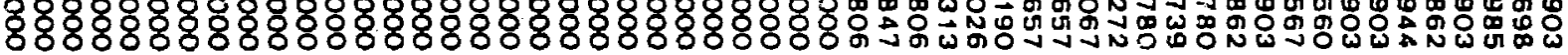

$0000---0-7-0-1-7-0-00-00000000000000000000000000$

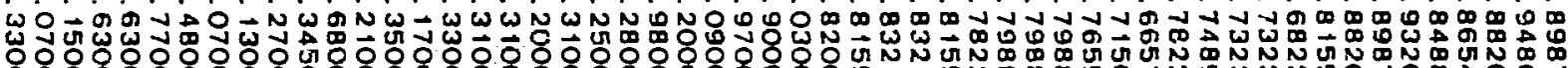

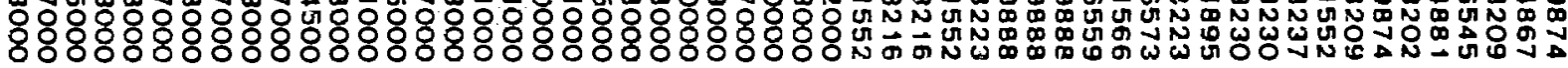

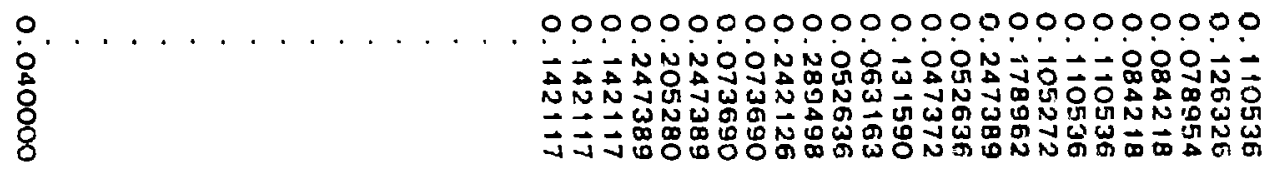




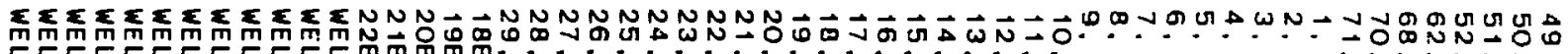

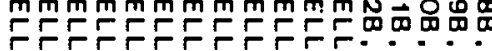

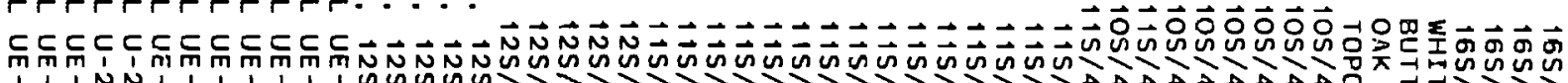
ÚN

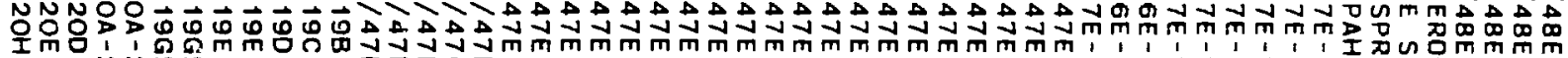
1

- 1

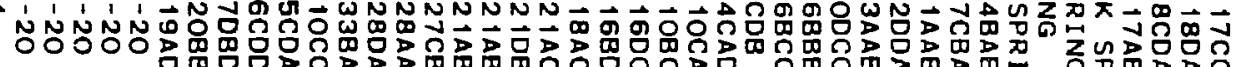

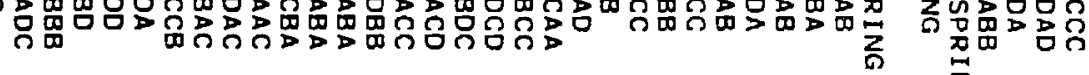
苗

000000000000

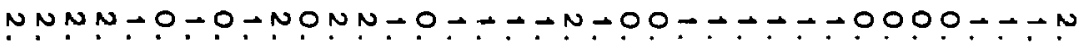
जी जin

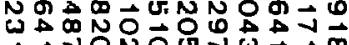
Oे

000000000000 w

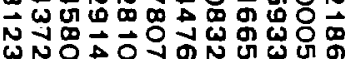

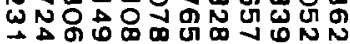

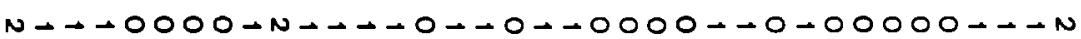
के $\omega$ \%

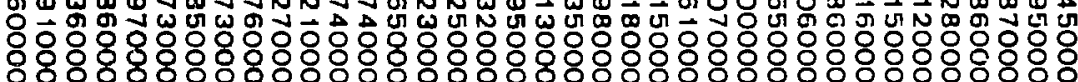

$00,0000-0,000$ i ن

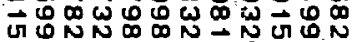

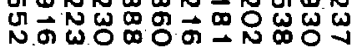

승

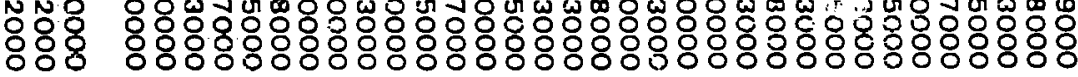

$\stackrel{n}{\mathrm{~N}}$

$\pi$ $\omega \omega \omega \omega$
$\omega$
$\omega$ 00000000000000000000000000000

000000000000

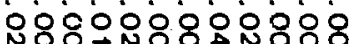

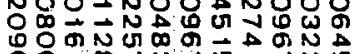

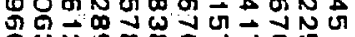

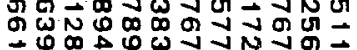

- N $\rightarrow-O \rightarrow O N N N-$ N

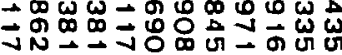




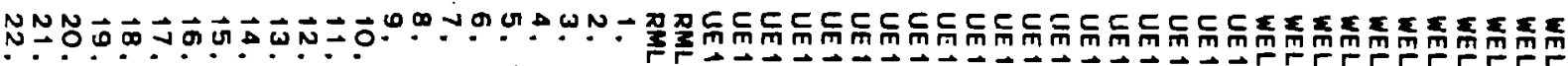
.

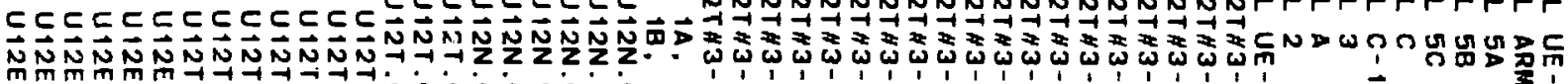

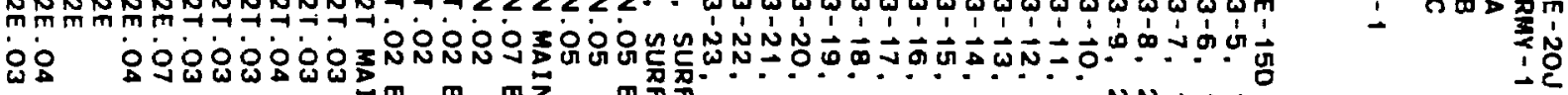

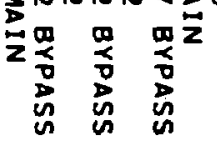$$
\text { 空妿 }
$$

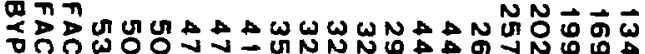

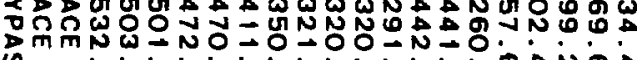

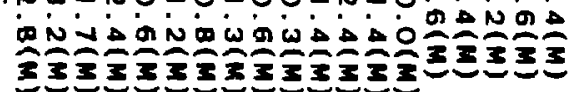

$0000000000000000000000000000000000000-7000000000000000$

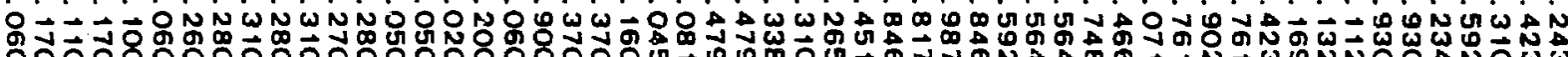

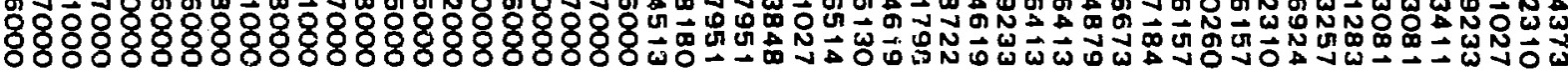

0.000.00000000000000000000000000.

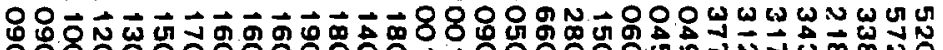
ठ8ठ
$0,000000000000000000 \%$

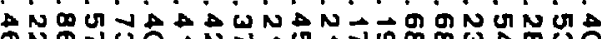
ه

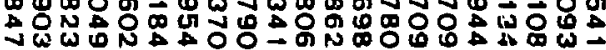




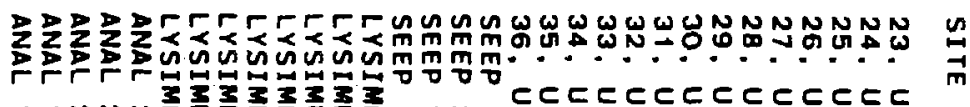

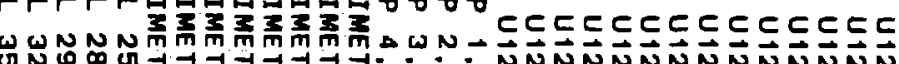

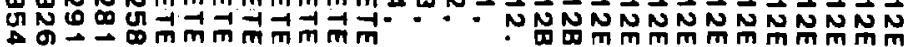

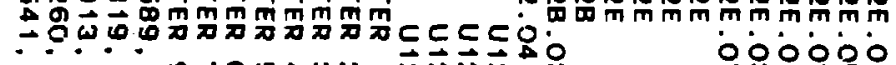

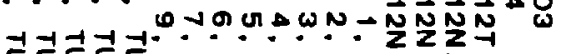

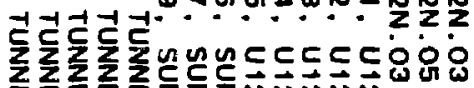

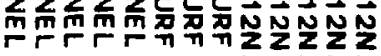

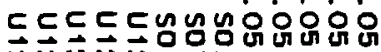

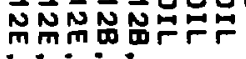

so00m

0000000.000000000000000000000000

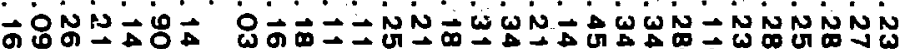

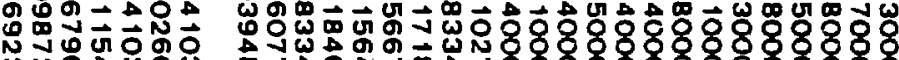

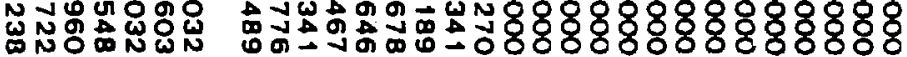

0000000. 000000000. 0000000000000

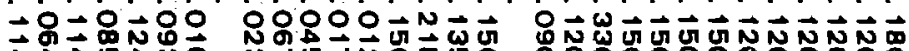
ज代出需

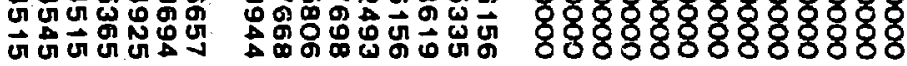

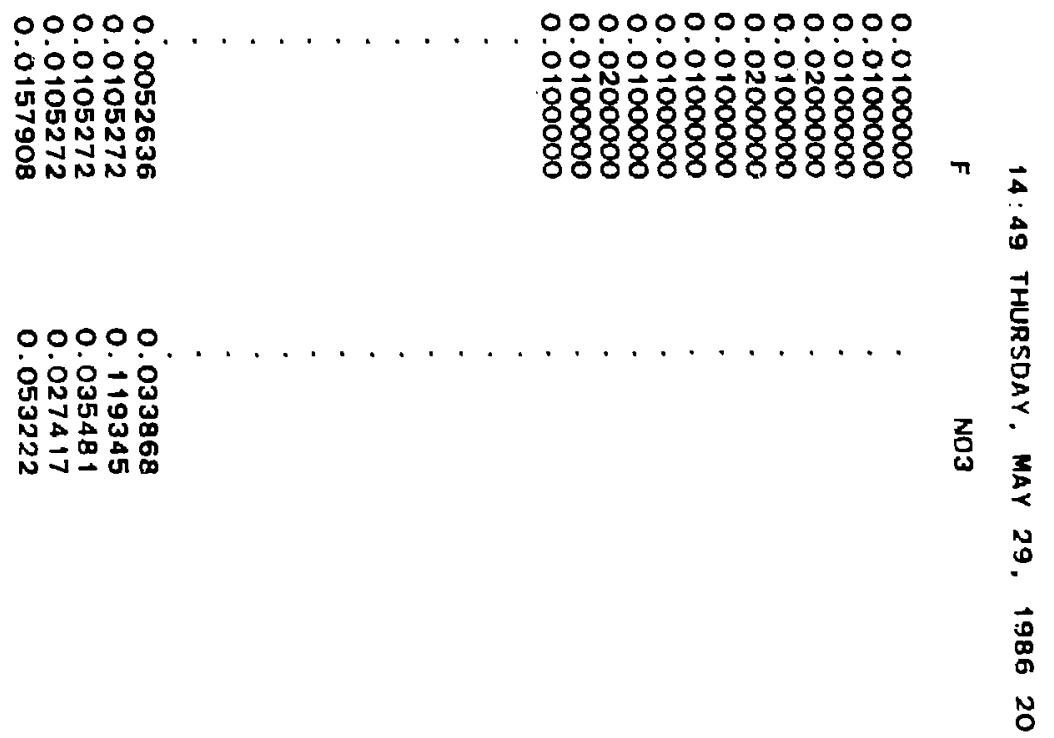




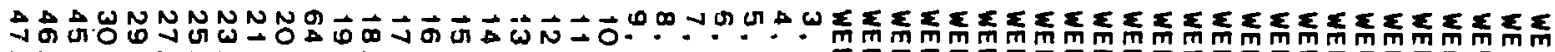
-

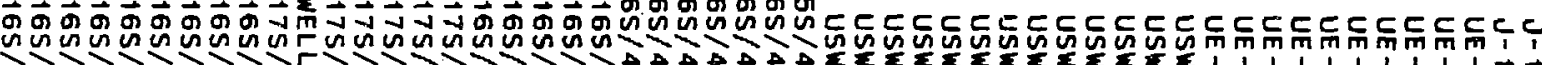

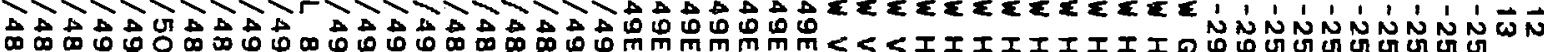

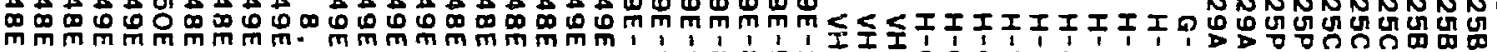

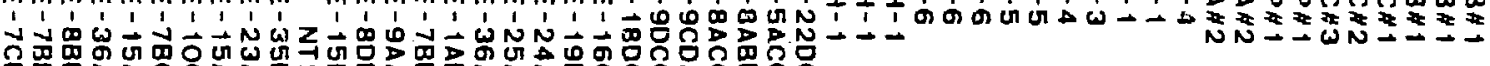

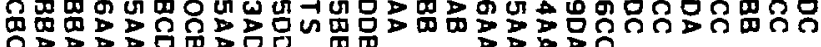

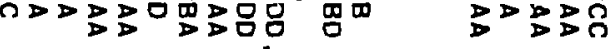

$$
\text { 品 }
$$

W 并

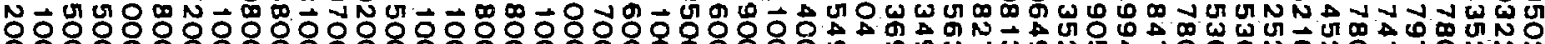

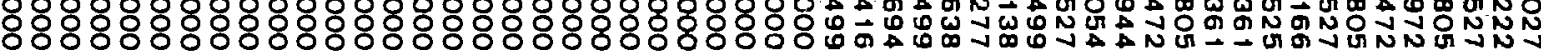

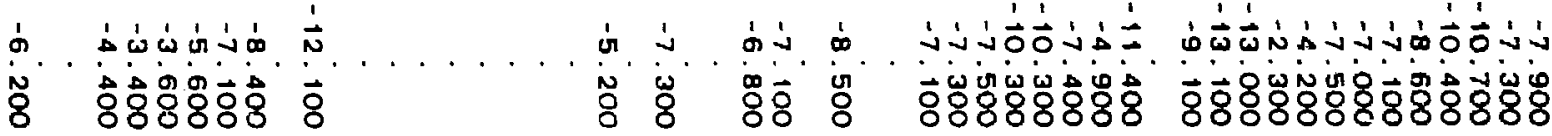




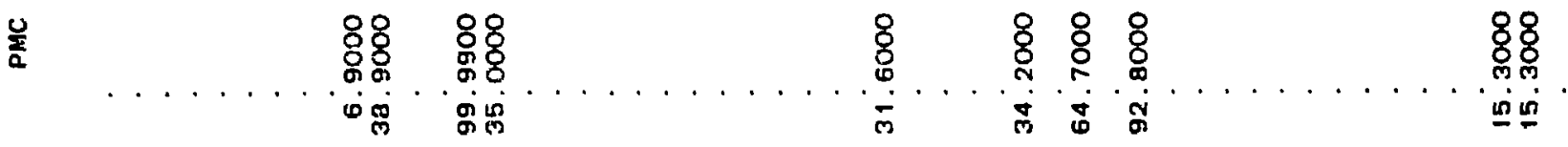

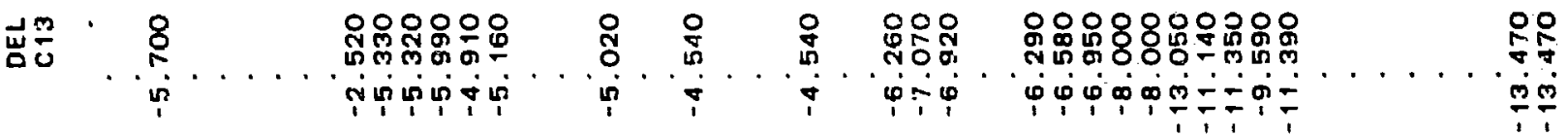

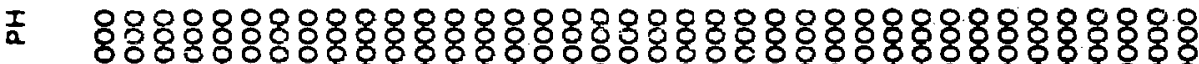

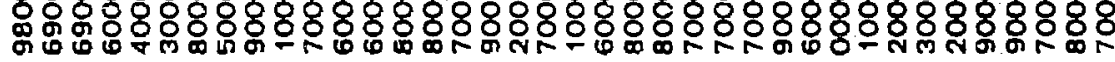

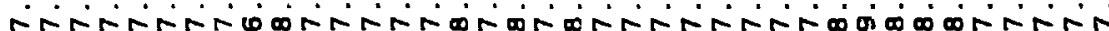

$\frac{n}{\operatorname{sn}}$

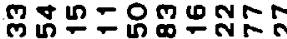

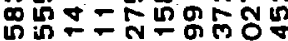

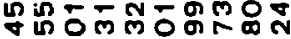
- mm

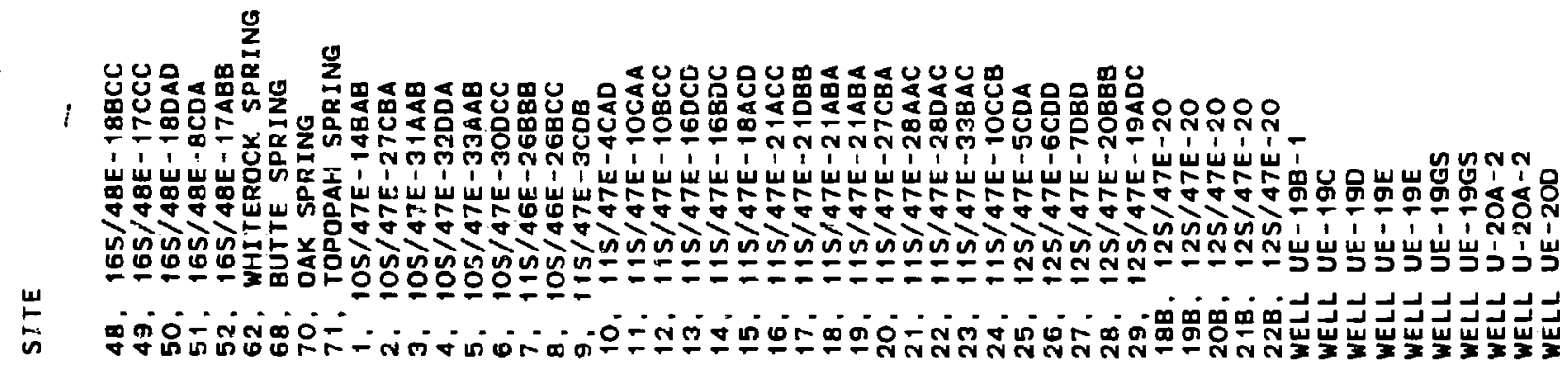




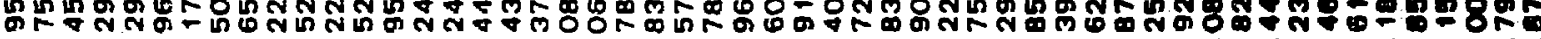
$\because-$ -

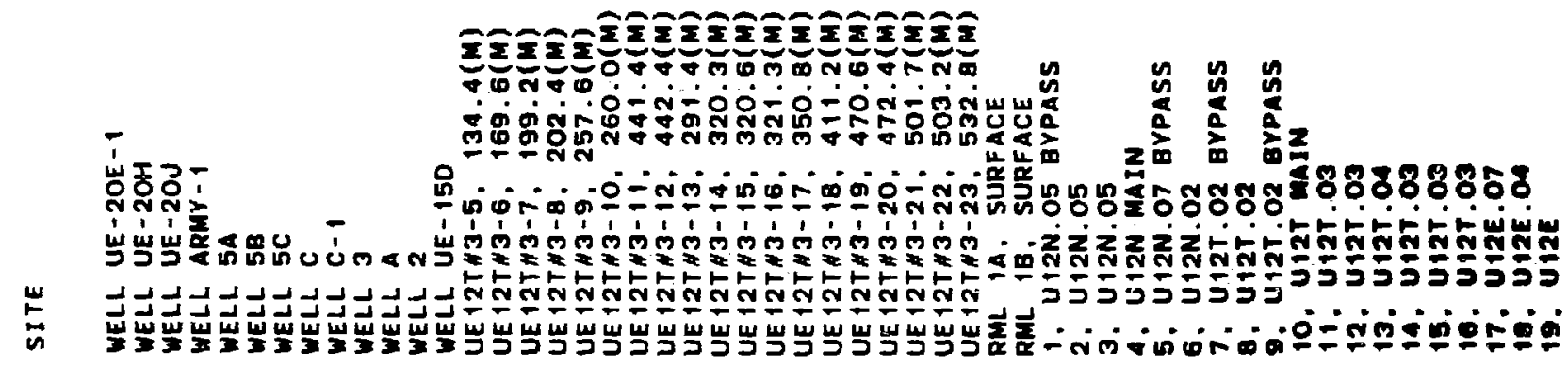


SAS

$\mathrm{HCO}$

PH

0.9300

20. U12E.

21, U12E.OA

22. U12E.O3

24. U12E. 02

25. U12E. 05

26. U12E. O3

27. U12E. O3

28, U12E.03

28, U12E.07

30, U12E

31. U12E

32. U12E

33. U12E

34. U12B.

35. U12B.03

SEEP 1. U12T

SEEP 2, U12N.03

SEEP 3, U12N.05

SEEP 4, U12N.O3

LYSIMETER 1, U12N. O5

LYSIMETER 2, U12N.O5

LYSIMETER 3, U12N.05

LYSIMETER 3, U12N.05

LYSIMETER 4, U12N.O5

LYSIMETER 5, U12N.05

LYSIMETER 6, SURF SOIL

LYSIMETEF 7, SURF SOIL

ANAL 2589 TUNNEL U12B, E

ANAL 2819 , TUNNEL U12B, D

ANAL 2913. TUNNEL UI2E. D

ANAL 3260. TUNNEL U12E, D

ANAL 3541. TUNNEL U12E, M

$N=193$

\begin{tabular}{rr}
0.9300 & 7.00000 \\
0.8800 & 6.90000 \\
1.1500 & 7.10000 \\
0.9200 & 7.80000 \\
0.9800 & 7.40000 \\
1.0500 & 7.40000 \\
1.3400 & 7.50000 \\
1.3400 & 6.00000 \\
1.3800 & 7.50000 \\
2.0000 & 7.40000 \\
1.6100 & 8.00000 \\
1.7700 & 6.80000 \\
2.0000 & 7.90000 \\
2.1000 & 7.00000 \\
1.2100 & 7.60000 \\
0.7900 & 6.90000 \\
0.9800 & 7.50000 \\
2.4747 & 7.90000 \\
1.8192 & 6.80000 \\
2.6878 & 6.80000 \\
1.7536 & 7.20000 \\
10.7347 & 6.60000 \\
2.7205 & 6.80000 \\
3.1794 & 6.80000 \\
2.7205 & 6.80000 \\
0.9047 & 7.10000 \\
1.7208 &. \\
1.7208 & 7.10000 \\
3.0483 & 7.30000 \\
1.2128 & 7.60000 \\
0.7867 & 7.60000 \\
0.9833 & 7.40000 \\
0.7867 & 7.30000 \\
0.8686 & 7.60000 \\
& \\
\hline
\end{tabular}

14:49 THURSDAY, MAY 29,198624

PMC 


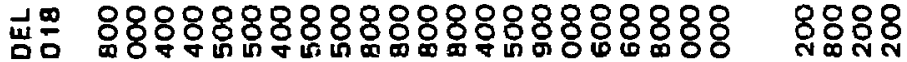

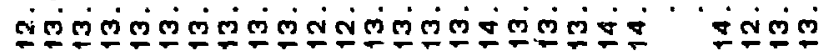

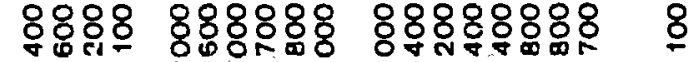

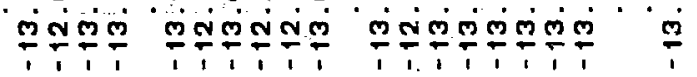

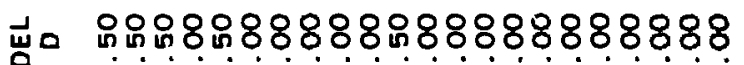

ถู ติ่
$888 \%$

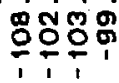

8808888888.88888888

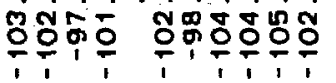

$\stackrel{0}{\stackrel{2}{1}}$

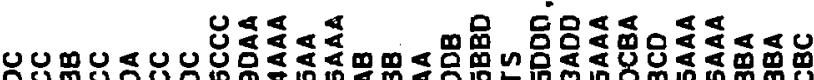

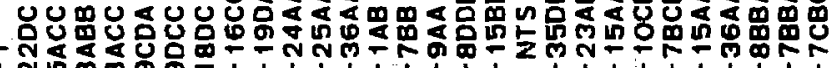

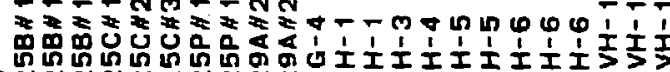

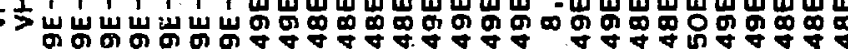

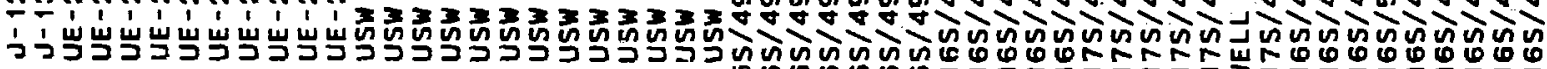

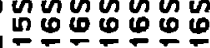

） 


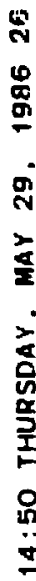

$\frac{5}{0}$

ช

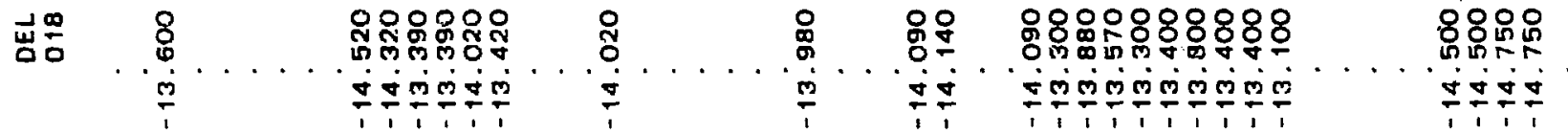

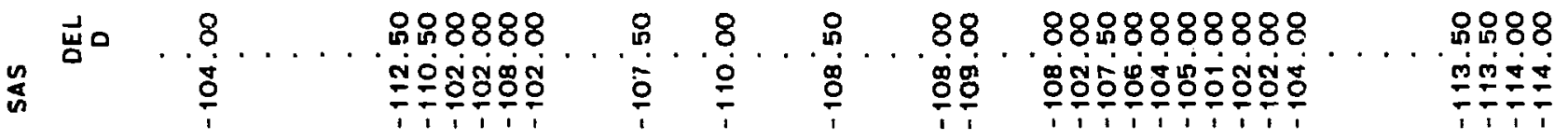

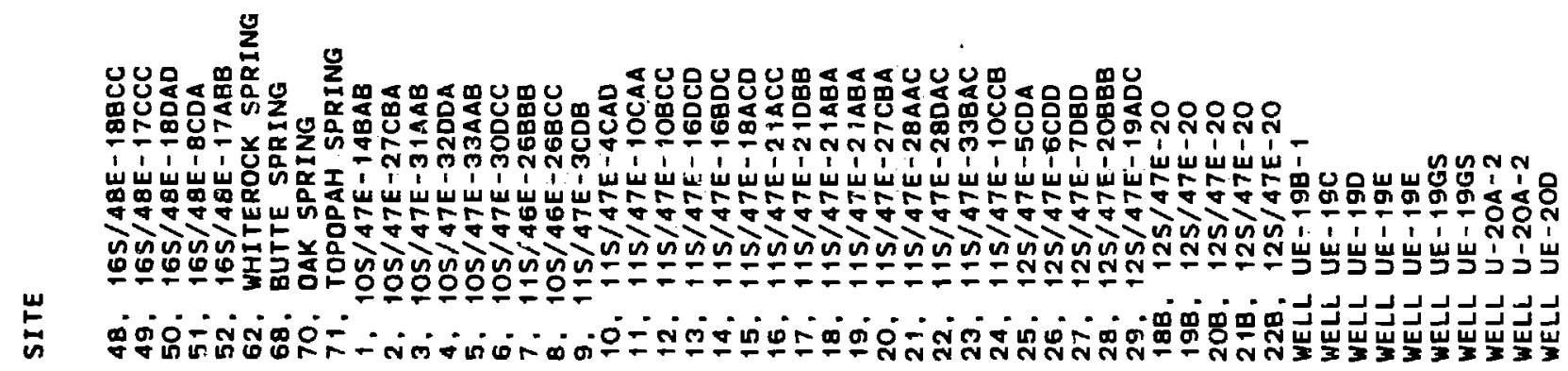


SITE

20. U12E

21. U12E.O4

22, U12E.03

23. UY2E

24. U12E.02

25, U12E.05

26. U12E.03

27. U12E.03

28, U12E.03

29, U12E.

31 U12E

$32, U 12 E$

33, I12E

33. J12E

35, U12B.03

36. U12.04

36. U 12.04

SEEP 1, U12T

SEEP 2, U12N.03

SEEP 3, U12N.O5

SEEP 4, U12N.03

LYSIMETER 1. U12N. OS

LYSIMETER 2, U12N.CS

LYSIMETER 3, U12N.O5

LYSIMETER 4, U12N.05

LYSIMETER 5, U12N.05

LYSIMETER 6, SURF SCIL

LYSIMETER 7, SURF SOIL

LYSIMETER 9;" SURF SOIL

ANAL 2589, TUNNEL U12B.

ANAL 2819. TUNNEL U 12B. D

ANAL 2913, TUNNEL U12E, D

ANAL 3260. TUNNEL U12E. D

ANAL 3541, TUNNEL U12E, M

$N=\quad 193$
DEL

DEL

O2 $(M G / L)$

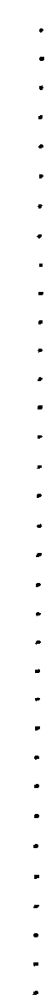




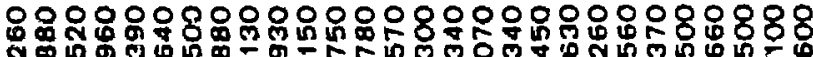

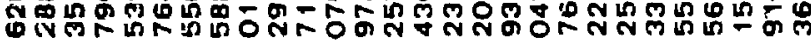

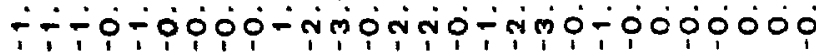

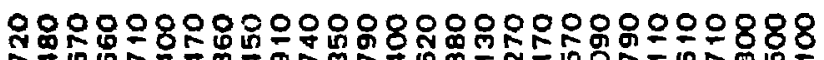

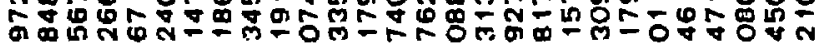
888888888

冼

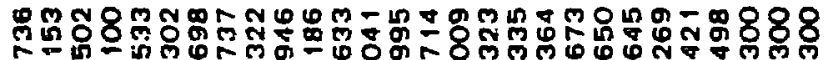

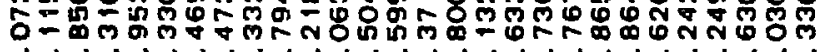
ن

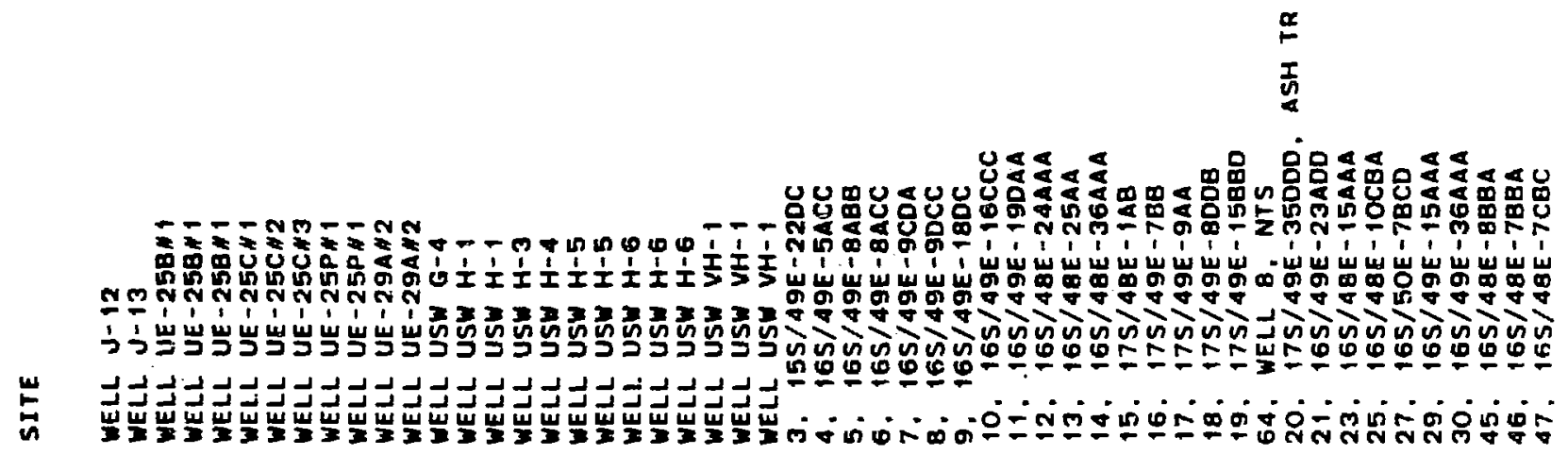




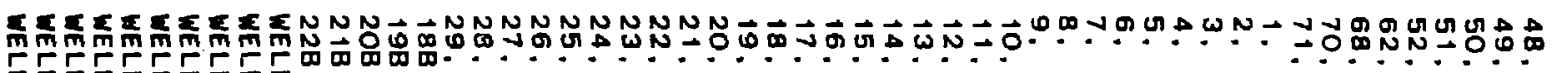
FFFFFFFFFF.

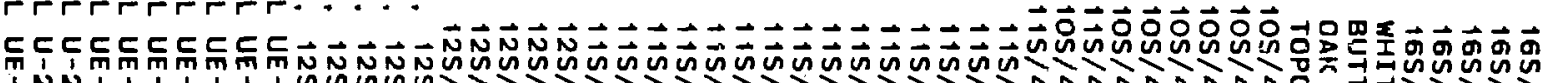

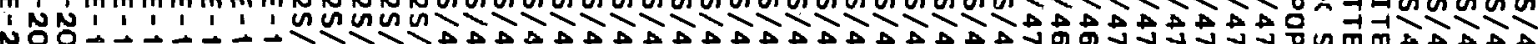
NO음 $\overrightarrow{0} \overrightarrow{0} \overrightarrow{0} \overrightarrow{0} \dot{0}$

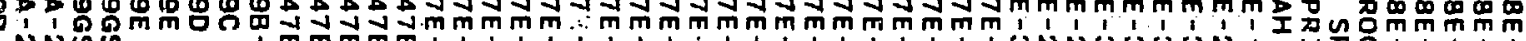
-

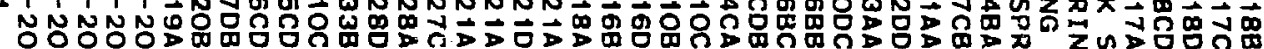

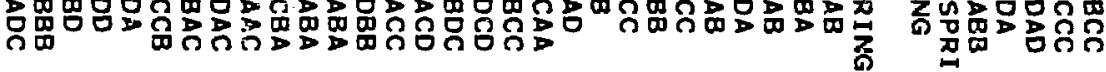
点

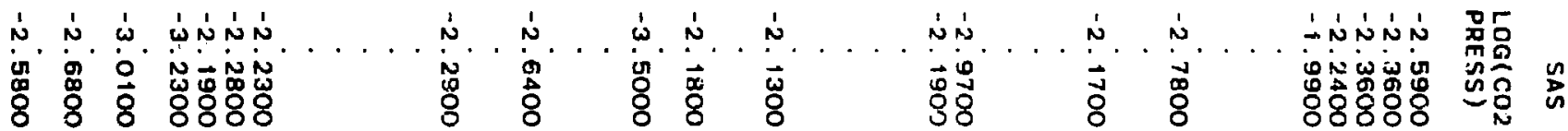

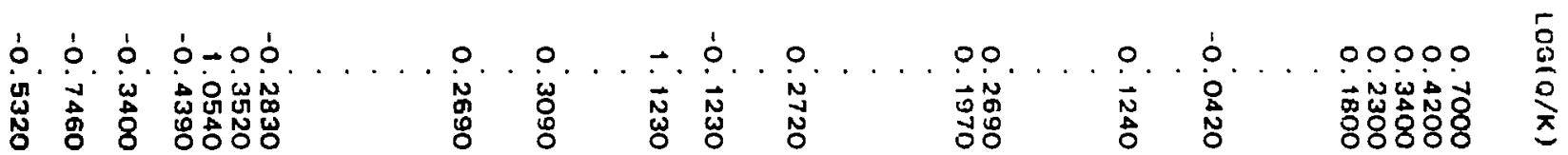

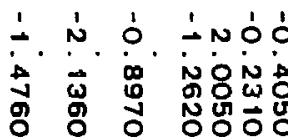

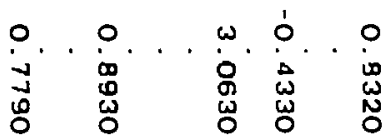

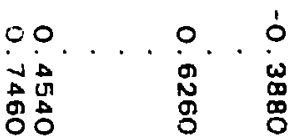

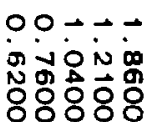

두음 
LOG(CO2
PRESS)

CALCITE $\operatorname{LOG}(0 / K)$

-3.3800
-3.0300

WELL UE-2OE-1

WELL UE-2OH

WELL UE-2OJ

WELL ARMY-1

WELL SA

WELL 5B

WELL 5C

WELL $C$

WELL C-1

WELL 3

WELL 2

WELL UE-15D

UE 12TH3-5, $134.4(M)$

UE 12TA3-6, $169.6(\mathrm{M})$

UE 12TH3-7. 199.2(M)

UE 12TH3-8, 202.4(M)

UE $12 T \# 3-9,257.6(M)$

UE $12 T H 3-10,260.0(\mathrm{M})$

UE 12TH3-11, 441.4(M)

UE 12TH3-12, 442.4(M)

UE $12 T H 3-14 ; 320.3(M)$

UE $12 T k 3-15,320.6(\mathrm{M})$

UE $12 T H 3-16,321.3(M)$

UE 12TH3-16. 321.3(M)

UE 12TH3-17, 350.B(M)

UE 12TH3-18, 411.2(M)

UE $12 T H 3-20,472.4(M)$

UE 12TH3-21; 501.7 (M)

UE 12TH3-22. 503.2(M)

RML TA, SURFACE

RML 1B. SURFACE

1. UI2N. O5 BYPASS

2. U12N.05

2. U12N.05

4. U12N MAIN

5, U12N.07 BYPASS

6. U12N.O2

7. U12T.O2 BYPASS

B. U12T.02

9. U12T.02 BYPASS

10, U12T MAIN

11. U12T.03

12. U12T.O3

13. U 12T.O4

14. U12T.O3

15. U12T.03

16. U12T.03

17. U12E. 07

18. U12E.
$-1.8200$

$-2.5730$

$-2.6480$

$-2.6600$

$-2.6190$

$-1.7980$

$-2.4510$

$-2.4780$

$-2.4680$

$-2.2750$

$-2.8500$

$-2.5900$

$-2.5900$

-3. 1900

$-2.8300$

-3. 1700

$-2.8000$

$-3.1300$

$-3.0100$

- 3.0100

$-3.2700$

$-3.1800$

$-3.1400$

$-3.2400$

$-3.1600$

$-2.9700$

$-3.0800$

$-3.0600$

$-2.9400$

$-2.9300$

$-2.8800$

$-2.8600$

$-2.3800$

$-3.0000$

2.2100

$-2.2400$

$-2.2500$

$-2.3500$

.

$-2.1800$

$-2.3500$

$-2.8900$
-1.3200

-1.2700
-0.4280

0.7790

$-0.1780$

$-0.3260$

$-0.7460$

0.6410

0.9540

$-0.0890$

0.4000

0.9840

0.8600

-0. 0600

$-0.1200$

$-1.0200$

1. 0600

$-0.9300$

$-0.8700$

$-0.8700$

$-0.9100$

0.6900

0.3700

$-1.1300$

$-2.2900$

2.1300

$-0.8100$

$-0.8700$

$-1.2200$

$-0.5700$

$-0.3000$

0.5000

$-0.9800$

$-3.0300$

$-2.3700$

$-1.7100$

.

$-1.1000$

$-0.5600$

$-1.3500$
DOLDMITE

$\operatorname{LOG}(0 / K)$

$-1.7570$

-2.1430
-1.2140

2. 4360

-0.0490

-0.0140
-0.7470

0.7470

2. 1080

2.7580

0.7720
1.0230

1.6480

2.6280

$-1.1600$

0.4400

0.3400

$-1.5200$

$-2.3800$

1.5400

$-1.6500$

- 1.1900

$-1.4200$

$-1.1500$

1.0800

$-0.6500$

$-1.9600$

$-4.0600$

$-3.4800$

$-1.6500$

$-1.7200$

$-2.6800$

$-0.6500$

0.0030

- 1.1200

-1.1200
1. 1100

.

$-2.3000$

$-4.3200$

$-2.8000$

.

$-1.8800$

$-0.6200$ 
CALCITE LOG(Q/K)

20, U12E

21. U12E. 04

22. U12E.03

23, U12E

24, U12E.02

25. U12E. OS

26. U12E.O3

27. U12E.O3

29. U12E. 07

30. U12E

31. U $12 E$

32. U12E

33, U12E

34, U12B

35. U128.03

36, U12.04

SEEP 2; U12N.O3

SEEP 3. U12N.05

SEEP 4 U12N.03

LYSIMETER 1.U12N.05

LYSIMETER 2 U12N.05

LYSIME TER 3, U12N. OS

I.YSIMETER 4, U12N.05

LYSIMETER 5, U12N:05

LYSIMETER 6. SURF SOIL

LYSIMETER 7. SURF SOIL

LYSIMETER 9, SURF SOIL

ANAL 2589. TUNNEL U12B. E

ANAL 2819. TUNNEL U12B.

ANAL 3260, TUNNEL U12E: D

ANAL 3541, TUNNEL U12E, M

$N=193$

$-2.1200$

$-2.6200$

$-1.6600$

$-2.5900$

$-2.3400$

$-1.8800$

2.7500

$-2.3100$

2.7900

$-1.9220$

$-1.7510$

$-2.2330$

$-1.0400$

$-1.0400$

$-1.7480$

1. 7450

$-1.7450$

$-2.4390$

$-2.2300$

$-2.1340$

$-2.7500$

$-2.3100$

$-2.6900$

$-2.6500$

$-2.9400$
14:5O THURSDAY, MAY 29, 198632

DOLOMITE

$\operatorname{LOG}(0 / K)$
$-1.6200$

-1.6200
-0.5600

$-1.9200$

$-0.6700$

$-1.7400$

$-1.2860$

$-2.2950$

$-1.6310$

$-2.3430$

$-0.7740$

$-1.9480$

$-1.7530$

$-1.9490$

$-3.2950$

$-1.4990$

$-0.5120$

$-0.6700$

$-1.7500$

$-1.7900$

$-2.9500$

$-1.6400$
$-0.7700$

$-1.3300$

$-3.1800$

$-4.4750$

$-3.8290$

$-1.9180$

$-4.1930$

$-4.0190$

$-4.2550$

$-5.6200$

$-2.4780$

$-0.5360$

$-1.0400$

$-3.1700$ 


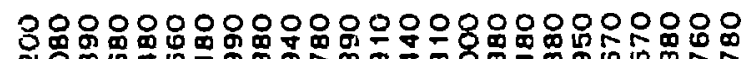

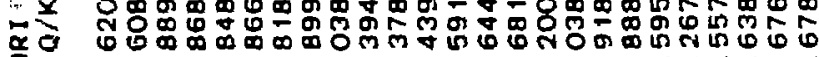

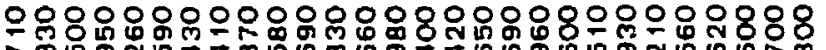

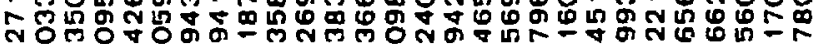

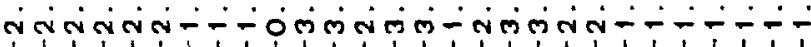


SITE

$48,165 / 48 E-18 B C C$

$49,165 / 48 E-17 C C C$

50, 16S/48E - 18DAD

51. $165 / 48 E-8 C D A$

52. $165 / 48 E-17 A B B$

62. WHITEROCK SPRING

68, BUTTE SPRING

70, OAK SPRING

71. TOPOPAH SPRING

1. $10 S / 47 \mathrm{E}-14 \mathrm{BAB}$

2 , 1OS/47E-27CBA

3 , $105 / 47 E-3$ 1AAB

4. $105 / 47 E-32 D D A$

5. 1OS/47E-33AAB

6. $105 / 47 E-30 D C C$

7. $115 / 46 E-26 B B B$

8. $10 S / 46 E-26 B C C$

9 , 1 15/47E-3CDB

10, $115 / 47 E-4 C A D$

11. 11S/47E- 1OCAA

12. $14 S / 47 E-1 O B C C$

13. 11S/47E-16DCD

14. 11S/47E-16BDC

15. 11S/47E- $18 A C D$

16. 11S/47E $-21 A C C$

17. 1IS/47E-2 1DBB

18, $11 \mathrm{~S} / 47 \mathrm{E}-21 \mathrm{ABA}$

19, 11S/47E-21ABA

20. 1 IS/47E-27CBA

21. 115/47E-2BBA

22 IIS/47E-2BDAC

22. 1IS/47E-28DAC

23. 1IS/47E-33BAC

24. 11S/47E- 1OCCB

25, 12S/47E-5CDA

$26,125 / 47 E-6 C D D$

27. $125 / 47 E-7 D B D$

$28,12 S / 47 C-2 O B B B$

$29,125 / 47 E-19 A D C$

18B, $125 / 47 E-20$

$19 \mathrm{~B}, \quad 12 \mathrm{~S} / 47 \mathrm{E}-20$

$20 B, 12 S / 47 E-20$

21B 12S/47E-20

$22 B, 12 S / 47 E-20$

WELL UE-19B-1

WELL UE-19C

WELL UE-19D

WELL UE-19E

WELL UE-19E

WELL UE-19GS

WELL UE-19GS

WELL U-2OA-2

WELL U-2OA-2

WELL. UE-2OD
GYPSUM LOG(Q/K)

$-1.2600$

$-1.1100$

$-1.2700$

$-1.3200$

$-1.2400$

.

$-2.358 n$

1.7210

•

$-1.9560$

$-1.7120$

.

$\cdot$

$-1.6950$

1.9880

$-2.1460$

-

$-1.6800$

$-1.5720$

:

.

$-2.3340$

$-4.9970$

$-1.7300$

$-3.1800$

$-2.9480$

$-2.7700$

$-2.7570$
MAGNESI TE $1.0 G(\mathrm{D} / \mathrm{K})$

0.4700

0.8400

$-0.9300$

-1.1100
-1.2000

$-2000$

$-1.9510$

1. 1450

.

$-1.4560$

$-1.1050$

.

$-1.0300$

$-1.8480$

0.2670

.

$-1.0510$

$-1.1590$

-1.1590
.

$-1.7210$

$-2.1760$

$-0.6220$

$-2.3930$

$-2.0900$

$-3.0090$

$-2.4870$
FLUOR I TE

L.OG $(Q / K)$

0.4430

$-0.3020$

.

$-0.3630$

o. 3050

0.2720

0.0030

$-0.0030$

.

$-1.8310$

0.4500

.

$-0.0740$

$-0.1580$

0.4780

$-0.4460$

$-1.1790$

$-0.7560$

$-1.0410$ 
GYPSUM LOG(O/K)

-4.1090
-3.7350
-1.4180
-1.8260
-3.2610
-2.5090
-3.7210
-1.6130
-1.6340
-2.5080
-2.5120
-2.2810
-1.8280
-2.6200
-2.0900
-2.1000
-2.1700
-2.2200
-1.8100
-2.3300
-2.0900
-2.7200
-2.3800
-2.1100
-1.9300
-2.1600
-2.6900
-4.3100
-4.1500
-3.1600
-3.2600
-3.4400
-2.7600
-2.5200
-3.3500
-2.8900
-2.4300
.

MAGNESITE $\operatorname{LOG}(0 / K)$

GELL UE-20E-1

WELL UE-2OH

WELL UE-20J

WELL ARMY-1

WELL 5A

WELL 5B

WELL $C$

WELL $c-1$

WELL 3

WELL A 2

WELL UE-15D

UE $12 T H 3-5,134,4(M)$

UE 12TH3-6, 169.6(M)

UE 12TH3-7, 199.2(A)

UE 12TH3-B, 202 . 4 (M)

UE 12TH3-9, 257 G(M)

UE $12 T H 3-11,441.4(\mathrm{M})$

UE 12TH3-11, 441.4(M)

UE 12TH3-12, 442.4 (M)

UE 2 TH-14: $320.3(M)$

UE 12TH3-15; 320.6(M)

UE 12TH3-16, 321.3(M)

UE 12TH3-17, 350. $\mathrm{g}(\mathrm{M})$

UE 12TH3-18, 411.2(M)

UE 12TH3-19, 470.6(M)

UE 12TH3-20, 472.4(M)

UE 12TH3-21, 501. $7(\mathrm{~m})$

UE 12T $\# 3-22,503.2(M)$

UE 12 T $\$ 3-23,532$. B(M)

RML 1A. SURFACE

RML 1B, SURFACE

1. U12N.O5 BYPASS

2. U12N.05

3. U12N.05

4. U12N MAIN

5. U12N.07 BYPASS

6. U12N.02

7. U12T.02 BYPASS

B. U12T.02

9. U12T.02 BYPASS

10. U12T MAIN

11. U12T.03

12. U12T.03

13. U12T.04

14. U12T.03

15. U12T.03

16. U12T. 03

17. U12E. 07

1B. U12E. 04

19. U12E
$-2.0200$

$-2.4590$

$-2.3350$

0.0640

$-1.5110$

$-1.3170$

- 1.6330

0.2510

$-0.7890$

$-0.7620$

$-0.3250$

0.0710

$-1.9200$

$-1.1300$

$-1.1300$

$-2.1300$

$-2.1100$

$-2.5300$

2.

- 1.9500

$-2.1400$

2. 1000

- 0.9200

$-1.7700$

$-2.4600$

$-3.3900$

$-2.9700$

$-2.4700$

$-2.4800$

$-1.7400$

1. 3300

- 1.3300

. 9200

$-2.2600$

$-1.0300$

$-2.9500$

$-3.5700$

$-2.2700$

.

$2: 4000$

$-1.6800$
FLUDRITE

$\operatorname{LOG}(0 / K)$

$-1.9030$

$-1.82 B 0$

$-0.3290$

$-0.9490$

$-1.3180$

- 1.9180

$-2.6520$

$-0.7900$

-0.9050
-1.2170

-1.2170
-1.5790

$-1.8640$

-1.8610
-0.6110 
SA 5

SITE

20. U12E

21. U12E. 04

22. U12E.03

23. UT2E

24. U12E. 02

25: U12E. 05

26. U12E.03

27, U12E.03

28. U12E.03

29. U12E.

31. U12E

32. U12E

32. U12E

33. U12E

35, U12B.03

36. U12.04

SEEP $1, U 12 T$

SEEP 2. U12N.03

SEEP 3. U12N.05

SEEP $4, U 12 N .03$

LYSIMETER 1, U12N.05

LYS IMETER 2, U12N. 05

LYSIMETER 3, U12N.05

LYSIMETER 4. U12N.05

LYSIMETER 5 , U12N.05

LYSIMETER G: SURF SOIL

LYSIMETER 7; SURF SOIL

LYSIMETER 7. SURF SOIL

ANAL 2589, TUNNEL U12B, E

ANAL 2589, TUNNEL U12B, E

ANAL 2819, TUNNEL U128. D

ANAL 2913. TUNNEL U12E. D

ANAL 3260, TUNNEL U12E, D

$N=\quad 193$
GYPSUM $\operatorname{LOG}(Q / K)$

.
-3.7600
-3.4700
.
-3.6600
-2.6000
-3.1900
.
-2.7700
-3.0000
-3.6170
-3.3700
-2.7030
-3.8900
-3.4720
-4.0940
-3.5530
-3.5200
-5.1980
-3.7120
-2.5950
-2.7600
-3.0200
-3.4900
-4.7800
-3.4800

MAGNES I TE

$\operatorname{LOG}(Q / K)$

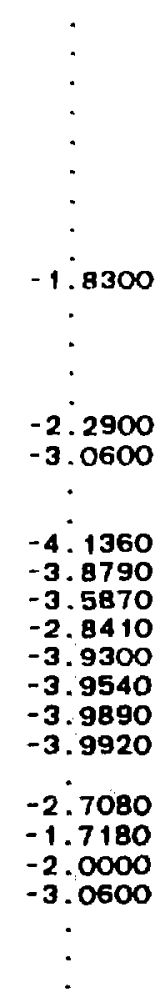

14:50 THURSDAY, MAY 29, 198636 FLUORI TE

$\operatorname{LOG}(0 / K)$

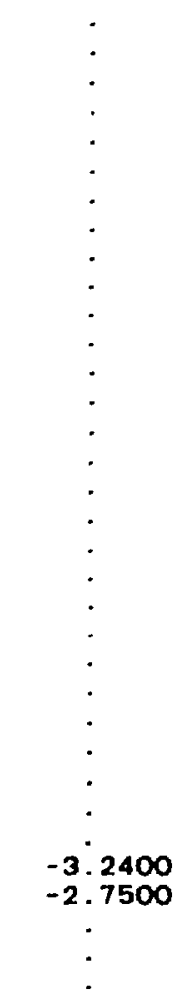




\author{
APPENDIX B \\ IMPORTANCE OF RADIONUCLIDE TRANSPORT \\ BY PARTICULATES ENTRAINED IN FLOWING GROUNDWATERS
}

Allen Ogard

\title{
INTRODUCTION
}

The Nevada Nuclear Waste Storage Investigations Project of the US Department of Energy is studying the suitability of Yucca Mountain (Nye County, Southern Nevada: as a potential repository for high-level nuclear waste. The possibility that flowing groundwaters in this area might transport potentially hazardous radionuclides or other harmful elements (both hereafter referred to as waste elements) from a waste repository to the accessible environment requires careful evaluation, and a considerable amount of study is currently being devoted to understanding this potential problem. Leached waste elements could potentially migrate as dissolved species with the groundwater, but it is also conceivable that particulates (perhaps small mineral fragments from tuffs) or natural colloids (that is, iron hydroxide) moving with the groundwaters could strongly sorb various waste species and transport these elements through fractures or open matrix porosity. The intent of this appendix is to qualitatively assess the potential of any particulates that may be entrained in flowing groundwaters to transport important quantities of sorbed wa:te elements as these groundwaters migrate through the Yucca Mountain environment.

EXPERIMENT AND RESULTS

Well $\mathrm{J}-13$ is the closest well to Yucca Mouritain from which groundwater is being routinely pumped, and is located approximately 4 miles to the southeast of the crest of Yucca Mountain, on the east side of Fortymile Wash. As J-13 may intersect groundwater flow paths from the candidate repository site to the accessible environment, water from this well was chosen for particulate content studies. Water was diverted from the well into a moblle laboratory containing filtration equipment at a rate of approximately $1 \mathrm{l} / \mathrm{min}$. A prefilter which removes material larger than $10 \mu \mathrm{m}$ from the water was positioned upstream from a large stainless steel One-Sevener Nuclepore Membrane Filter Assembly which was normally loaded with seven $0.4 \mu \mathrm{m}$ membrane filters, mounted in parallel. 
Approxinately one half of the water discharged from this assembly subsequently passed through an Amicon Hollow Fiber Filter system which removes particulates with diameters greater than $\sim 5 \mathrm{~nm}$.

A filtration run was condicted for 14 days, during which time $9300 \ell$ of water were passed through the $0.4 \mu \mathrm{m}$ membrane filters, and $5300 \mathrm{\ell}$ through the $5 \mathrm{~nm}$ hollow fiber system. The material collected on the membrane filters was removed by ultrasonic treatment in a small quantity of Nanopure water, and the resulting suspension was centrifuged at $10,000 \mathrm{rpm}$ for 20 minutes. The liquid was then decanted and discaried, and the sediment was washed with ethyl alcohol and allowed to dry in air. A total of $0.25 \mathrm{~g}$ of solid material was thus ootained which, when divided by the quantity of water that was filtered, corresponds to a sediment concentration of $\sim 2.7 \times 10^{-5} \mathrm{~g} / \ell$. This particulate fraction was dissolved in a mixture of $\mathrm{HNO}_{3}, \mathrm{HCl}$ and $\mathrm{HF}$ acids, and the solution was then diluted and analyzed. The particulates collected by the hollow fiber system were removed by backflushing with the minimum amount of Nanopure water and were subsequently analyzed in solution. It was calculated frowi the concentrations of species in the two solutions that the amount of material in the smaller-size particulate fraction was only about $1 \%$ that in the larger-size fraction.

Both solutions were analyzed for cation composition by means of emission spectroscopy. The detectable cations in the $>0.4 \mu \mathrm{m}$ fraction were (in wt\%) Si(60), $\mathrm{Fe}(20), \mathrm{Ca}(11)$ and $\mathrm{Al}(4)$, while analysis of the smaller-sized fraction gave somewhat different results: $\mathrm{Na}(44), \mathrm{Si}(42), \mathrm{Ca}(8)$, and $\mathrm{Fe}(4)$, with no detectable $\mathrm{Al}$. Because the amount of $\mathrm{Fe}$ in the Yucca Mountain tuffs and groundwaters is very low, it is possible that the iron-rich particulates (and perhaps others) could have been contamination from the steel piping and pumping systems. However, as we wish to make a conservative assessment of the importance of particulates in waste element transport, we will assume that all recovered particulates are natural and were originally entrained in the groundwater pumped from $3-13$.

OISCUSSION AND CONCLUSIONS

To assess the importance of particulates in the transport of waste elements, we need to determine the amount of a given species that is sorbed on particulates, and compare this quantity to the amount which is dissolved in the groundwater. Let 
$\begin{aligned} & R_{d}= \text { sorption ratio }=\frac{\text { moles of particulate-sorbed species } / \mathrm{g} \text { of particulate }}{\text { moles dissolved species/ml of groundwater }} \\ & \text { [units of } \mathrm{ml} / \mathrm{g} \text { ] }\end{aligned}$

$x=$ concentration of species-sorbing particulates in groundwater [units of $g / l$ ]

$c=$ concentration of species dissolved in groundwater [units of moles/l]

For the purposes of this simple analysis we will assume the system attains steady state, and that particulate surface area and ground water chemistry effects, etc. can be neglected. From the above then,

$y=$ moles of particulate-sorbed species $/ g$ of particulate $=\frac{R_{d} \bullet C}{1000}$ and

$z=$ moles of particulate-sorbed species/liter groundwater $=y \bullet x$.

Therefore, to determine the relative distribution of waste elements between sorbed and dissolved species, we need only examine the ratio $z / c$, which from above is also equal to $R_{d} x / 1000$.

Figure $B-1$ is a plot of the sorption ratio, $R_{d}$, versus the groundwater particulate concentration, $x$, and shows a trajectory for the value of $z / c=0.1$. This value has been arbitrarily chosen, and implies that the quantity of species sorbed on particulates is only $10 \%$ of that dissolved in the groundwater. The value of $c$ in groundwater can range anywhere from essentially zero to the solubility limit of the species, and as concentrations are frequently not known to better than an order to magnitude, an additional contribution of $10 \%$ to the total waste element concentration because of the presence of particulate-sorbed species, should constitute a negligible source of error. Examination of Fig. B-1, therefore, indicates that for any combination of $R_{d}$ and $x$ lying below the $z / c=0.1$ line (that is, particulates sorb less than $10 \%$ of the total species), transport of waste elements as sorbed species on particulates entrained in flowing groundwater should be of little consequence as the bulk of the waste element will be present as dissolved species. This is actually a very conservative analysis in that we are assuming that the particulate velocity is essentially equal to the groundwater velocity. In reality, particulate transport is a strong function 
of size (among other things) and is probably very significantly retarded relative to the groundwater flux for the bulk of the entrained particulates.

As determined above, the approximate concentration of $>0.4 \mu \mathrm{m}$ particulates in $\mathrm{j}-13$ water was $2.7 \times 10^{-5} \mathrm{~g} / \mathrm{l}$. Examination of $\mathrm{Fig} . \mathrm{B} \cdot 1$ indicates that these particulates would have to exhibit a sorption ratio greater than $\sim 4 \times 10^{6} \mathrm{ml} / \mathrm{g}$ for the specles of interest in order for particulates to contribute more that $10 \%$ to the total waste element flux. The smaller-sized particulate fraction would have to exhibit sorption ratios greater than $\sim 4 \times 10^{8} \mathrm{m \ell} / \mathrm{g}$ to have a similar effect. These sorption ratios are extremely high and have seldom even been approached in sorption experiments using Yucca Mountain tuffs. However, no sorption ratios have ever been directly determined for the particulates, and it may be possible that they would exhibit sorption ratios of this magnitude or even higher; this is considered highly unlikely as the particulates are probably directly derived from Yucca Mountain tuffs and would be expected to yield similar sorption ratios. To assess this possibility, additional quantities of particulates have been collected from J-13, and we will attempt to experimentally determine sorption ratios for these materials in the future.

Considerably more work would be needed to quantitatively establish the particulate-sorbed contribution to total radionuclide transport. Particulate concentrations, sorption ratios, relative transport velocities, etc., would need to be determined at a number of locations along representative groundwater flow paths to arrive at a more realistic assessment of sorbed-radionuclide fluxes at Yucca Mountain. However, based on the above analysis, and considering the conservative assumptions employed throughout, it can probably be safely assumed that the transport of particulate-sorbed radionuclides by groundwater flow will constitute a negligible component of the total waste element flux at Yucca Mountain. It is highly probable that dissolved species or natural colloids will comprise a much more important component of the overall flux. 


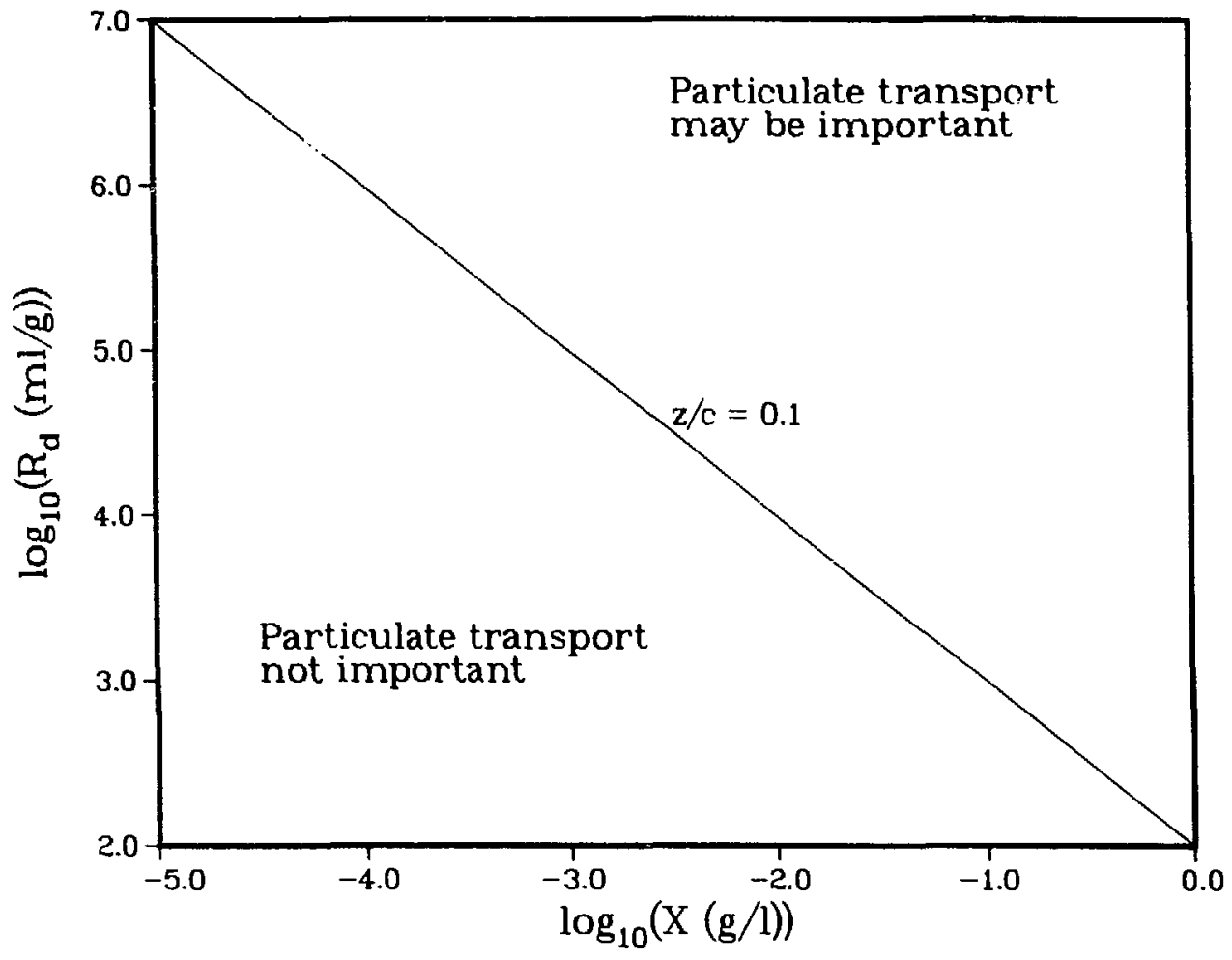

Fig. B-1. Relative importance of particulate-sorbed vs dissolved waste element transport as a function of sorption ratio and particulate concentration. $z / c=0.1$ implies that $10 \%$ of the total amount of waste element present is sorbed, and $90 \%$ is dissolved. 